\title{
REPORT ON THE PREDATION INDEX, PREDATOR CONTROL FISHERIES, AND PROGRAM EVALUATION FOR THE COLUMBIA RIVER BASIN EXPERIMENTAL NORTHERN PIKEMINNOW MANAGEMENT PROGRAM
}

\section{ANNUAL REPORT}

\author{
Prepared by: \\ Russell Porter \\ Pacific States Marine Fisheries Commission \\ In Cooperation with: \\ Oregon Department of Fish and Wildlife \\ Washington Department of Fish and Wildlife \\ U.S. Department of Agriculture
}

Prepared for:

U.S. Department of Energy

Bonneville Power Administration

Environment, Fish and Wildlife

P.O. Box 3621

Portland, OR 97208-3621

Project Number 199007700

Contract Number 00026763 


\section{Table of Contents}

Executive Summary

Report A - Sport Reward Fishery in the Columbia and Snake Rivers 10

$\begin{array}{ll}\text { Abstract } & 11\end{array}$

$\begin{array}{ll}\text { Introduction } & 12\end{array}$

Methods of Operation $\quad 13$

$\begin{array}{ll}\text { Fishery Operation } & 13\end{array}$

Boundaries and Season $\quad 13$

Registration Stations $\quad 14$

Reward System 14

Angler Sampling $\quad 15$

Returning Anglers 16

Non-Returning Anglers $\quad 16$

Northern Pikeminnow Handling Procedures $\quad 17$

Biological Sampling $\quad 17$

PIT Tag Detection $\quad 17$

Northern Pikeminnow Processing 18

$\begin{array}{ll}\text { Results and Discussion } & 18\end{array}$

Northern Pikeminnow Harvest 18

Harvest by Week 19

Harvest by Fishing Location $\quad 20$

Harvest by Registration Station $\quad 21$

Harvest by Species/Incidental Catch $\quad 22$

Angler Effort $\quad 24$

Effort by Week 25

Effort by Fishing Location $\quad 27$

Effort by Registration Station $\quad 27$

Catch Per Angler Day (CPUE) 28

CPUE by Week 29

CPUE by Fishing Location $\quad 30$

CPUE by Registration Station $\quad 30$

$\begin{array}{ll}\text { Angler Totals } & 31\end{array}$

Tag Recovery $\quad 34$

Northern pikeminnow tags 34

Ingested Tags $\quad 35$

Summary 38

Recommendations for the 2009 Season 39

$\begin{array}{ll}\text { Acknowledgments } & 40\end{array}$ 
Report B - Sport Reward Payments - $2008 \quad 45$

$\begin{array}{ll}\text { Introduction } & 46\end{array}$

$\begin{array}{ll}\text { Catch and Payments } & 46\end{array}$

$\begin{array}{ll}\text { Tagged Fish Payments } & 46\end{array}$

$\begin{array}{ll}\text { Tournament Drawings } & 46\end{array}$

$\begin{array}{lr}\text { Accounting } & 47\end{array}$

2008 Sport Reward Payments Summary $\quad 48$

Report C - Indexing and Fisheries Evaluation 49

$\begin{array}{lr}\text { Summary } & 50\end{array}$

$\begin{array}{ll}\text { Introduction } & 51\end{array}$

Methods $\quad 51$

Fishery Evaluation, Predation Estimates, and Tag Loss 51

Biological Evaluation $\quad 55$

Results $\quad 58$

Fishery Evaluation, Predation Estimates, and Tag Loss 58

$\begin{array}{ll}\text { Biological Evaluation } & 61\end{array}$

$\begin{array}{ll}\text { Discussion } & 70\end{array}$

$\begin{array}{ll}\text { Acknowledgments } & 75\end{array}$

$\begin{array}{ll}\text { References } & 76\end{array}$

Appendix A. Sampling Effort and Timing in the Lower Columbia and $\begin{array}{ll}\text { Snake Rivers } & 81\end{array}$

Appendix B. Exploitation Rates for Northern Pikeminnow 84

Appendix C. Biological Evaluation of Northern Pikeminnow, Smallmouth Bass, and Walleye in the Lower Columbia and Snake Rivers, 1990-2008

Report D - Dam Angling Test Fishery - $2008 \quad 97$

$\begin{array}{ll}\text { Methods } & 98\end{array}$ 
Manpower

98

Fishing location

98

Angler Techniques/gears

98

Results

99

Discussion

100

Suggestions for future operations

100 


\title{
2008 Executive Summary
}

by

\author{
Russell G. Porter
}

This report presents results for year seventeen in the basin-wide Experimental Northern Pikeminnow Management Program to harvest northern pikeminnow ${ }^{1}$ (Ptychocheilus oregonensis) in the Columbia and Snake Rivers. This program was started in an effort to reduce predation by northern pikeminnow on juvenile salmonids during their emigration from natal streams to the ocean. Earlier work in the Columbia River Basin suggested predation by northern pikeminnow on juvenile salmonids might account for most of the $10-20 \%$ mortality juvenile salmonids experience in each of eight Columbia River and Snake River reservoirs. Modeling simulations based on work in John Day Reservoir from 1982 through 1988 indicated that, if predator-size northern pikeminnow were exploited at a $10-20 \%$ rate, the resulting restructuring of their population could reduce their predation on juvenile salmonids by $50 \%$.

To test this hypothesis, we implemented a sport-reward angling fishery and a commercial longline fishery in the John Day Pool in 1990. We also conducted an angling fishery in areas inaccessible to the public at four dams on the mainstem Columbia River and at Ice Harbor Dam on the Snake River. Based on the success of these limited efforts, we implemented three test fisheries on a system-wide scale in 1991 - a tribal longline fishery above Bonneville Dam, a sport-reward fishery, and a dam-angling fishery. Low catch of target fish and high cost of implementation resulted in discontinuation of the tribal longline fishery. However, the sportreward and dam-angling fisheries were continued in 1992 and 1993. In 1992, we investigated the feasibility of implementing a commercial longline fishery in the Columbia River below Bonneville Dam and found that implementation of this fishery was also infeasible.

Estimates of combined annual exploitation rates resulting from the sport-reward and damangling fisheries remained at the low end of our target range of $10-20 \%$. This suggested the need for additional effective harvest techniques. During 1991 and 1992, we developed and tested a modified (small-sized) Merwin trapnet. We found this floating trapnet to be very effective in catching northern pikeminnow at specific sites. Consequently, in 1993 we examined a systemwide fishery using floating trapnets, but found this fishery to be ineffective at harvesting large numbers of northern pikeminnow on a system-wide scale.

In 1994, we investigated the use of trap nets and gillnets at specific locations where concentrations of northern pikeminnow were known or suspected to occur during the spring season (i.e., March through early June). In addition, we initiated a concerted effort to increase public participation in the sport-reward fishery through a series of promotional and incentive activities.

1 The common name of the northern squawfish was recently changed by the American Fisheries Society to northern pikeminnow at the request of the Confederated Tribes and Bands of the Yakama Indian Reservation. 
In 1995, 1996, and 1997, promotional activities and incentives were further improved based on the favorable response in 1994. Results of these efforts are subjects of this annual report.

Evaluation of the success of test fisheries in achieving our target goal of a 10-20\% annual exploitation rate on northern pikeminnow is presented in Report $\mathrm{C}$ of this report. Overall program success in terms of altering the size and age composition of the northern pikeminnow population and in terms of potential reductions in loss of juvenile salmonids to northern pikeminnow predation is also discussed in Report $\mathrm{C}$.

Program cooperators include the Pacific States Marine Fisheries Commission (PSMFC), Oregon Department of Fish and Wildlife (ODFW), and Washington Department of Fish and Wildlife (WDFW), and the U. S. Department of Agriculture (USDA), Animal Damage Unit as a contractor to test Dam Angling. The PSMFC was responsible for coordination and administration of the program; PSMFC subcontracted various tasks and activities to ODFW and WDFW based on the expertise each brought to the tasks involved in implementing the program and dam angling to the USDA. Objectives of each cooperator were as follows.

1. WDFW (Report A): Implement a system-wide (i.e. Columbia River below Priest Rapids Dam and Snake River below Hells Canyon Dam) sport-reward fishery and operate a system for collecting and disposing of harvested northern pikeminnow.

2. PSMFC (Report B): Provide technical, contractual, fiscal and administrative oversight for the program. In addition, PSMFC processes and provides accounting for the reward payments to participants in the sport-reward fishery.

3. ODFW (Report C): Evaluate exploitation rate and size composition of northern pikeminnow harvested in the various fisheries implemented under the program together with an assessment of incidental catch of other fishes. Estimate reductions in predation on juvenile salmonids resulting from northern pikeminnow harvest and update information on year-class strength of northern pikeminnow.

4. USDA (Report D): Dam angling at The Dalles and John Day dams.

Background and rationale for the Northern Pikeminnow Management Program can be found in Report A of our 1990 annual report (Vigg et al. 1990). Highlights of results of our work in 2008 by report are as follows: 


\section{Report A}

\section{Implementation of the Northern Pikeminnow Sport-Reward Fishery in the Columbia and Snake Rivers}

1. Objectives for 2008 were to: (1) implement a recreational fishery that rewards recreational anglers for harvesting northern pikeminnow $\geq 228 \mathrm{~mm}$ (9 inches) total length (TL), (2) collect, compile, and report data on angler participation, catch and harvest of northern pikeminnow and other fish species, as well as success rates of participants during the season, (3) examine collected northern pikeminnow for the presence of external tags, fin clips, and signs of tag loss, (4) collect biological data on northern pikeminnow and other fish species returned to registration stations, (5) scan northern pikeminnow for the presence of consumed salmonids containing Passive Integrated Transponder (PIT) tags, and (6) survey non-returning NPSRF participants targeting northern pikeminnow in order to obtain catch and harvest data on fish species caught, and (7) examine and process all northern pikeminnow caught by U.S. Department of Agriculture (USDA) angling crews operating at The Dalles and John Day dams to recover spaghetti and/or PIT tags.

2. The NPSRF was conducted from May 5 through October 12, 2008. Seventeen registration stations were operated throughout the lower Snake and Columbia rivers.

3. A total of 159,806 northern pikeminnow $\geq 9$ inches in total length were harvested during the 2008 season with 26,141 angler days spent harvesting these fish. Catch-per-anglerday for all anglers during the season was 6.11 fish.

4. Anglers submitted 167 northern pikeminnow with external tags, and an additional 123 with Pit Tags only, along with possible tag wounds and/or fin clips, but without spaghetti tags. A total of 107 salmonid PIT tags from consumed juvenile salmonids were detected in the pikeminnows caught, and the codes recorded for transmittal to the PITAGIS database.

\section{Report B}

\section{Northern Pikeminnow Sport-Reward Fishery Payments}

1. For 2008 the rewards paid to anglers were the same as in the 2007 season. Anglers were paid $\$ 4, \$ 5$, and $\$ 8$ per fish for the three payment tiers (up to 100 fish, 101-400 fish and 401 and up) during the season. The rewards for a tagged fish were $\$ 500$ per fish.

2. During 2008, excluding tagged fish, rewards paid totaled $\$ 1,001,693$ for 158,674 fish.

3. A total of 167 tagged fish vouchers were paid. The total season tag rewards paid totaled $\$ 83,500$.

4. A total of 994 separate successful anglers received payments during the season. 
5. A special one-month tournament was held in August to promote more fishing effort. Twenty anglers received prizes of $\$ 2,000$ each for a total payout of $\$ 40,000$.

6. The total for all payments for non-tagged and tagged pikeminnows in 2008 was $\$ 1,125,193$.

\section{Report C}

\section{Development of a Systemwide Predator Control Program: Indexing and Fisheries Evaluation}

1. Objectives in 2008 were to (1) evaluate northern pikeminnow exploitation, potential predation, and tag loss, (2) define population parameters of northern pikeminnow, smallmouth bass Micropterus dolomieu, and walleye Sander vitreus below Bonneville and in Bonneville reservoir, and (3) look for possible compensatory responses by these species

2. System-wide exploitation in 2008 of northern pikeminnow $200 \mathrm{~mm}$ or greater in fork length was $14.8 \%$ which incorporated a tag loss of $5.0 \%$. Sport-reward exploitation of fish $\geq 250 \mathrm{~mm}$ FL was $19.5 \%$, the highest exploitation rate since program inception.

3. The 2008 estimated reduction in potential predation was estimated at $62 \%$ of pre-program levels. This is one percent greater than last year, but a $13 \%$ reduction than observed previously ( $75 \%$; Jones et al. 2005), and is related to the updates we have made in the predation model.

4. Biological indexing was conducted in the lower Columbia River as part of our predator community evaluation. Northern pikeminnow abundance indices in Bonneville Reservoir and below Bonneville Dam continued a downward trend and were the lowest observed to date. Although $45 \%$ of northern pikeminnow stomachs were empty, 124 samples contained identifiable fish remains, of which $69 \%$ were identified as juvenile salmonids. Predation indices varied this year by location and season. Relative weights of northern pikeminnow are slightly up in 2008 and year-class analyses show variation from year to year in the percentage of age 3 and 4 fish.

5. Northern pikeminnow stock density indices appear to be fluctuating in habitats below Bonneville Dam and in Bonneville Reservoir. The observed increasing trend in the proportional stock density may indicate that there is change occurring in the way the population is functioning. Proportional stock densities measured in 2008 were similar to those observed in 1990, which may imply that larger northern pikeminnow are rebounding. Proportional stock density values in 2008 may also be related to lower abundance index values. 


\section{Report D}

\section{Dam angling at The Dalles and John Day dams}

1. A five man fishing crews was utilized to fish from May 5, 2008 through August 15, 2008 at The Dalles and John Day dams.

2. Fishing for 1080 hours at The Dalles dam resulted in 1,400 northern pikeminnow caught, of which 0 were tagged fish.

3. Fishing for 1,005 hours at John Day dam resulted in 2,428 northern pikeminnow caught, of which 1 was a tagged fish.

Fishing success was best the first couple hours in the morning and some good success right before dark. Overall the spill at the dams had a considerable negative effect on fishing efforts this year. Cold water and high flows made fishing tough. Fishing times were adjusted to various periods, but the 24 hour spill made fishing hard. 


\title{
Report A
}

Implementation of the Northern Pikeminnow Sport-Reward Fishery in the Columbia and Snake Rivers

Prepared by:

\author{
Eric C. Winther \\ John D. Hone \\ Paul V. Dunlap \\ Kathleen C. Moyer
}

Washington Department of Fish and Wildlife

600 Capitol Way N., Olympia, WA 98501-1091

March, 2009 


\begin{abstract}
We are reporting on the progress of the Northern Pikeminnow Ptychocheilus oregonensis SportReward Fishery (NPSRF) implemented by the Washington Department of Fish and Wildlife (WDFW) on the Columbia and Snake Rivers from May 5 through September 28, 2008. The objectives of this project were to (1) implement a recreational fishery that rewards recreational anglers for harvesting northern pikeminnow $\geq 228 \mathrm{~mm}$ (9 inches) total length (TL), (2) collect, compile, and report data on angler participation, catch and harvest of northern pikeminnow and other fish species, as well as success rates of participants during the season, (3) examine collected northern pikeminnow for the presence of external tags, fin clips, and signs of tag loss, (4) collect biological data on northern pikeminnow and other fish species returned to registration stations, (5) scan northern pikeminnow for the presence of consumed salmonids containing Passive Integrated Transponder (PIT) tags, and (6) survey non-returning NPSRF participants targeting northern pikeminnow in order to obtain catch and harvest data on fish species caught, and (7) examine and process all northern pikeminnow caught by U.S. Department of Agriculture (USDA) angling crews operating at The Dalles and John Day dams to recover spaghetti and/or PIT tags.
\end{abstract}

A total of 159,806 northern pikeminnow $\geq 228 \mathrm{~mm}$ and 3,507 pikeminnow $<228 \mathrm{~mm}$ were harvested during the 2008 NPSRF season. There were a total of 3,610 different anglers who spent 26,141 angler days participating in the fishery. Catch per unit effort for combined returning and non-returning anglers was 6.11 fish/angler day. The Oregon Department of Fish and Wildlife (ODFW) estimated that the overall exploitation rate for the 2008 NPSRF was $19.5 \%$.

Anglers submitted 167 northern pikeminnow with external spaghetti tags, of which there were 166 with both spaghetti and PIT tags. There were also 123 northern pikeminnow with PIT tags only, along with possible tag wounds and/or fin clips, but without spaghetti tags. A total of 107 PIT tags from consumed juvenile salmonids were detected and interrogated from northern pikeminnow received during the 2008 NPSRF.

Peamouth Mylocheilus caurinus, smallmouth bass Micropterus dolomieue, walleye Stizostedion vitreum vitreum, yellow perch Perca flavescens, and channel catfish Ictalurus punctatus were the fish species most frequently harvested by NPSRF anglers targeting northern pikeminnow. The incidental catch of salmonids Oncorhynchus spp, by participating anglers targeting northern pikeminnow remained below established limits for the Northern Pikeminnow Management Program. 


\section{INTRODUCTION}

Mortality of juvenile salmonids Oncorhynchus spp. migrating through the Columbia River system is a major concern of the Columbia Basin Fish and Wildlife Program, and predation is an important component of mortality (NPPC 1987a). Northern pikeminnow Ptychocheilus oregonensis, formerly known as northern squawfish (Nelson et al. 1998), are the primary piscine predator of juvenile salmonids in the Lower Columbia and Snake River Systems (Rieman et al. 1991). Rieman and Beamesderfer (1990) predicted that predation on juvenile salmonids could be reduced by up to $50 \%$ with a sustained exploitation rate of $10-20 \%$ on northern pikeminnow $>$ $275 \mathrm{~mm}$ FL (11 inches total length). The Northern Pikeminnow Management Program (NPMP) was created in 1990, with the goal of implementing fisheries which achieve the recommended $10-20 \%$ annual exploitation on northern pikeminnow $>275 \mathrm{~mm}$ FL within the program area (Vigg and Burley 1989). In 2000, NPMP administrators reduced the minimum size for eligible (reward size) northern pikeminnow to $228 \mathrm{~mm}$ FL (9 inches total length) in response to recommendations contained in a review of NPMP justification, performance, and costeffectivenesss (Hankin and Richards 2000). Beginning in 1991, the Washington Department of Fish and Wildlife (WDFW) was contracted to conduct the NPSRF component of the NPMP (Burley et al. 1992). The NPSRF enlists recreational anglers to harvest reward sized ( $\geq 9$ " total length) northern pikeminnow from within program boundaries on the Columbia and Snake Rivers by using a monetary reward system. Since 1991, anglers participating in the NPSRF have harvested more than 3.3 million reward sized northern pikeminnow and spent nearly 689,000 angler days of effort to become the NPMP's most successful component for achieving the annual $10-20 \%$ exploitation rate on northern pikeminnow within the program boundaries (Klaybor et al. 1993; Friesen and Ward 1999).

The 2008 NPSRF maintained the tiered angler reward system developed in 1995 (Hisata et al. 1995) which paid anglers higher rewards per fish based on achieving designated harvest levels and a separate bonus reward for returning northern pikeminnow spaghetti tagged by the Oregon Department of Fish and Wildlife (ODFW) as part of the NPSRF's biological evaluation. Catch and harvest data were collected from returning anglers, and non-returning anglers in order to monitor the effects of the NPSRF on other Columbia basin fishes.

The objectives of the 2008 NPSRF were to (1) implement a public fishery that rewards recreational anglers for harvesting northern pikeminnow $\geq 228 \mathrm{~mm}$ (9 inches) total length, (2) collect, compile, and report data on angler participation, catch and harvest of northern pikeminnow and other fish species, and success rates of participating anglers during the season, (3) examine collected northern pikeminnow for the presence of external tags, fin-clips, and signs of tag loss, (4) collect biological data on northern pikeminnow and other fish species returned to registration stations, (5) scan northern pikeminnow for the presence of consumed salmonids containing Passive Integrated Transponder (PIT) tags, (6) survey non-returning fishery participants targeting northern pikeminnow in order to obtain catch and harvest data on fish species caught, and (7) examine and process all northern pikeminnow caught by U.S. Department of Agriculture (USDA) angling crews operating at The Dalles and John Day dams to recover spaghetti and/or PIT tags. 


\section{METHODS OF OPERATION}

\section{Fishery Operation}

\section{Boundaries and Season}

The 2008 NPSRF was conducted on the Columbia River from the mouth to the boat-restricted zone below Priest Rapids Dam, and on the Snake River from the mouth to the boat-restricted zone below Hells Canyon Dam (Figure 1). In addition, anglers were allowed to harvest (and submit for payment) northern pikeminnow caught in backwaters, sloughs, and up to 400 feet from the mouth of tributaries within this area.

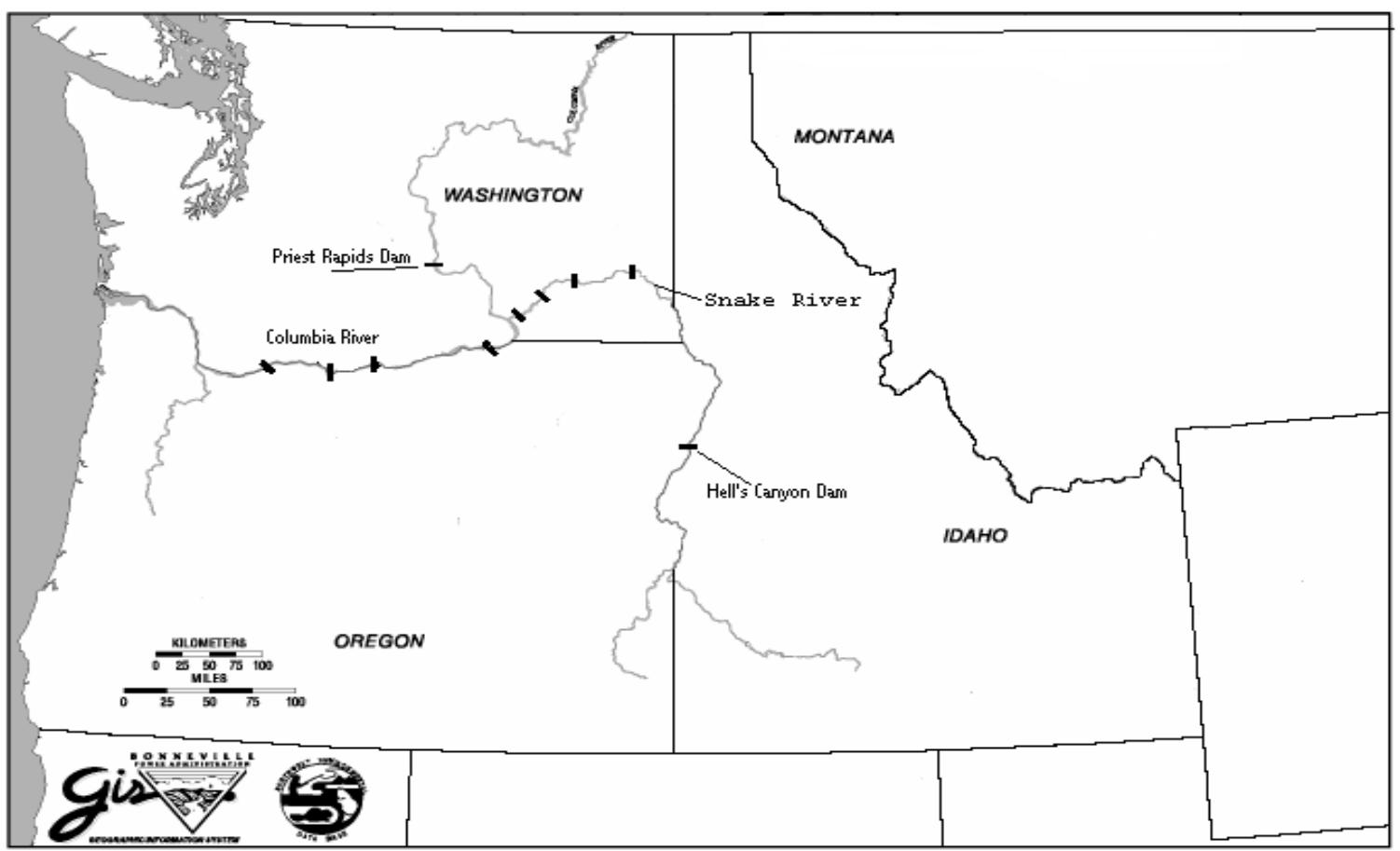

Figure 1. Northern Pikeminnow Sport-Reward Fishery Program Area

The NPSRF was fully implemented, with all stations operating from May 5 through September 28, 2008. In addition, thirteen stations conducted a fifteen day "post-season extension" beginning on October 1, 2008 in order to take advantage of favorable river conditions and provide anglers with an extended opportunity to harvest northern pikeminnow. 


\section{Registration Stations}

Seventeen registration stations (Figure 2) were located on the Columbia and Snake Rivers to provide anglers with access to the Sport-Reward Fishery. Additionally, a station at the Ridgefield Marina was operated during the extension on a trial basis in order to determine whether effort and harvest warranted consideration as a registration station during 2009.

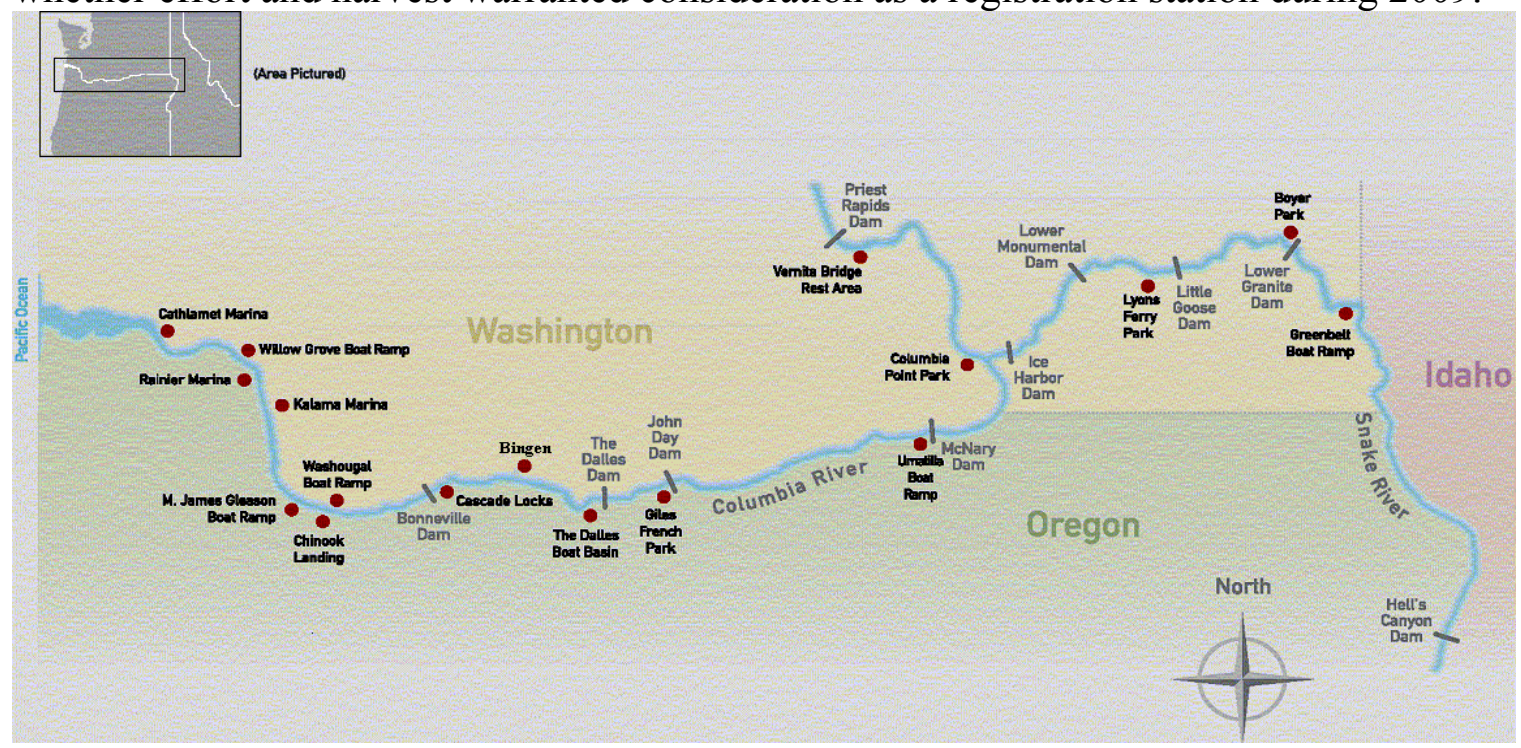

1. Cathlamet Marina (11am-3 pm)

2. Willow Grove Boat Ramp (4-7 pm)

3. Rainier Marina (3-7:00 pm)

4. Kalama Marina (10:30am-2:30 pm)

5. M. James Gleason Boat Ramp (11am-7 pm)

6. Chinook Landing (7-10 am)

7. Washougal Boat Ramp (11am-7 pm)

8. Cascade Locks Boat Ramp (4-7 pm)

9. Bingen Marina (11am-3:00 pm)
10.The Dalles Boat Basin (11am-7 pm)

11. Giles French (11am-7 pm)

12. Umatilla Marina (4-6 pm)

13. Columbia Point Park (2-6:30 pm)

14. Vernita Bridge (10am-2:30 pm)

15. Lyon's Ferry (10:30am-12:30 pm)

16. Boyer Park (10:30 am-2 pm)

17. Greenbelt (3:30-6:30 pm)

Figure 2. 2008 Northern Pikeminnow Sport Reward Fishery Registration Stations

WDFW technicians set up registration stations daily (seven days a week) at designated locations (normally public boat ramps or parks) which were available to anglers between two and eight hours per day during the season. Technicians registered anglers to participate in the NPSRF, collected angler creel information, issued pay vouchers to anglers returning with eligible northern pikeminnow, recorded biological data, scanned northern pikeminnow for the presence of PIT tags, and provided Sport-Reward Fishery information to the public. Self-registration boxes were located at each station so anglers could self register when WDFW technicians were not present.

\section{Reward System}

The 2008 NPSRF rewarded anglers for harvesting northern pikeminnow $\geq 228 \mathrm{~mm}$ TL $\quad$ (9 inches). The 2008 NPSRF maintained the tiered angler reward system developed in 1995 
(Hisata et al. 1995) that paid anglers a higher reward per fish once they had reached designated harvest levels over the course of the season. To receive payment, anglers returned their catch (daily) to the location where they had registered. WDFW technicians identified the angler's fish and issued a payment voucher for the total number of eligible northern pikeminnow. Anglers mailed payment vouchers to the Pacific States Marine Fisheries Commission (PSMFC) for redemption. Anglers returning with northern pikeminnow that were spaghetti-tagged by ODFW as part of the biological evaluation of the fishery (Vigg et al. 1990), were issued a separate tag payment voucher that was mailed to ODFW for tag verification before payment was made to the angler by PSMFC. During the 2008 season, the NPSRF retained the pay levels used in 2007 (Hone et al. 2007) which paid anglers $\$ 4$ each for their first 100 northern pikeminnow, $\$ 5$ each for numbers $101-400$, and $\$ 8$ each for all fish over 400 . Anglers were paid $\$ 500$ for each northern pikeminnow which retained a valid spaghetti tag used by ODFW for the biological evaluation of the NPMP.

\section{Angler Sampling}

Angler data and creel data for the NPSRF were compiled from angler registration forms. One registration form represented one angler day. Angler data consisted of name, date, fishing license number, phone number, and city, state, zip code of participating angler. Creel data recorded by WDFW technicians included fishing location (Figure 3), and primary species targeted (Appendix B). Anglers were asked if they specifically fished for northern pikeminnow at any time during their fishing trip. A "No" response ended the exit interview. A "Yes" response prompted technicians to ask the angler (and record data), how many of each species of fish were caught, harvested or released while targeting northern pikeminnow. A fish was considered "caught" when the angler touched

the fish, whether it was released or harvested. Fish returned to the water alive were defined as "released". Fish that were retained by the angler or not returned to the water alive were considered "harvested". 

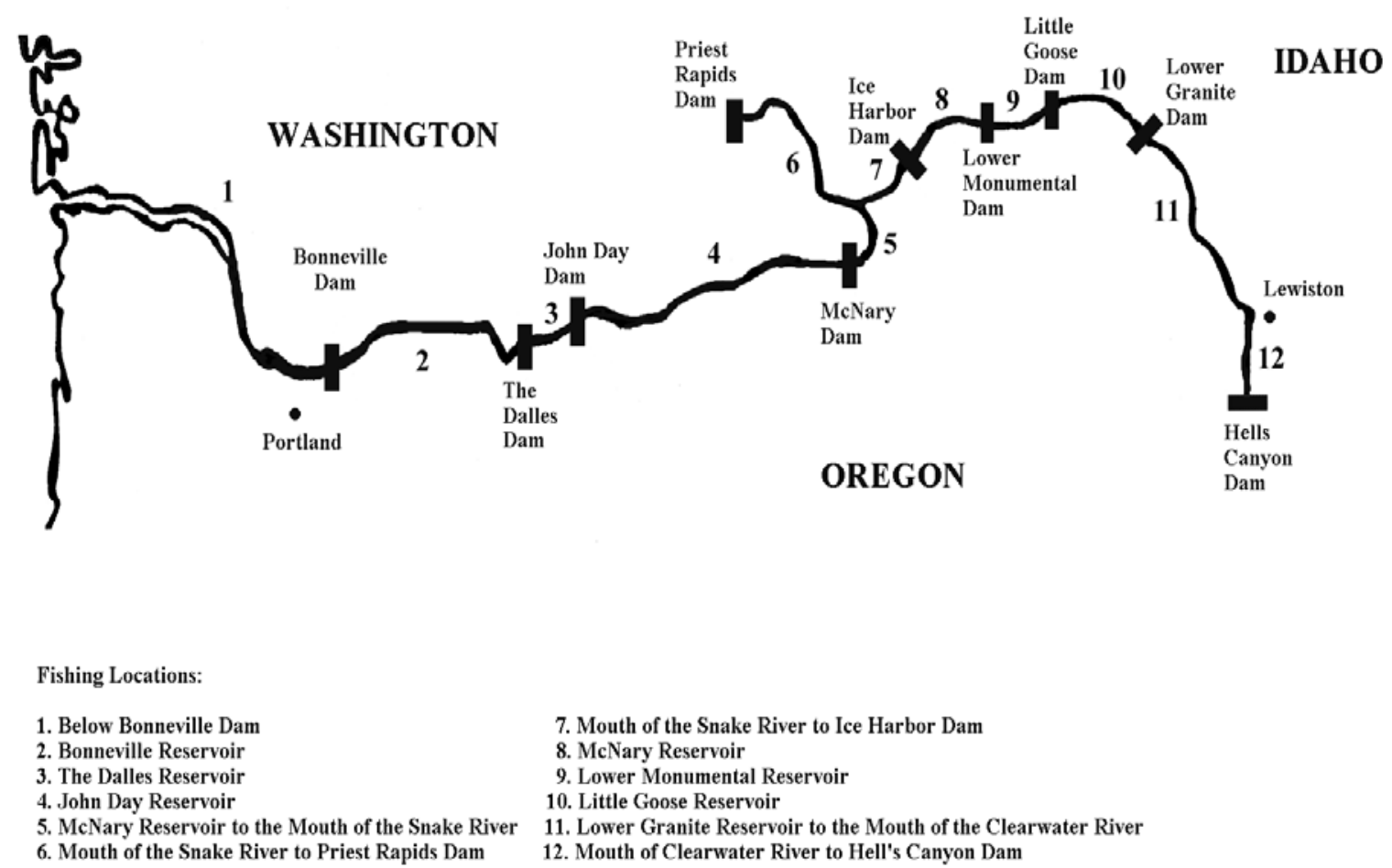

7. Mouth of the Snake River to Ice Harbor Dam 8. McNary Reservoir

9. Lower Monumental Reservoir

10. Little Goose Reservoir

11. Lower Granite Reservoir to the Mouth of the Clearwater River

12. Mouth of Clearwater River to Hell's Canyon Dam

Figure 3. Fishing location codes used for the 2008 Northern Pikeminnow Sport-Reward Fishery

\section{Returning Anglers}

Technicians interviewed all returning anglers at each registration station to obtain any missing angler data, and to record creel data from each participant's angling day. Creel data from caught and released fishes were recorded from angler recollection. Creel data from all harvested fish species were recorded from visual observation.

\section{Non-Returning Anglers}

Non-returning angler data were compiled from the pool of anglers who had registered for the NPSRF and targeted northern pikeminnow, but did not return to a registration station to participate in an exit interview. WDFW attempted to survey $20 \%$ of the NPSRF's non-returning anglers using a telephone survey in order to obtain creel data from that segment of the NPSRF's participants. To obtain the $20 \%$ sample, non-returning anglers were randomly selected from each registration station for each week. A technician called anglers from each random sample until the $20 \%$ sample was attained. Non-returning anglers were surveyed with the same exit interview questions used for returning anglers. Anglers were asked: "did you specifically fish for northern pikeminnow at any time during your fishing trip?" With a "Yes" response, anglers were asked to report the number and species of adult and/or juvenile salmonids and the number of reward size northern pikeminnow that were caught and harvested/released while they targeted northern pikeminnow. Angler catch and harvest data were not collected from non-returning 
anglers who did not target northern pikeminnow on their fishing trip. In addition, non-returning angler catch and harvest data for non-salmonid species were not collected in 2008 as it was last obtained in 2005 and trends for these species have remained consistent over the NPMP's 18 year history (Winther et al. 1996). These data will be again collected in 2010 to identify any variance from non-returning angler trends observed to date within the Sport-Reward Fishery.

\section{Northern Pikeminnow Handling Procedures}

\section{Biological Sampling}

Technicians examined all fishes returned to registration stations and recorded species as well as number of fish per species. Technicians checked all northern pikeminnow for the presence of external tags (spaghetti or dart), fin-clip marks, and signs of tag loss. Fork lengths (FL) and sex of northern pikeminnow as well as any other harvested fish species were recorded whenever possible. Complete biological data were collected from all tag-loss and spaghetti tagged northern pikeminnow including FL, sex (determined by evisceration), scale, and opercle samples. Spaghetti tagged and tag-loss northern pikeminnow carcasses were then labeled and frozen for data verification and/or tag recovery at a later date. Data from spaghetti tags were recorded on a tag envelope as well as on WDFW data forms. The spaghetti tag was then placed in the tag envelope, stapled to the tag payment voucher and given to the angler to submit to ODFW for verification.

\section{PIT Tag Detection}

All northern pikeminnow collected during the 2008 NPSRF were also scanned for passive integrated transponder (PIT) tags. Northern pikeminnow harvested by anglers participating in the NPSRF have been found to ingest juvenile salmonids which have been PIT tagged by other studies within the basin (Glaser et al. 2000). In addition, PIT tags have also been used by ODFW as a secondary mark in all northern pikeminnow fitted with spaghetti tags (beginning in 2003) as part of the NPMP's biological evaluation activities. The use of PIT tags rather than fin clips as a secondary mark in northern pikeminnow has improved the NPSRF's estimate of tag loss, and resulted in a more accurate estimate of exploitation for the NPSRF. WDFW technicians scanned $100 \%$ of all northern pikeminnow returned to registration stations for PIT tags using two types of PIT tag "readers". Northern Pikeminnow were scanned using primarily Destron Fearing portable transceiver systems (model \#FS2001F) to record information from PIT tag detections for submission to the Columbia Basin PIT tag information System (PTAGIS). The NPSRF also used Allflex ISO Compatible RF/ID Portable Readers (model \#RS601) to scan northern pikeminnow and assist in recovery of initial PIT tag data when the Dextrons were not available. Scanning began on the first day of the NPSRF season and continued at all stations throughout the rest of the year. Technicians individually scanned all reward sized northern pikeminnow for PIT tag presence and complete biological data were recorded from pikeminnow with positive readings. All PIT tagged northern pikeminnow were labeled and preserved for later dissection and tag recovery. All data were verified after recovery of PIT tags and all PIT 
tag recovery data were provided to ODFW and the Pit Tag Information System (PTAGIS) on a regular basis.

\section{Northern Pikeminnow Processing}

During biological sampling, all northern pikeminnow were eviscerated (to determine sex), or caudal clipped as an anti-fraud measure to eliminate the possibility of previously processed northern pikeminnow being resubmitted for payment. As in recent years, most northern pikeminnow harvested in 2008 were caudal clipped rather than eviscerated in order to facilitate more accurate recovery of PIT tags. Sampled northern pikeminnow were iced and transported to cold storage facilities from which they were ultimately delivered to rendering facilities for final disposal.

\section{RESULTS AND DISCUSSION}

\section{Northern Pikeminnow Harvest}

The NPSRF harvested a total of 159,806 reward size northern pikeminnow ( $\geq 228 \mathrm{~mm}$ TL) during the 2008 season, operating for a 21 week regular season, plus a fifteen day extension (at limited stations). This was 2 weeks longer than the 2007 NPSRF, which began one week later and ended a week earlier (Hone et al. 2007). Even with the longer season, 2008 harvest declined by 32,712 fish from 2007, and fell well below the mean 1991-2007 harvest of 179,053 fish (Figure 4). Despite below average harvest, the 2008 NPSRF did however record the highest exploitation rate in NPMP history at $19.5 \%$ (ODFW, personal communication). Also, in addition to harvesting 159,806 reward size northern pikeminnow, the 2008 NPSRF also harvested 3,507 northern pikeminnow $<228 \mathrm{~mm}$ TL.

\section{NPSRF ANNUAL HARVEST BY YEAR}

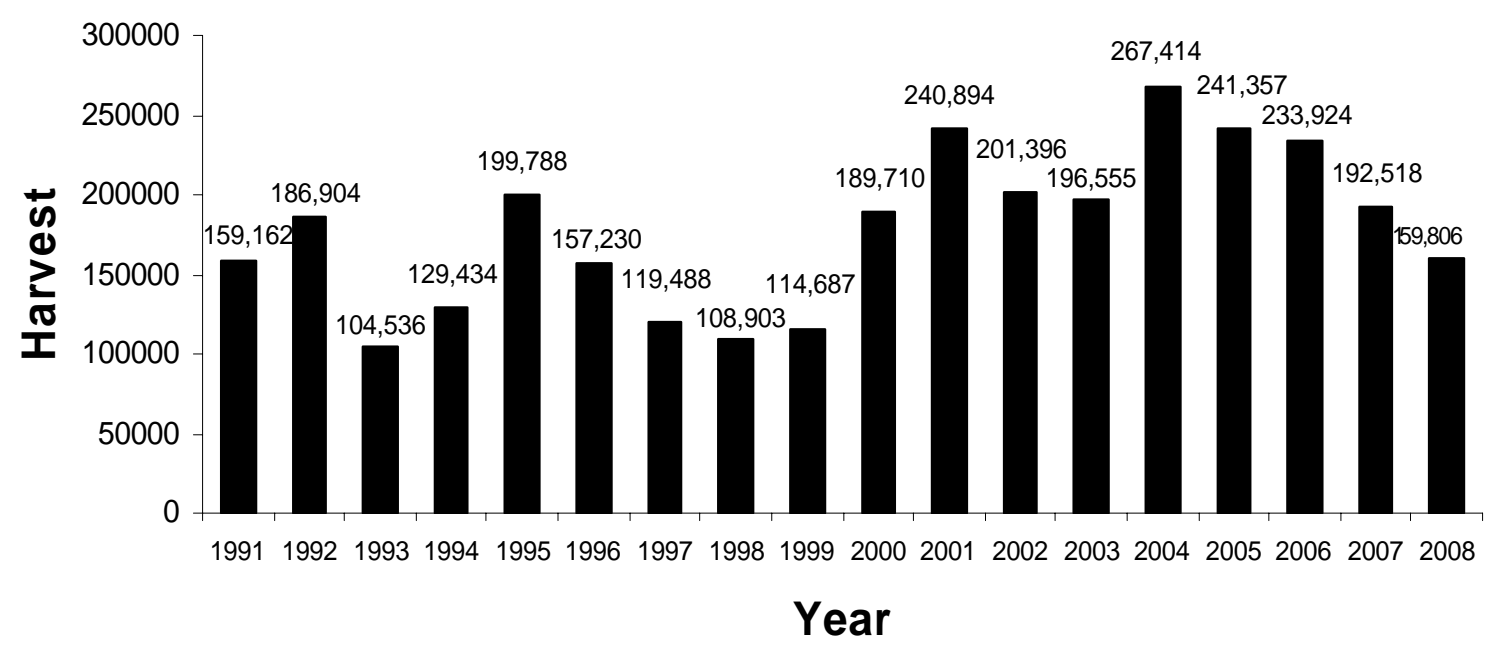

Figure 4. Annual Harvest Totals for the Northern Pikeminnow Sport Reward Fishery 


\section{Harvest by Week}

Mean weekly harvest for the 2008 NPSRF was 7,042 fish during the regular season, 3,976 during the extension, and 6,659 overall (Figure 5). Weekly harvest totals for the first seven weeks of the 2008 NPSRF were considerably lower than totals for that period in 2007, but were thereafter similar for the remainder of the season (Figure 6). Weekly harvest for the 2008 NPSRF was also lower than mean 1991-2007 weekly harvest levels for the first 13 weeks of the season (Figure 7), then rising above historical 1991-2007 weekly harvest levels and remaining there for the rest of the regular season (week 39). Peak harvest was 11,200 fish and occurred during the ninth week of the season (week 27), June 30-July 6. This peak was lower and one week later than the NPSRF's historical 1991-2007 peak in week 26 (Fox et al. 1999). Although high weekly harvest levels prior to the spawn are typically necessary for the NPSRF to achieve above average harvest and exploitation rates, the results of the 2008 season demonstrate that this is not always the case.

\section{Harvest by Week}

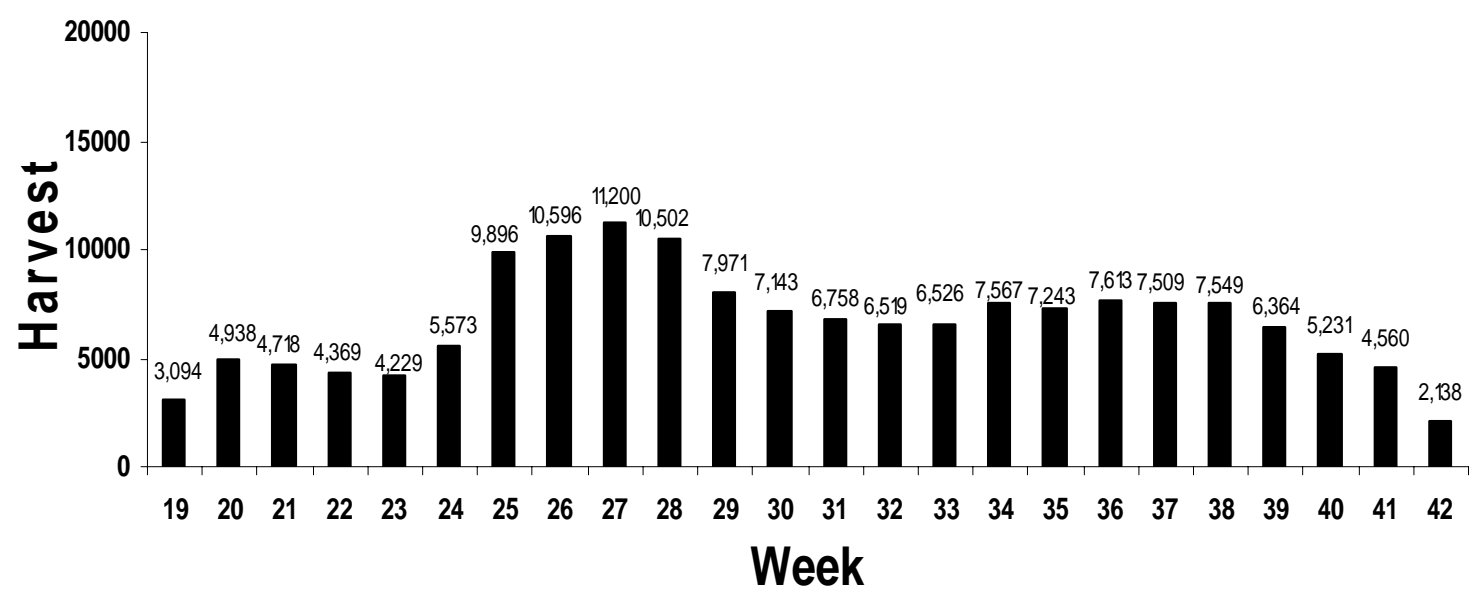

Figure 5. 2008 Weekly Northern Pikeminnow Sport-Reward Fishery Harvest.

2008 Harvest vs 2007 Harvest

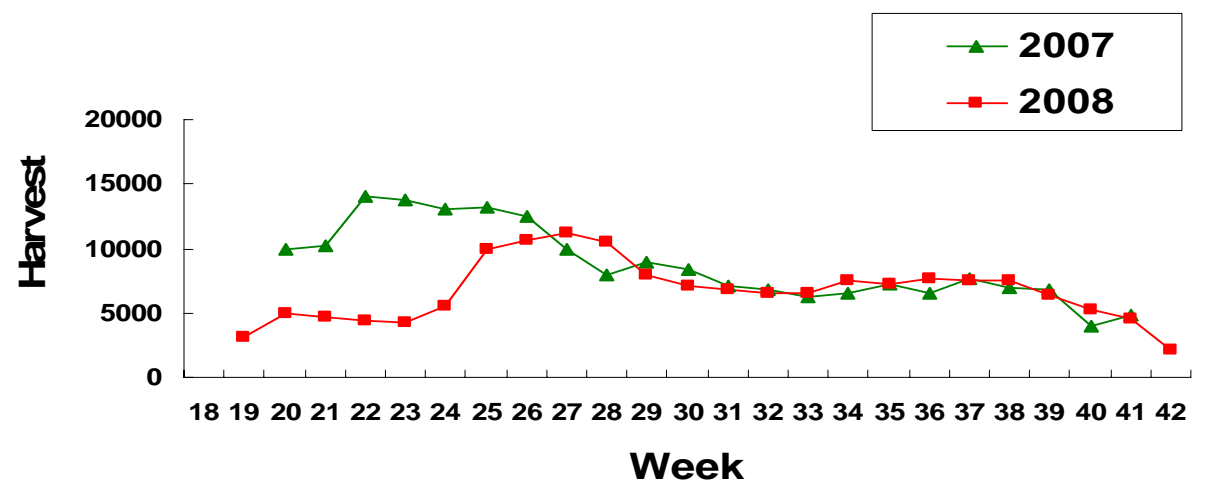

Figure 6. 2008 Weekly NPSRF Harvest vs. 2007 Weekly Harvest. 


\section{Harvest vs. Mean 1991-2007 Harvest}

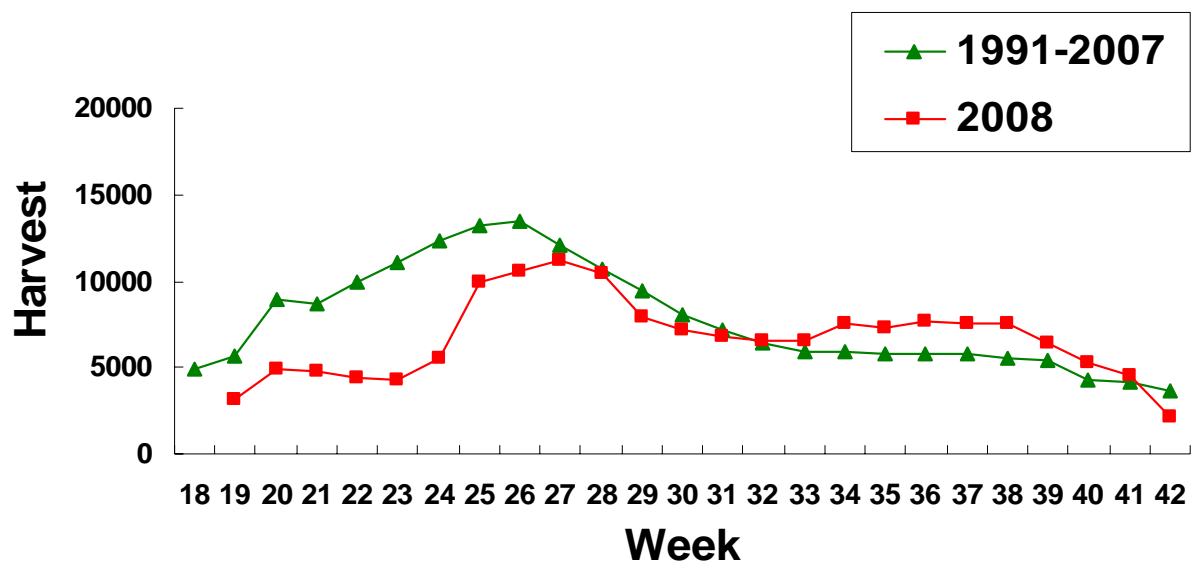

Figure 7. Comparison of 2008 NPSRF Weekly Harvest to 1991-2007 Mean Weekly Harvest.

\section{Harvest by Fishing Location}

The mean harvest by fishing location was 16,043 northern pikeminnow and ranged from 81,780 reward size northern pikeminnow in fishing location 01 (below Bonneville Dam) to 88 northern pikeminnow from fishing location 11 (Lower Granite Dam to the mouth of the Clearwater River) (Figure 8). Harvest from Fishing Location 01 (the Columbia river below Bonneville Dam) accounted for $42 \%$ of total NPSRF harvest and was once again the highest producing area as it has been for each year since 1991. Fishing location 10 (Little Goose Reservoir) was the second best area (in terms of total harvest) accounting for $23 \%$ of total 2008 NPSRF harvest. Fishing location 10 surpassed fishing location 02 for the first time since 2002 as the NPSRF's second best area for total northern pikeminnow harvest (Winther et al. 2006). The five mile stretch of river immediately below Lower Granite Dam in fishing location 10 has been responsible for a significant amount of total NPSRF harvest in past years, but not since 2002 (prior to reopening Boyer Park in 2004) has the area had both the top producing station and the second best fishing location. Bonneville Pool (Fishing location 02) continued to show a decline in harvest from the high levels first documented during the 2004 NPSRF (Hone et al. 2004).

\section{HARVEST BY FISH LOCATION}

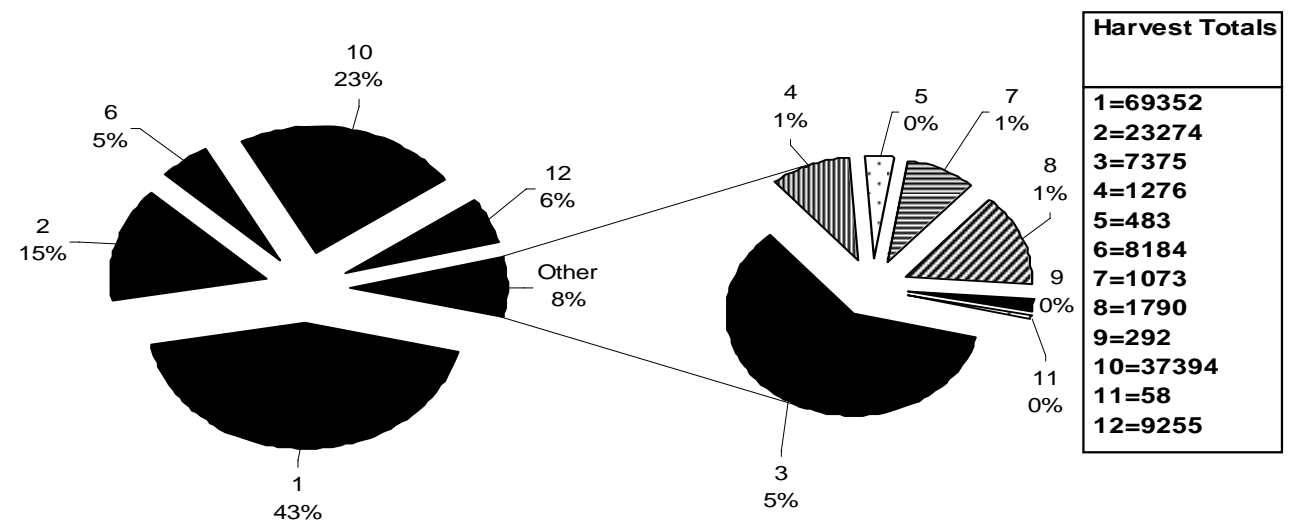

Figure 8. 2008 Northern Pikeminnow Sport-Reward Fishery Harvest by Fishing Location.* 
*Fishing Location Codes for Columbia River; 1 = Below Bonneville Dam, 2 = Bonneville Reservoir, 3 = The Dalles Reservoir, $4=$ John Day Reservoir, $5=$ McNary Dam to the mouth of the Snake River, $6=$ Mouth of the Snake River to Priest Rapids Dam. Fishing Location Codes for the Snake River; $7=$ Mouth of the Snake River to Ice Harbor Dam, $8=$ Ice Harbor Reservoir, 9 = Lower Monumental Reservoir, $10=$ Little Goose Reservoir, $11=$ Lower Granite Dam to the mouth of the Clearwater River, 12 = Mouth of the Clearwater River to Hell's Canyon Dam.

\section{Harvest by Registration Station}

Harvest was down from 2007 levels at 12 of the 17 registration stations operated during the 2008 NPSRF. The Boyer Park registration station was one of five stations with improved harvest in 2008 and was the NPSRF's top producing station for the second consecutive season. Boyer Park anglers harvested 36,368 northern pikeminnow (up from 32,717 in 2007), equaling $22.8 \%$ of the total 2008 NPSRF harvest (Figure 9). The average harvest per registration station was 9,400 reward size northern pikeminnow, down from 11,325 per station in 2007. The registration station with the smallest harvest was Umatilla where anglers harvested 1,749 northern pikeminnow. It should be noted however, that the three lowest producing stations were only open during very limited hours (2-3 hrs/day). The Columbia Point registration station showed the largest percent increase in harvest (up 30.5\%) improving from 3,261 northern pikeminnow in 2007 to 4,259 in 2008. The Giles French station showed the largest decline, dropping from 17,504 fish in 2007 to 7,644 in 2008 (a 56.5\% decrease).

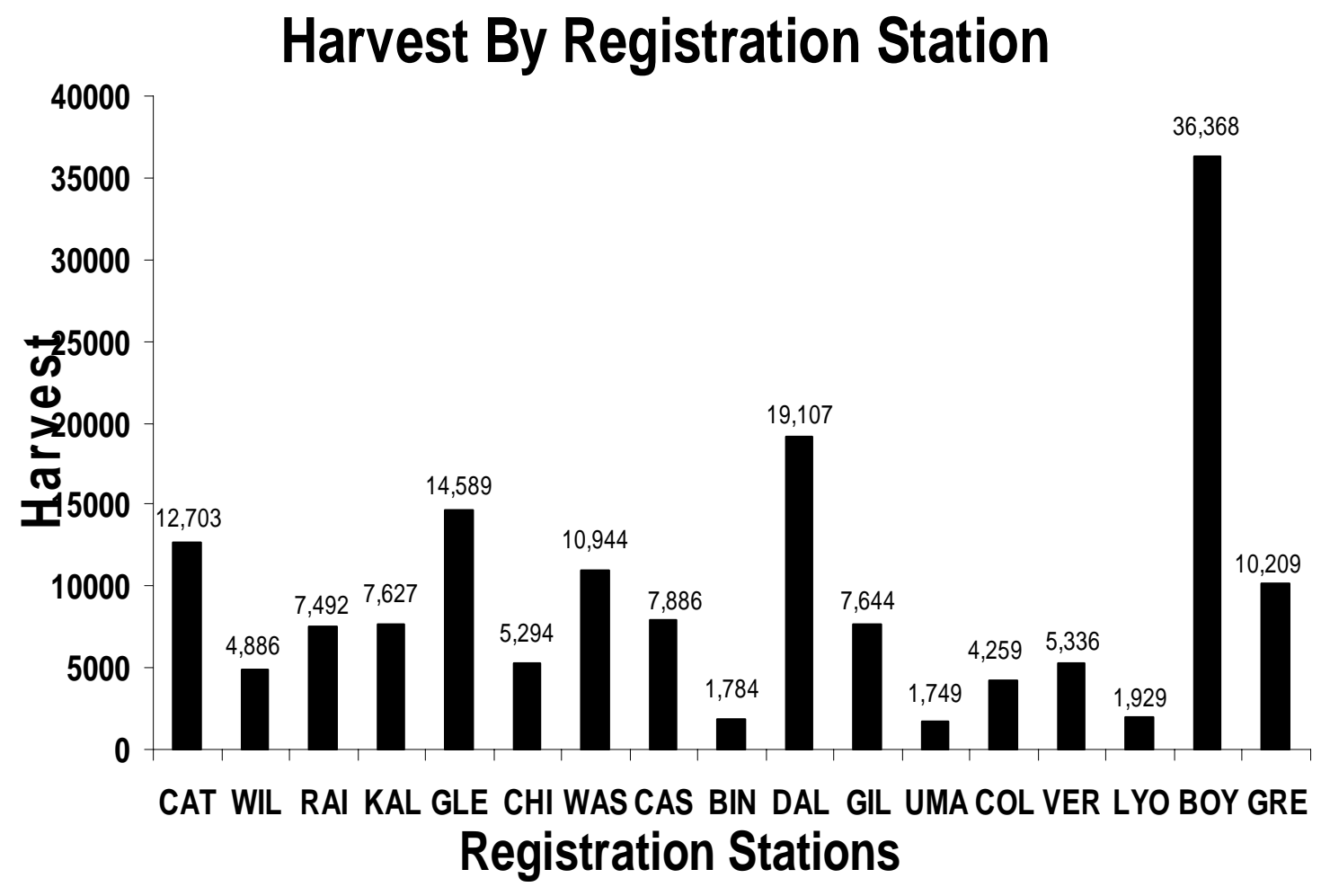

Figure 9. 2008 Northern Pikeminnow Sport-Reward Fishery Harvest by Registration Station.

CAT-Cathlamet, WIL-Willow Grove, RAI-Rainier, KAL-Kalama, GLE-Gleason, CHI-Chinook, WAS-Washougal, CAS-Cascade Locks, BIN-Bingen Marina, DAL-TheDalles, GIL-Giles French, UMA-Umatilla Marina, COL-Columbia Point, VER-Vernita, LYO-Lyon's Ferry, GRE-Greenbelt, BOY-Boyer Park. 


\section{Harvest by Species/ Incidental Catch}

\section{Returning anglers}

In addition to northern pikeminnow, returning anglers participating in the 2008 NPSRF reported that they incidentally caught the salmonids listed in Table 1. Incidental salmonid catch by returning NPSRF anglers consisted mostly of juvenile chinook and jack chinook. Anglers reported that all juvenile salmonids caught during the 2008 NPSRF were released. Technicians recorded any juvenile steelhead caught by NPSRF anglers (except those specifically reported as missing the adipose fin), as "wild". Harvested adult salmonids (hatchery fin-clipped chinook and steelhead with missing adipose fins) were caught incidentally during the 2008 NPSRF, but were only retained during legal salmonid fisheries. Instances where NPSRF anglers reported harvesting "trout" from the Snake River during a legal fishery are typically residualized hatchery steelhead smolts which are caught and kept by anglers, and misidentified as trout. Any NPSRF angler who reports illegally harvesting salmonids during the exit interview (whether juvenile or adult salmonids), are immediately reported to the appropriate enforcement entity by WDFW technicians.

Table 1. Catch and Harvest of salmonids by Returning Anglers Targeting Northern Pikeminnow in 2008.

\section{Salmon}

\begin{tabular}{lccc}
\hline Species & Caught & Harvest & Harvest Percent \\
\hline Chinook (Adult) & 48 & 7 & $14.58 \%$ \\
Chinook (Jack) & 64 & 15 & $23.44 \%$ \\
Chinook (Juvenile) & 69 & 0 & $0 \%$ \\
Coho (Juvenile) & 13 & 0 & $0 \%$ \\
Cutthroat (unknown) & 11 & 4 & $36.36 \%$ \\
Sockeye & 6 & 2 & $33.33 \%$ \\
Steelhead Adult (Hatchery) & 28 & 8 & $28.57 \%$ \\
Steelhead Adult (Wild) & 31 & 0 & $0 \%$ \\
Steelhead Juvenile (Hatchery) & 41 & 0 & $0 \%$ \\
Steelhead Juvenile (Wild) & 21 & 0 & $0 \%$ \\
Trout (Unknown) & 325 & 18 & $5.54 \%$
\end{tabular}

Other fish species incidentally caught by returning NPSRF anglers targeting northern pikeminnow were most often peamouth, smallmouth bass, Yellow Perch, Walleye, and channel catfish (Table 2).

Table 2. Catch and Harvest of non-salmonids by Returning Anglers Targeting Northern Pikeminnow in 2008.

\section{Non-Salmonid}

\begin{tabular}{lrrc}
\hline Species & Caught & Harvest & Harvest Percent \\
\hline Northern Pikeminnow >228mm & 159,835 & 159,806 & $99.98 \%$ \\
Northern Pikeminnow <228mm & 53,120 & 3,507 & $6.60 \%$ \\
Peamouth & 44,482 & 9,902 & $22.08 \%$ \\
Smallmouth Bass & 17,302 & 2,077 & $12.00 \%$ \\
Channel Catfish & 6,215 & 1,186 & $19.08 \%$ \\
Sculpin (unknown) & 6,202 & 2,119 & $34.17 \%$ \\
Sucker (unknown) & 3,982 & 365 & $9.17 \%$
\end{tabular}




$\begin{array}{lrrc}\text { White Sturgeon } & 3,975 & 81 & 2.04 \% \\ \text { Yellow Perch } & 1,636 & 404 & 24.69 \% \\ \text { Walleye } & 738 & 443 & 60.03 \% \\ \text { American Shad } & 122 & 55 & 45.08 \% \\ \text { Starry Flounder } & 966 & 140 & 14.49 \% \\ \text { Catfish (unknown) } & 951 & 262 & 27.55 \% \\ \text { Carp } & 665 & 50 & 7.52 \% \\ \text { Chiselmouth } & 484 & 70 & 14.46 \% \\ \text { Sandroller } & 478 & 1 & .21 \% \\ \text { Bullhead (unknown) } & 382 & 43 & 11.26 \% \\ \text { Bluegill } & 84 & 19 & 22.62 \% \\ \text { Redside Shiner } & 44 & 2 & 4.55 \% \\ \text { Largemouth Bass } & 28 & 0 & 0 \% \\ \text { Pumpkinseed } & 13 & 2 & 15.38 \% \\ \text { Crappie (unknown) } & 10 & 0 & 0 \% \\ \text { Whitefish } & 6 & 1 & 16.67 \%\end{array}$

Non-returning Anglers Catch and Harvest Estimates

We randomly surveyed 1,776 non-returning anglers (21.92\% of all non-returning anglers) to record their catch and/or harvest of reward sized northern pikeminnow or any salmonid species. Catch and harvest data for other fish species caught by non-returning anglers were not collected in 2008 since harvest levels of those species by NPSRF anglers has been historically very low (Bruce et al. 2005), and was last obtained during the 2005 NPSRF. We anticipate once again collecting full catch and harvest data for all species from surveyed non-returning anglers in 2010 to determine whether this trend has changed per NPMP protocol (Fox et al. 1999). Surveyed non-returning anglers targeting northern pikeminnow reported that they caught and/or harvested the salmonid species listed in column 1 of Table 3 during the 2008 NPSRF. A simple estimator was applied to the

catch and harvest totals obtained from the surveyed anglers to obtain Total Catch, and Total Harvest estimates for all non-returning anglers participating in the 2008 NPSRF. Estimated totals are listed in columns 4 and 5 of Table 3.

Table 3. 2008 NPSRF Catch and Harvest for surveyed Non-returning Anglers and Estimated non-return totals.

\begin{tabular}{|c|c|c|c|c|c|}
\hline Species & Caught & $\underline{\text { Harvested }}$ & \%Harvested & $\begin{array}{l}\text { Estimated } \\
\text { Total Catch }\end{array}$ & $\begin{array}{l}\text { Estimated } \\
\text { Total } \\
\text { Harvest }\end{array}$ \\
\hline Northern Pikeminnow > $228 \mathrm{~mm}$ & 72 & 66 & $91.67 \%$ & 360 & $\frac{130}{330}$ \\
\hline Steelhead (juvenile - Adipose absent) & 1 & 0 & 0 & 5 & 0 \\
\hline Steelhead (juvenile - Adipose present) & 12 & 0 & 0 & 60 & 0 \\
\hline Steelhead (adult - Adipose present) & 3 & 0 & 0 & 15 & 0 \\
\hline Chinook (juvenile) & 4 & 0 & 0 & 20 & 0 \\
\hline Chinook (adult) & 1 & 0 & 0 & 5 & 0 \\
\hline Chinook (jack) & 9 & 1 & $11.11 \%$ & 45 & 5 \\
\hline
\end{tabular}

$\mathrm{N}=\mathbf{8 , 1 0 1} \quad \mathrm{n}=1,776$ 


\section{Fork Length Data}

The length frequency distribution of harvested northern pikeminnow ( $\geq 200 \mathrm{~mm}$ ) from the 2008 NPSRF is presented in Figure 10. Fork length data for a total of 60,774 northern pikeminnow (38\% of total) were taken during the 2008 NPSRF. $96 \%$ of the fish measured had a fork length $>$ $209 \mathrm{~mm}$, which we estimate to be the minimum size at which northern pikeminnow are eligible for reward payment (Glaser et al. 2000). The mean fork length for all measured northern pikeminnow ( $\geq 200 \mathrm{~mm}$ ) in 2008 was $295.1 \mathrm{~mm}$ ( $\mathrm{SD}=77.9 \mathrm{~mm}$ ), up from 290.4 in 2007 .

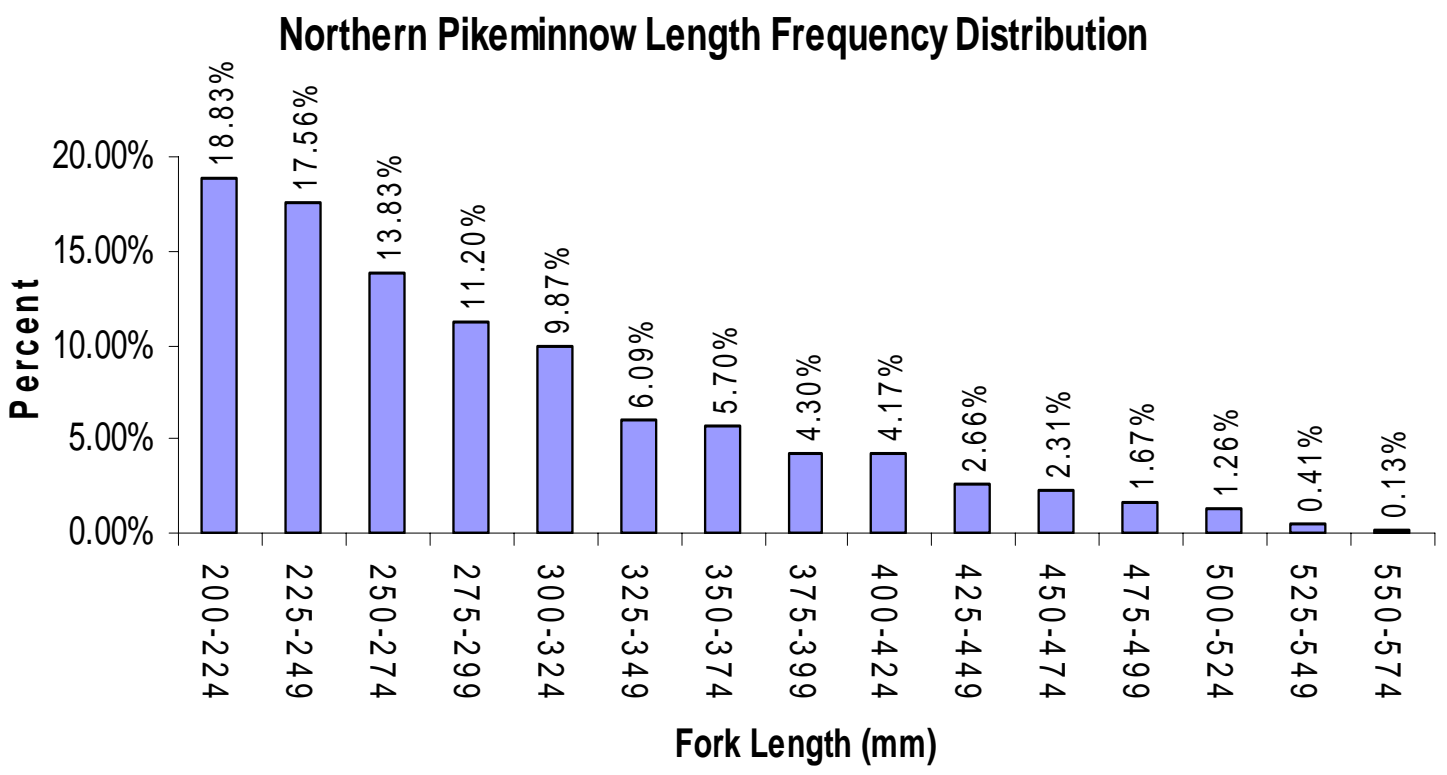

Figure 10. Length frequency distribution of northern pikeminnow $\geq 200 \mathrm{~mm}$ FL from 2008 NPSRF.

\section{Angler Effort}

The 2008 NPSRF recorded total effort of 26,141 angler days spent during the season, a drop of 783 angler days from the effort total of the previous year (Hone et al. 2007) (Figure 11). Peak effort for the 2008 NPSRF once again occurred near peak harvest in late June; however the addition of the Pikeminnow Angler Random Drawing incentive caused a second peak which nearly equaled it. This incentive, which was designed to increase angler participation, caused effort to surge to within 42 angler days of the season peak. When total effort is divided into returning and non-returning angler days, 18,040 angler days (69\%) were recorded by returning anglers, and 8,101 were non-returns. The percentage of returning anglers showed a slight increase from 2007 (68.3\%), and is consistent with the upward trend that the NPSRF has seen in recent years. In addition, $59 \%$ of total effort, and $86 \%$ of returning angler effort $(15,457$ angler 
days), was attributed to successful anglers who harvested at least 1 northern pikeminnow in 2008.

\section{NPSRF ANNUAL EFFORT BY YEAR}

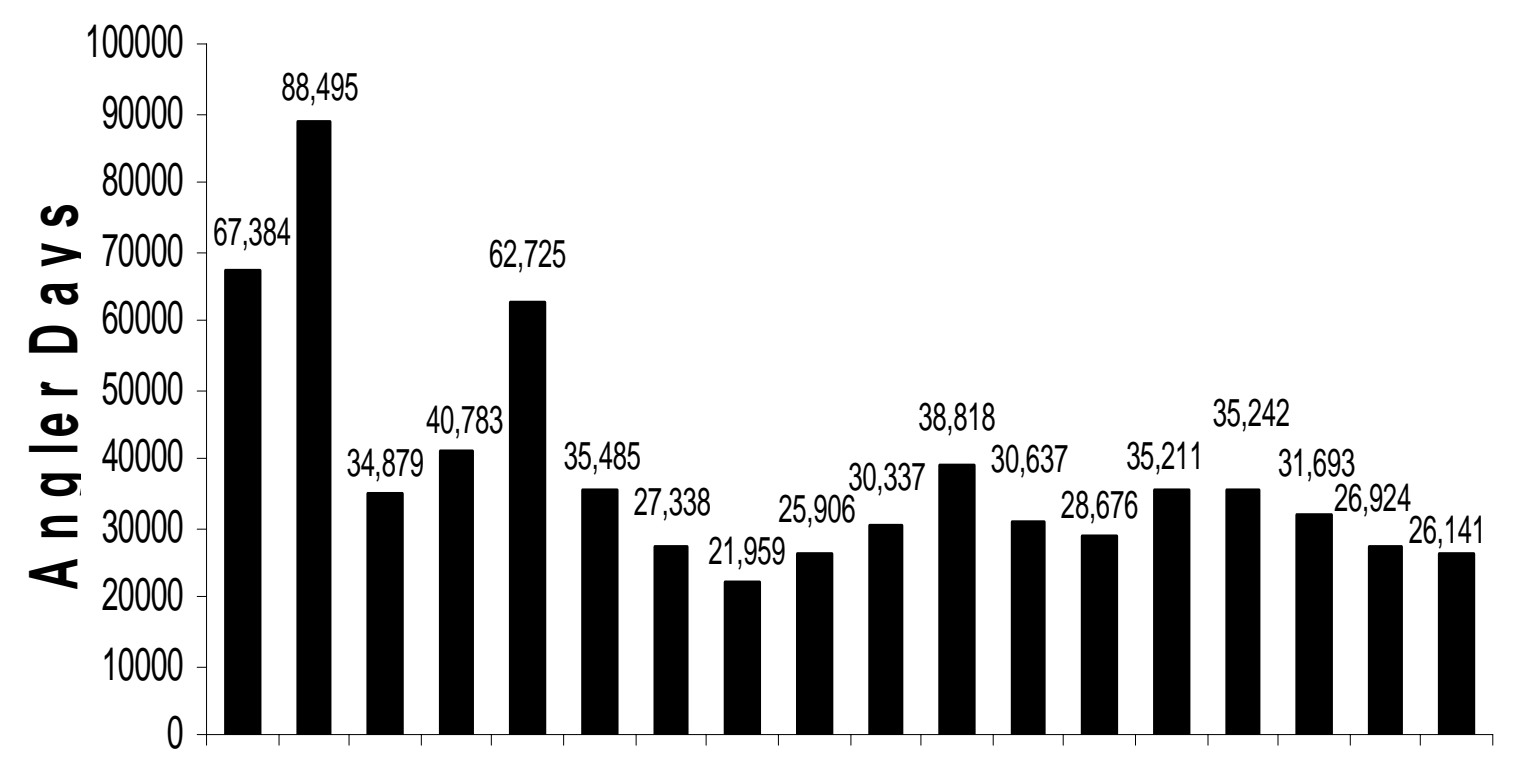

199119921993199419951996199719981999200020012002200320042005200620072008

\section{Year}

Figure 11. Annual Northern Pikeminnow Sport-Reward Fishery Effort.

\section{Effort by Week}

Mean weekly effort for the 2008 NPSRF was 1,184 angler days during the regular season, declining to 423 angler days during the extension, and 1,089 overall. Effort peaked during week 25 and then spiked upward again in week 35 as a result of starting the special Pikeminnow Angler Random Drawing incentive (Figure 12). Peak weekly effort typically occurs near peak weekly harvest, although this season it peaked 2 weeks prior to the harvest peak. Overall mean weekly effort declined from 1,224 in 2007 to 1,089 in 2008 (Hone et al. 2007). The weekly effort totals for the 2008 NPSRF generally followed the pattern of previous seasons until week 35, when the angler drawing incentive began (Figure 13). At that point, effort jumped above historical levels and remained there until the last week of the extension. Other than the final five weeks of the 2008 season (plus the extension), effort fell below historical 1991-2006 effort levels, continuing a trend that the NPSRF has experienced since the first years of the program.

Mean annual effort by fishing location for the 2008 NPSRF (returning anglers only) was 1,503 angler days compared to 1,528 angler days in 2007. Effort totals ranged from 8,220 angler days recorded below Bonneville Dam (fishing location 01) to only 30 angler days spent in fishing 
location 11 on the Snake River (Lower Granite Dam to the mouth of the Clearwater River) (Figure 14). While effort declined by 356 angler days in fishing

\section{Effort by Week}

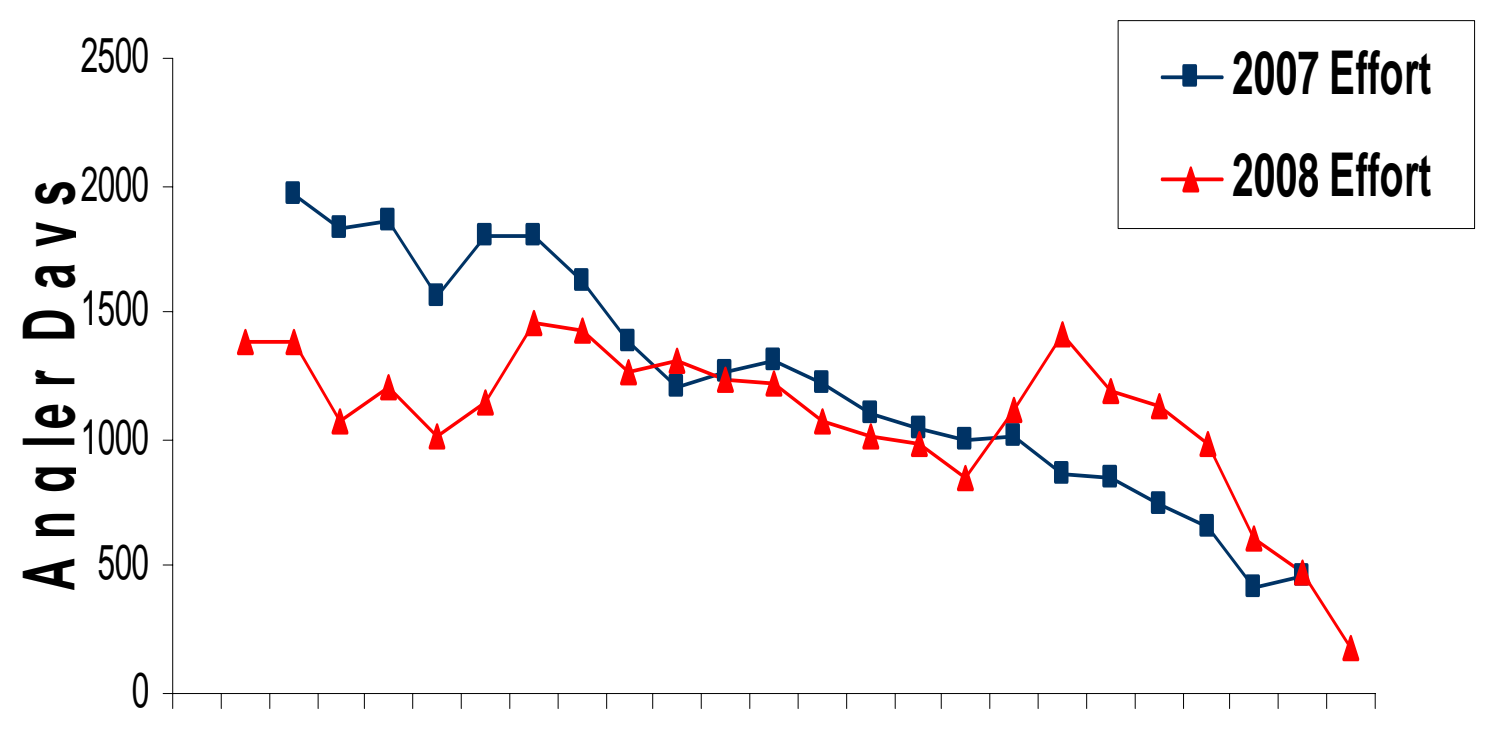

18192021222324252627282930313233343536373839404142

\section{Week Number}

Figure 12. 2008 Weekly Northern Pikeminnow Sport-Reward Fishery Effort vs 2007 Weekly Effort.

\section{Effort vs. Mean 1991-2007 Effort}

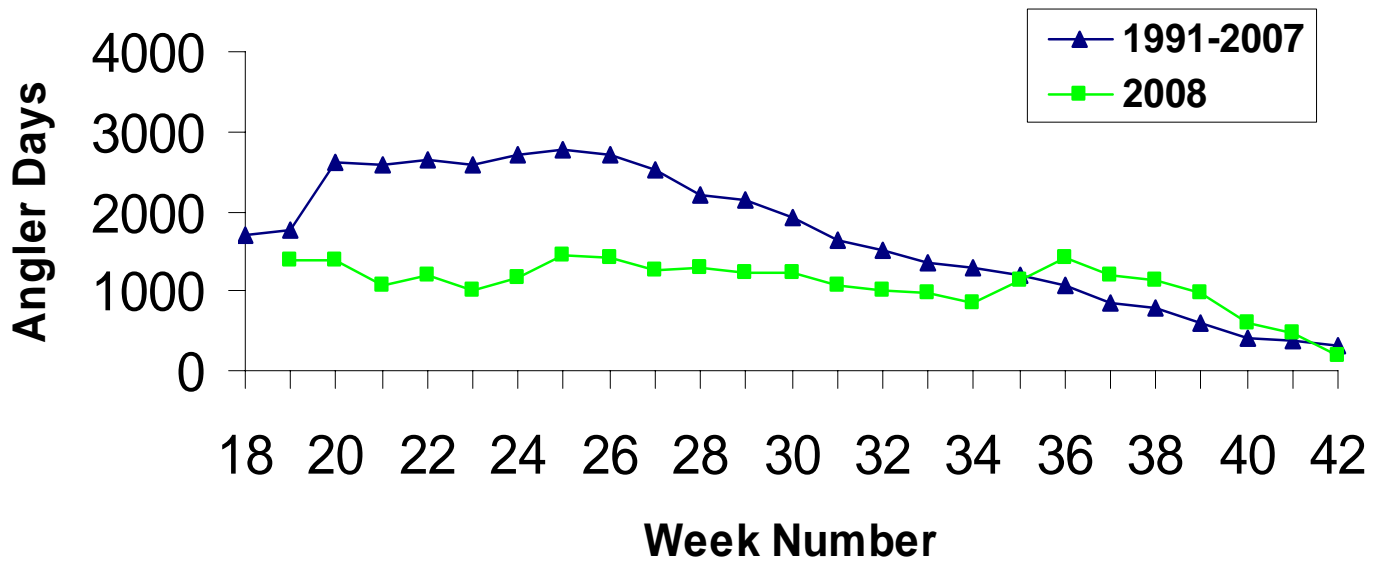

Figure 13. 2008 NPSRF Weekly Effort vs. Mean 1991-2007 Effort. 


\section{Effort by Fishing Location}

location 01 , it was nearly made up by an increase in effort of 328 angler days in fishing location 10. Besides fishing locations 01 and 10, effort actually improved from 2007 to 2008 at all but three fishing locations. Fishing location 03 (The Dalles Dam to John Day Dam), had the next largest decrease in effort, losing 336 angler days from 2007.

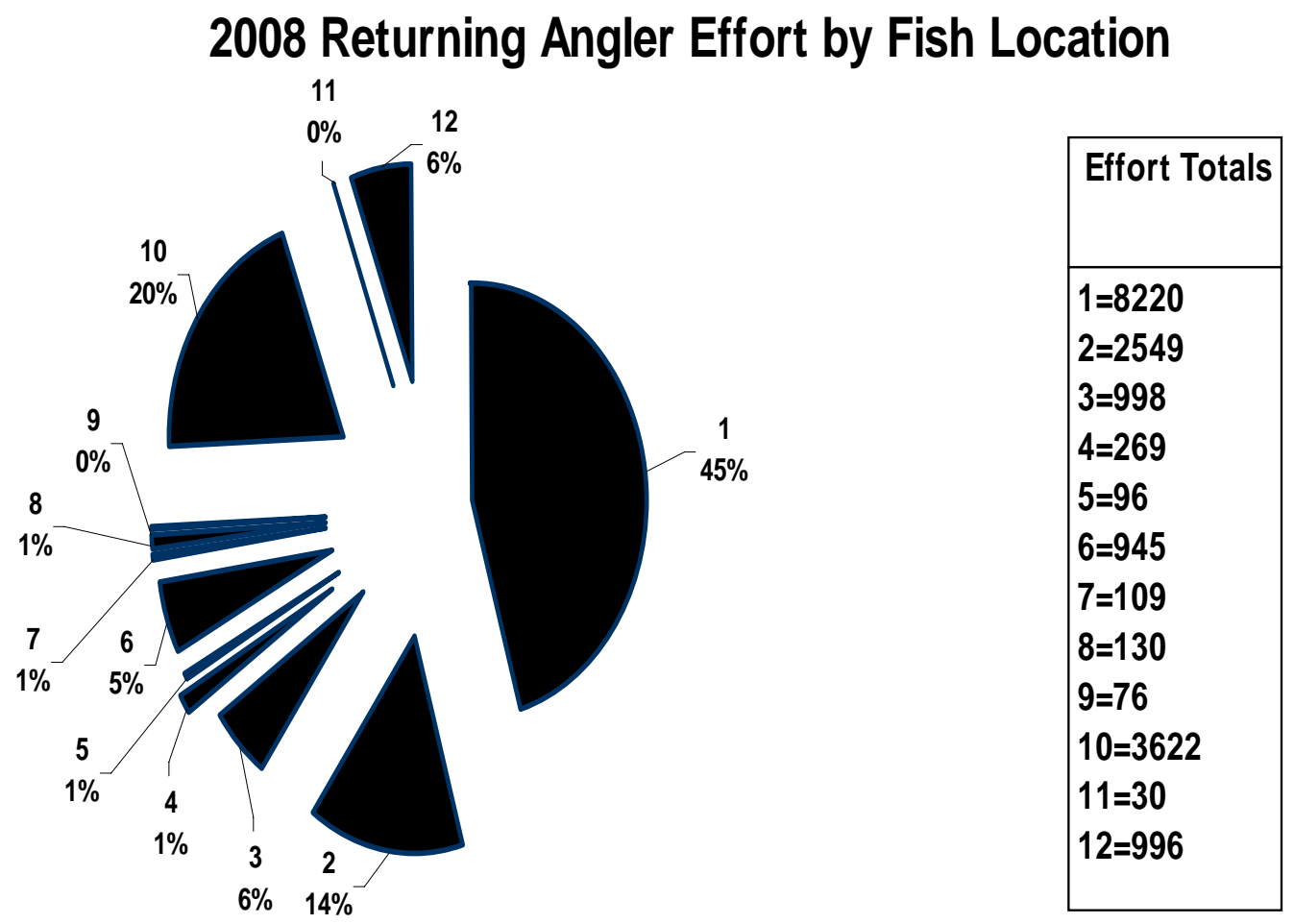

Figure 14. 2008 NPSRF Angler Effort by Fishing Location (returning anglers only).*

*Fishing Location Codes for Columbia River; 1 = Below Bonneville Dam, 2 = Bonneville Reservoir, 3 = The Dalles Reservoir, $4=$ John Day Reservoir, $5=$ McNary Dam to the mouth of the Snake River, $6=$ Mouth of the Snake River to Priest Rapids Dam. Fishing Location Codes for the Snake River; 7 = Mouth of the Snake River to Ice Harbor Dam, $8=$ Ice Harbor Reservoir, 9= Lower Monumental Reservoir, $10=$ Little Goose Reservoir, $11=$ Lower Granite Dam to the mouth of the Clearwater River, 12 = Mouth of the Clearwater River to Hell's Canyon Dam.

\section{Effort by Registration Station}

Mean effort per registration station during the 2008 NPSRF was 1,452 angler days compared to 1,584 angler days in 2007. Effort totals ranged from 4,020 angler days at the Boyer Part station to 303 angler days at the Lyons Ferry station (Figure 15). Effort during the 2008 NPSRF actually increased at nine of the seventeen registration stations, most notable at the Gleason, Washougal and Boyer stations. We saw the largest decline in effort (from 2007) at the Willow Grove station where we lost 613 angler days. 


\section{Effort By Registration Station}

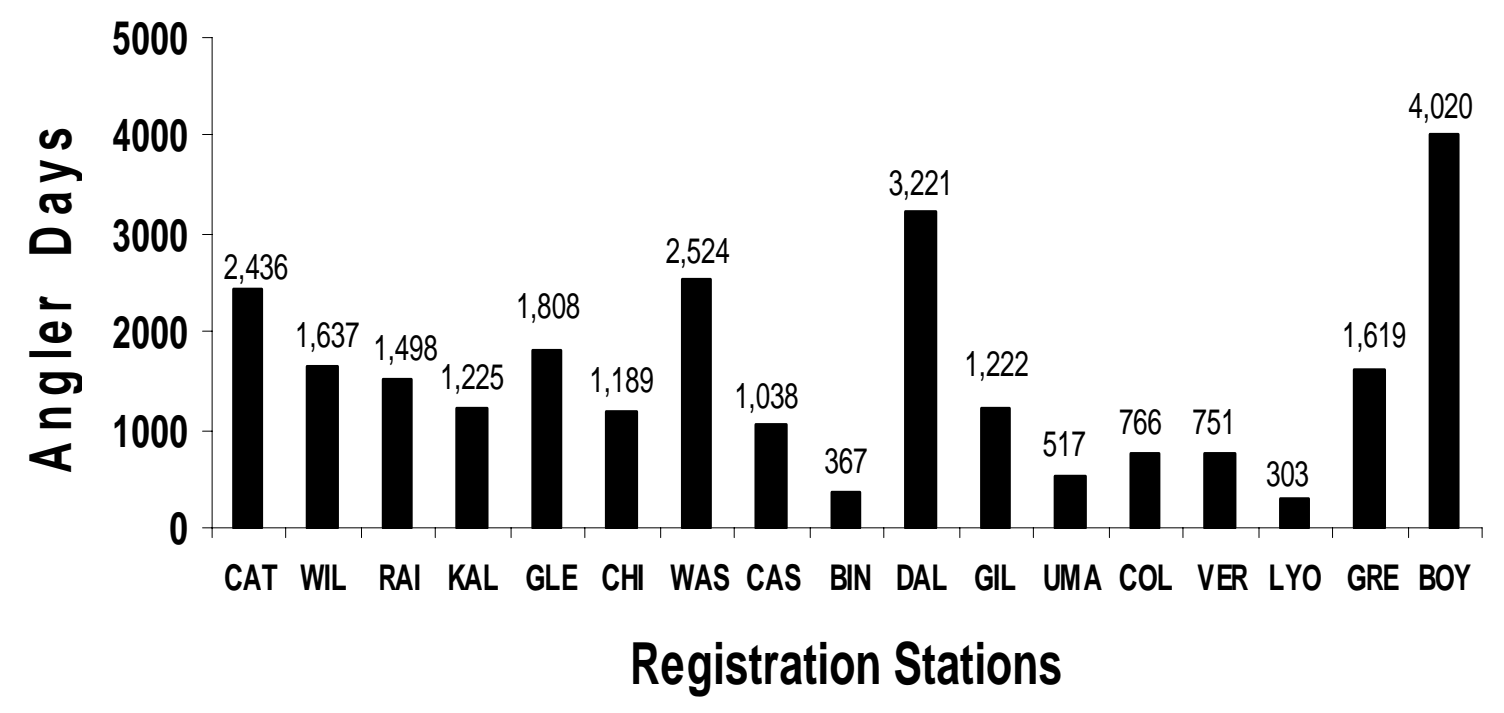

Figure 15. 2008 Northern Pikeminnow Sport-Reward Fishery Angler Effort by Registration Station. CAT-Cathlamet, WIL-Willow Grove, RAI-Rainier, KAL-Kalama, GLE-Gleason, CHI-Chinook, WAS-Washougal, CASCascade Locks, BIN-Bingen Marina, DAL-TheDalles, GIL-Giles French, UMA-Umatilla, COL-Columbia Point, VERVernita, LYO-Lyon's Ferry, GRE-Greenbelt, BOY-Boyer Park.

\section{Catch Per Angler Day (CPUE)}

The 2008 NPSRF recorded an overall (returning + non-returning anglers) catch per unit of effort (CPUE) of 6.11 northern pikeminnow harvested per angler day during the 2008 season. This catch rate declined from 7.15 in 2007, (Hone et al. 2007) and was the NPSRF's second consecutive year of declining CPUE (Figure 16). Angler CPUE had increased steadily throughout the NPSRF's history from 1991-2006, but 2008 CPUE is the worst since 1999 and the second straight year of decline. Part of this decline may be due to an influx of new or inexperienced anglers attracted to the SRF late in the year by the special Pikeminnow Angler Random Drawing incentive, although weekly CPUE rates discussed below do not seem to bear that out. Returning angler CPUE during the 2007 NPSRF was 8.86 northern pikeminnow per angler day, down from 10.50 in 2007. We estimate that CPUE for non-returning anglers is 0.04 reward sized northern pikeminnow per angler day based on 2008 NPSRF phone survey results. 


\section{CPUE -- Linear 1991-2008 Overall CPUE}

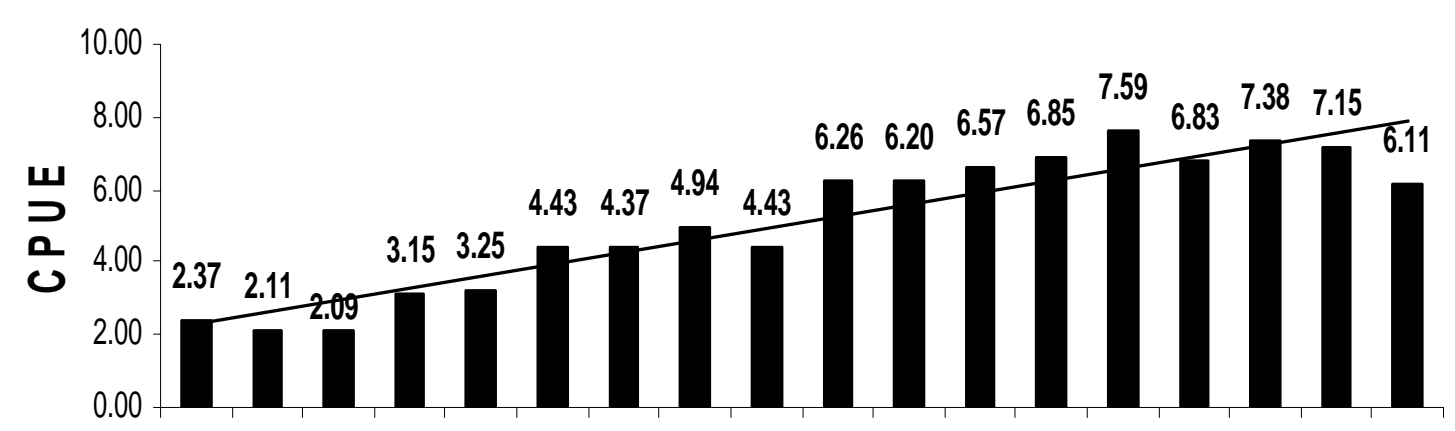

199119921993199419951996199719981999200020012002200320042005200620072008

Year

Figure 16. Annual NPSRF CPUE (returning + non-returning anglers) for the years 1991-2008.

\section{CPUE by Week}

Mean angler CPUE by week for the 2008 NPSRF was 6.49 fish per angler day compared to 7.49 in 2007. CPUE ranged from 2.24 in week 19 (May 5-May 11) to a peak of 11.68 in week 42 (October 13-19) (Figure 17). As expected, catch rates dropped in week 35 (when the special Pikeminnow Angler Random Drawing incentive began) as new or less experienced anglers who are less proficient at catching northern pikeminnow (Hisata et al. 1995) entered or returned to the NPSRF. Once the drawings were completed (week 39), CPUE again spiked upward during the season extension.

\section{CPUE By Week}

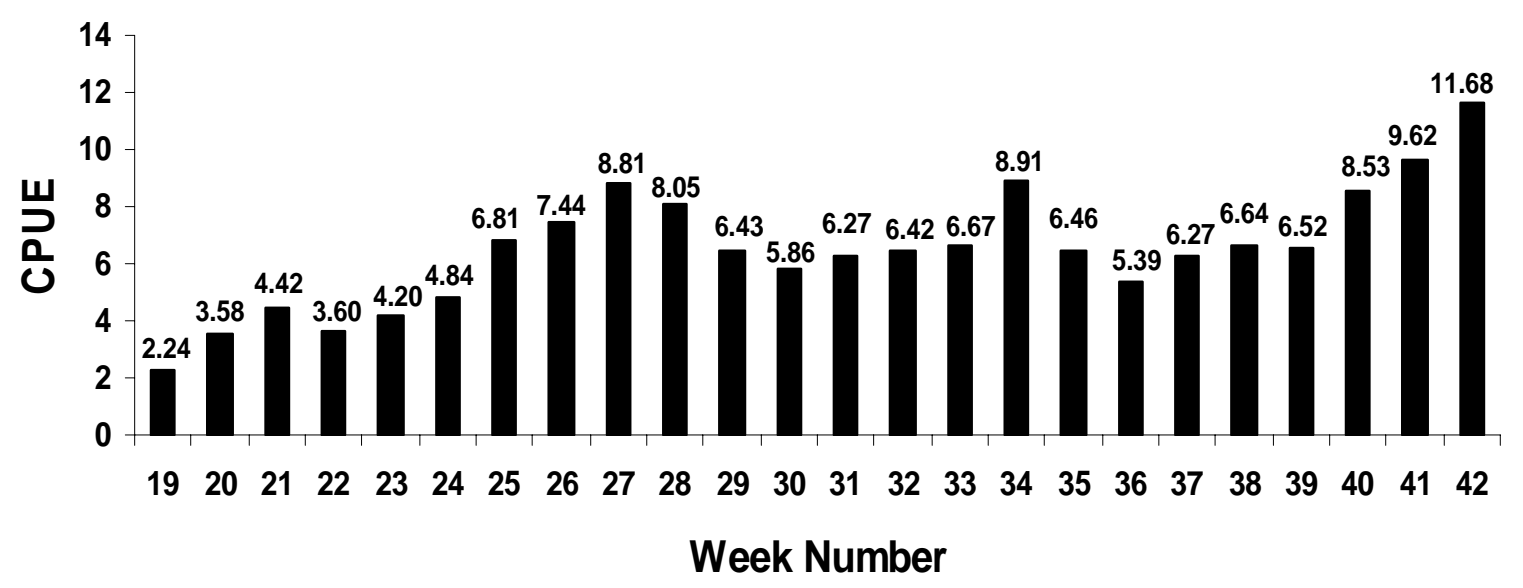

Figure 17. 2008 Northern Pikeminnow Sport-Reward Fishery Angler CPUE by Week. 


\section{CPUE by Fishing Location}

Angler success rates for the 2008 NPSRF (as indicated by CPUE) varied by Fishing Location and ranged from 13.37 fish per angler day in Fishing Location 08, Ice Harbor Reservoir to 1.93 fish per angler per day in fishing location 11 (Lower Granite Dam to the mouth of the Clearwater River ) (Figure 18). Catch rates were down at all fishing locations except Fishing Location 08, and rates for locations 10 and 12 remained similar to 2007. The average CPUE by fishing location was 7.70 northern pikeminnow per angler day.

\section{CPUE By Fishing Location}

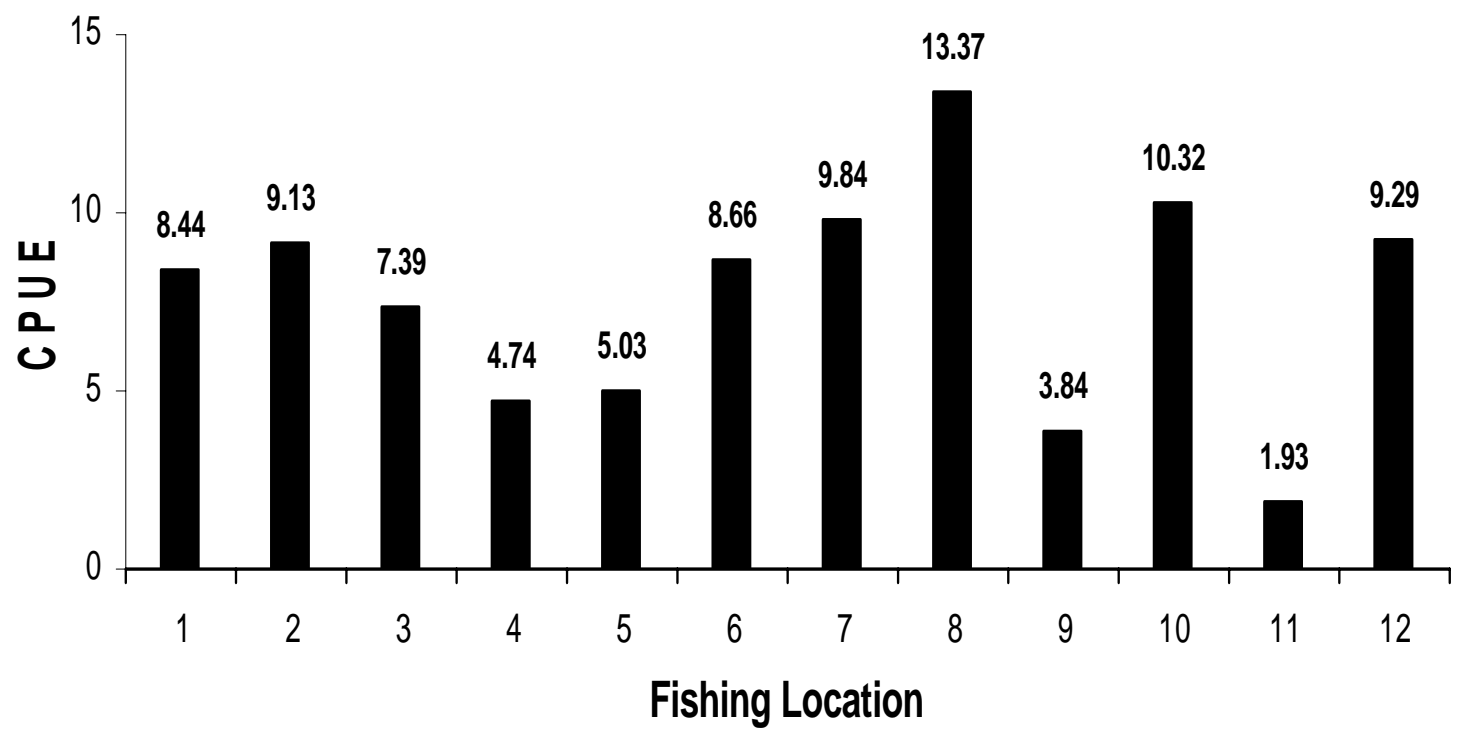

Figure 18. 2008 Northern Pikeminnow Sport-Reward Fishery Angler CPUE by Fishing Location.* *Fishing Location Codes for Columbia River; 1 = Below Bonneville Dam, $2=$ Bonneville Reservoir, 3 = The Dalles Reservoir, $4=$ John Day Reservoir, 5= McNary Dam to the mouth of the Snake River, $6=$ Mouth of the Snake River to Priest Rapids Dam. Fishing Location Codes for the Snake River; $7=$ Mouth of the Snake River to Ice Harbor Dam, 8 = Ice Harbor Reservoir, $9=$ Lower Monumental Reservoir, $10=$ Little Goose Reservoir, $11=$ Lower Granite Dam to the mouth of the Clearwater River, 12 = Mouth of the Clearwater River to Hell's Canyon Dam.

\section{CPUE by Registration Station}

The registration Station with the highest CPUE during the 2008 NPSRF was Boyer Park with 9.05 northern pikeminnow per angler day (Figure 19). The registration station with the lowest CPUE was the Willow Grove station with a CPUE of 2.98 northern pikeminnow per angler day. The station average for angler CPUE was 5.81. Anglers at eleven of the 17 registration stations had lower CPUE during the 2008 NPSRF than they did in 2007. The Giles French station had the largest change in CPUE dropping $45 \%$ to 6.26 (down from 11.38 in 2007). 


\section{CPUE By Registration Station}

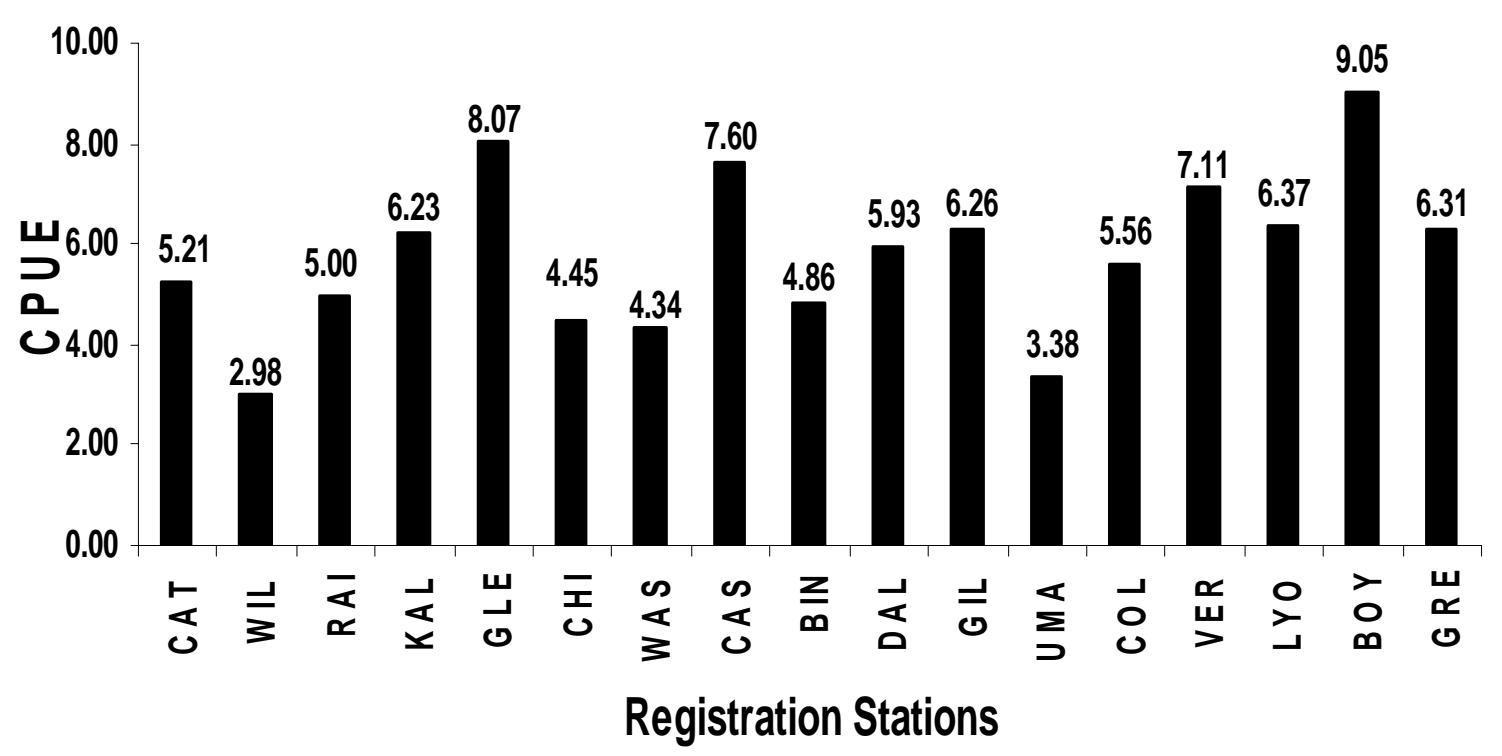

Figure 19. 2008 Northern Pikeminnow Sport-Reward Fishery Angler CPUE by Registration Station. CAT-Cathlamet, WIL-Willow Grove, RAI-Rainier, KAL-Kalama, GLE-Gleason, CHI-Chinook, WAS-Washougal, CAS-Cascade Locks, BIN-Bingen, DAL-TheDalles, GIL-Giles French, UMA-Umatilla Marina, COL-Columbia Point, VER-Vernita, LYO-Lyon's Ferry, GRE-Greenbelt, BOY-Boyer Park.

\section{Angler Totals}

There were 3,610 separate anglers who participated in the 2008 NPSRF, a decline of 204 participants from 2007 (Hone et al. 2007). One thousand, three hundred and eighteen of these anglers $(36.5 \%)$ were classified as successful since they harvested at least one reward size northern pikeminnow (for which a voucher was issued) during the 2008 season. Of the successful anglers, 75.4\% (994 anglers) sent in their vouchers to PSMFC for payment (Russell Porter, PSMFC personal communication). The average successful angler harvested 121 northern pikeminnow during the $2008 \mathrm{NPSRF}$, although when we break down the 1,318 successful anglers by tier, most anglers $(84 \%=1,104$ anglers $)$ harvested fewer than 100 northern pikeminnow and were classified as Tier 1 anglers (Figure 20). One hundred and ten anglers (8\%) reached Tier 2 status by harvesting between 101 and 400 northern pikeminnow, and 104 anglers (8\%) reached Tier 3 status by harvesting more than 400 northern pikeminnow in 2008 . The 104 anglers who reached Tier 3 also represent only $2.9 \%$ of all angler participants (both returning and non-returning anglers) during the 2008 NPSRF. The number of anglers reaching each of the three tiers during the 2008 NPSRF was once again down at all three levels compared to the previous year. The number of anglers at Tier one ( $<100$ fish) declined by 160 anglers, Tier 2 lost 44 anglers, and Tier 3 lost 20 anglers. 


\section{Percent of NPSRF Anglers by Tier}

Tier $2=110$

Anglers

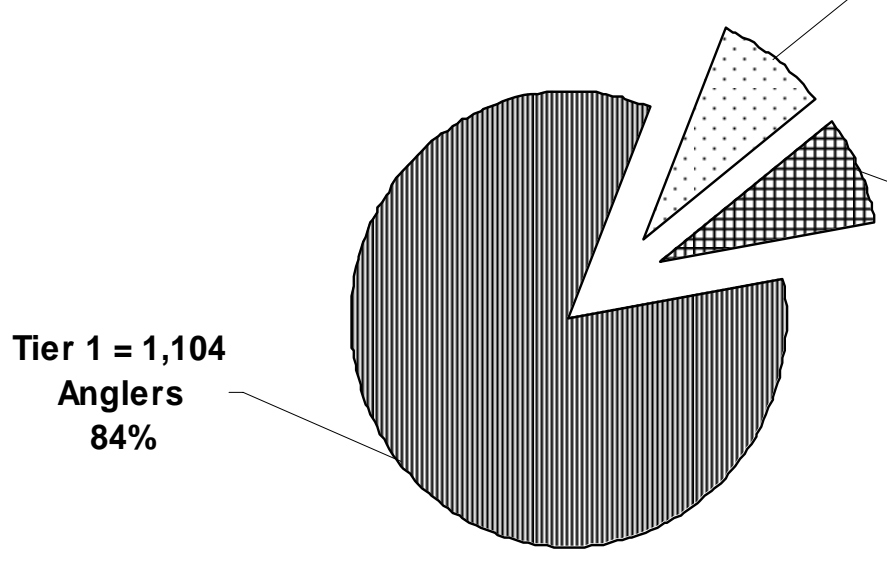

$8 \%$

Tier $3=104$

Anglers

$8 \%$

Figure 20. 2008 NPSRF Anglers by tier (returning only) based on total \# of fish harvested.

While Tier 1 anglers made up more than $80 \%$ of all successful NPSRF participants in 2008, they only harvested an average of 12 fish per angler, per year, accounting for only 8\% (13,532 northern pikeminnow) of total NPSRF harvest (Figure 21). Tier 2 anglers harvested an average of 215 fish per year, equaling 15\% (23,699 northern pikeminnow) of total 2008 NPSRF harvest. Tier 3 anglers, also known as "highliners", harvested an average of 1,179 fish per year equaling $77 \%$ (122,575 northern pikeminnow) of total 2008 NPSRF harvest. The percentage of total harvest for both Tier 1 and Tier 2 anglers declined slightly from 2007, while the percentage for Tier 3 anglers improved.

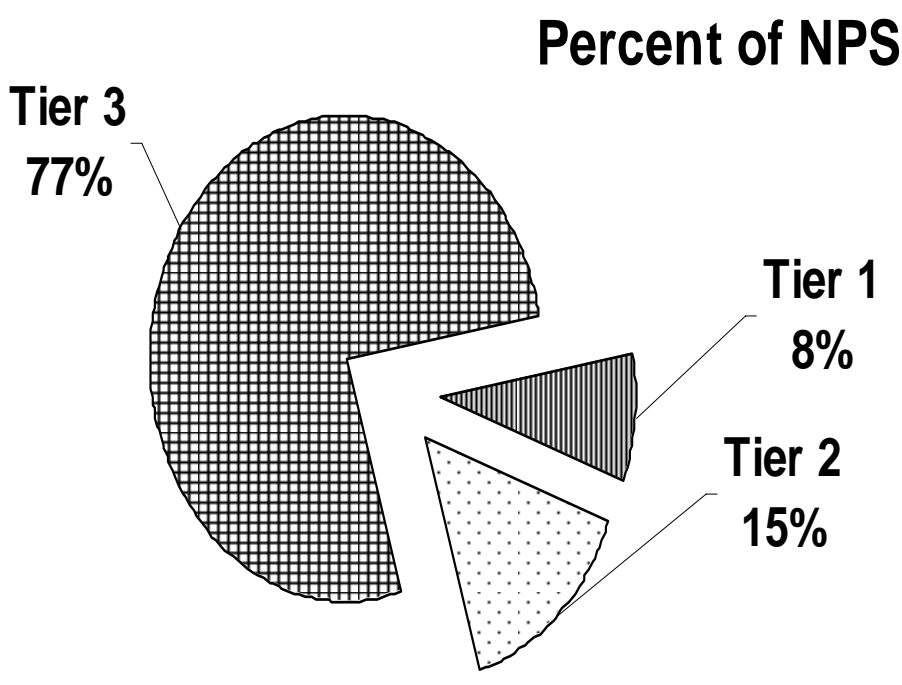

Figure 21. 2008 NPSRF Harvest by Angler Tier (Tier $1=<100$, Tier $2=101-400$, Tier $3=>400$ ). 
The average NPSRF participant (returning + non-returning anglers) expended slightly more time (effort) pursuing northern pikeminnow during the 2008 season than in 2007 (7.24 vs. 7.1 angling days of effort). Tier 1 anglers spent the same average number of days fishing in the 2008 NPSRF ( 7 days) as in 2007 (Figure 22). Tier 2 anglers increased the average number of days that they spent fishing for northern pikeminnow from 35 in 2007 to 46 in 2008. Tier 3 anglers increased their average number of days spent fishing during the 2008 NPSRF even more, going from 79 days in 2007 to 90 days in 2008. This continues the trend seen in recent seasons where the NPSRF anglers who harvest the most fish (Tier 2 and 3 anglers), also expend the most effort.

\section{Days Average Effort by Tier}

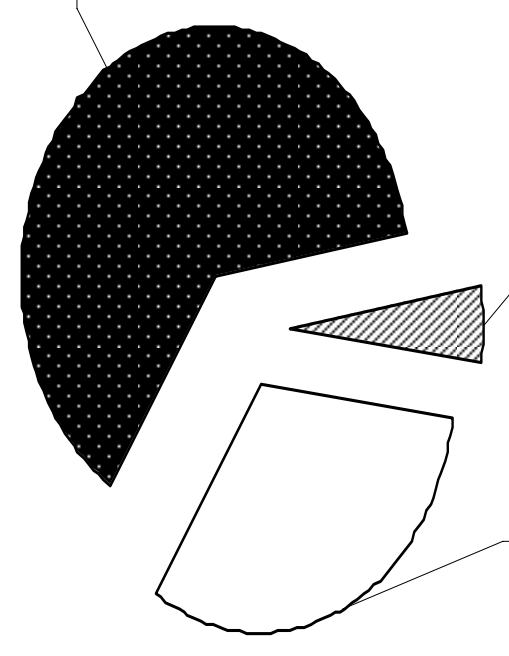

7Days

圂 Tier 1

$\square$ Tier 2

Tier 3

46Days

Figure 22. Average Effort of 2008 NPSRF Anglers by Tier (Tier $1=<100$, Tier $2=101-400$, Tier $3=>400$ ) .

Just as overall angler CPUE for the 2008 NPSRF decreased from 2007, CPUE decreased for all anglers at all tier levels (Figure 23). CPUE for anglers at Tier 1 decreased from 2.0 in 2007 to 1.68 in 2008. CPUE for Tier 2 anglers decreased from 5.62 in 2007 to 4.72 in 2008. CPUE for Tier 3 anglers declined the most, dropping from 14.95 in 2007 to 13.04 in 2008. 


\subsection{4}

\section{CPUE by Tier}

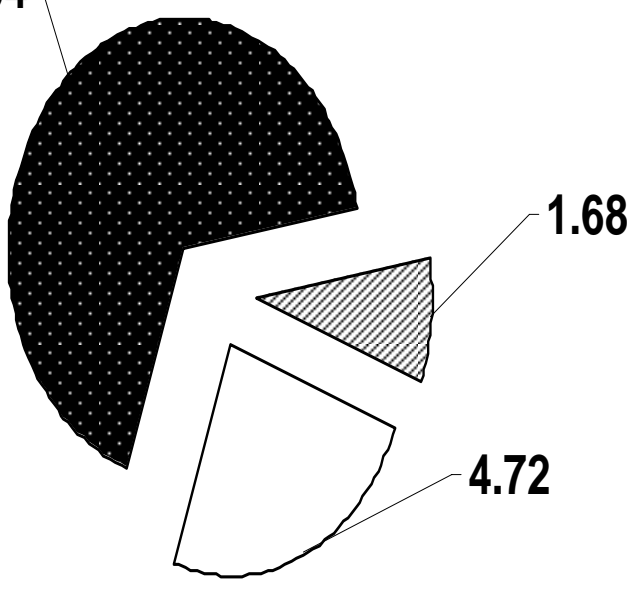

圆 Tier 1

$\square$ Tier 2

Tier 3

Figure 23. Average CPUE of 2008 NPSRF Anglers by Tier (Tier $1=<100$, Tier $2=101-400$, Tier $3=>400$ ).

The top angler (based on number of fish caught) for the 2008 NPSRF harvested 7,015 NPM worth an estimated $\$ 57,772$. This total included 6 spaghetti tagged northern pikeminnow and was 1,839 more fish than the number two angler harvested. It was also more than 1,200 more fish than the same angler caught (as the 2007 top angler) during the previous season $(5,778$ northern pikeminnow). The total harvest by the top angler for the 2008 NPSRF is also currently recognized as the single season record for any angler's harvest, in NPSRF history. The CPUE for this year's top angler was 52.4 fish per angler day (down from the same angler's 2007 CPUE of 57.2). The top angler did spend more days of effort during the 2008 season than the same angler did in 2007 (134 days in 2008 versus 101 days in 2007), accounting for the higher total harvest. By comparison, the top angler (in terms of participation) for the 2008 NPSRF fished 161 days and harvested 325 northern pikeminnow.

\section{Tag Recovery}

\section{Northern Pikeminnow Tags}

Returning anglers harvested 167 northern pikeminnow tagged by ODFW with external spaghetti tags during the 2008 NPSRF compared to 170 spaghetti tags paid in 2007 (Hone et al., 2007). Tag recoveries peaked in week 26, one week prior to peak NPSRF harvest (Figure 24). Of these spaghetti tagged northern pikeminnow, 166 had also been PIT tagged by ODFW as a secondary mark (1 fish did not receive a PIT tag when it was looped-tagged by ODFW or was not detected). WDFW technicians also recovered an additional 123 northern pikeminnow having PIT tags with wounds and/or fin-clips indicating that the fish had "lost" an ODFW spaghetti tag. The recovered spaghetti and PIT tags, as well as the potential tag loss data was estimated by 
ODFW to equal a $19.5 \%$ exploitation rate for the 2008 NPSRF (ODFW, personal communication).

\section{Spaghetti Tag Recoveries by Week}

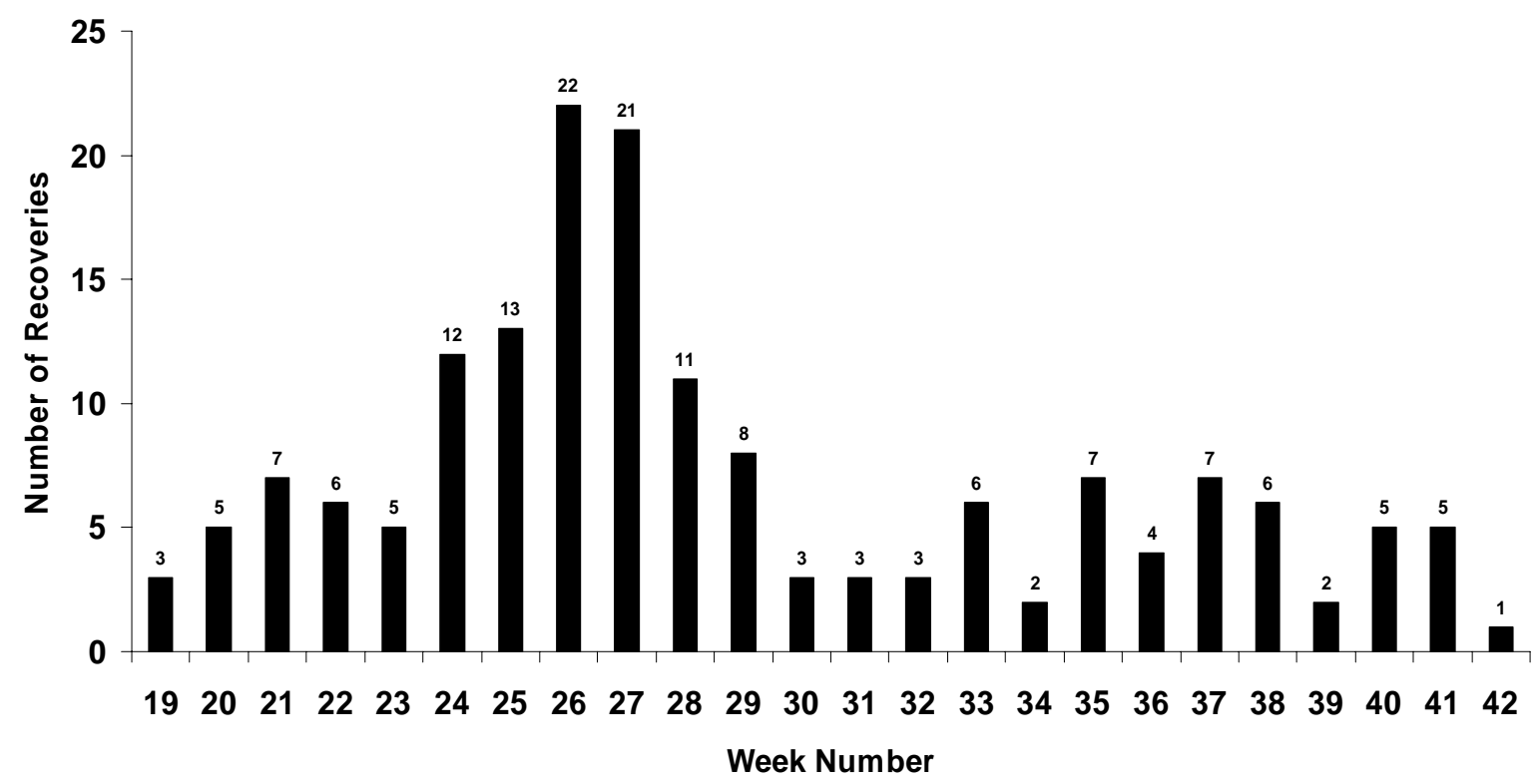

Figure 24. 2008 NPSRF Spaghetti Tag Recoveries by Week.

\section{Ingested Tags}

A total of 159,806 northern pikeminnow were individually scanned for the presence of PIT tags. This represents 100\% of the total harvest of reward-size fish for the 2008 NPSRF (northern pikeminnow not qualifying for rewards were also scanned whenever possible). We recovered a total of 107 PIT tags from consumed smolts that had been ingested by northern pikeminnow harvested during the $2008 \mathrm{NPSRF}$, an overall occurrence ratio of 1:1,494. Total ingested tag recoveries in 2008 were higher ( 5 more) than the previous year and with lower season harvest, the result was a higher rate of occurrence (1:1,494 in 2008 versus 1:1,887 in 2007) (Hone et al., 2007). PIT tag recoveries of salmonid smolts ingested by northern pikeminnow peaked during early July in 2008 and as in previous years, recoveries of PIT tags from ingested smolts ended by early August (Figure 25). 


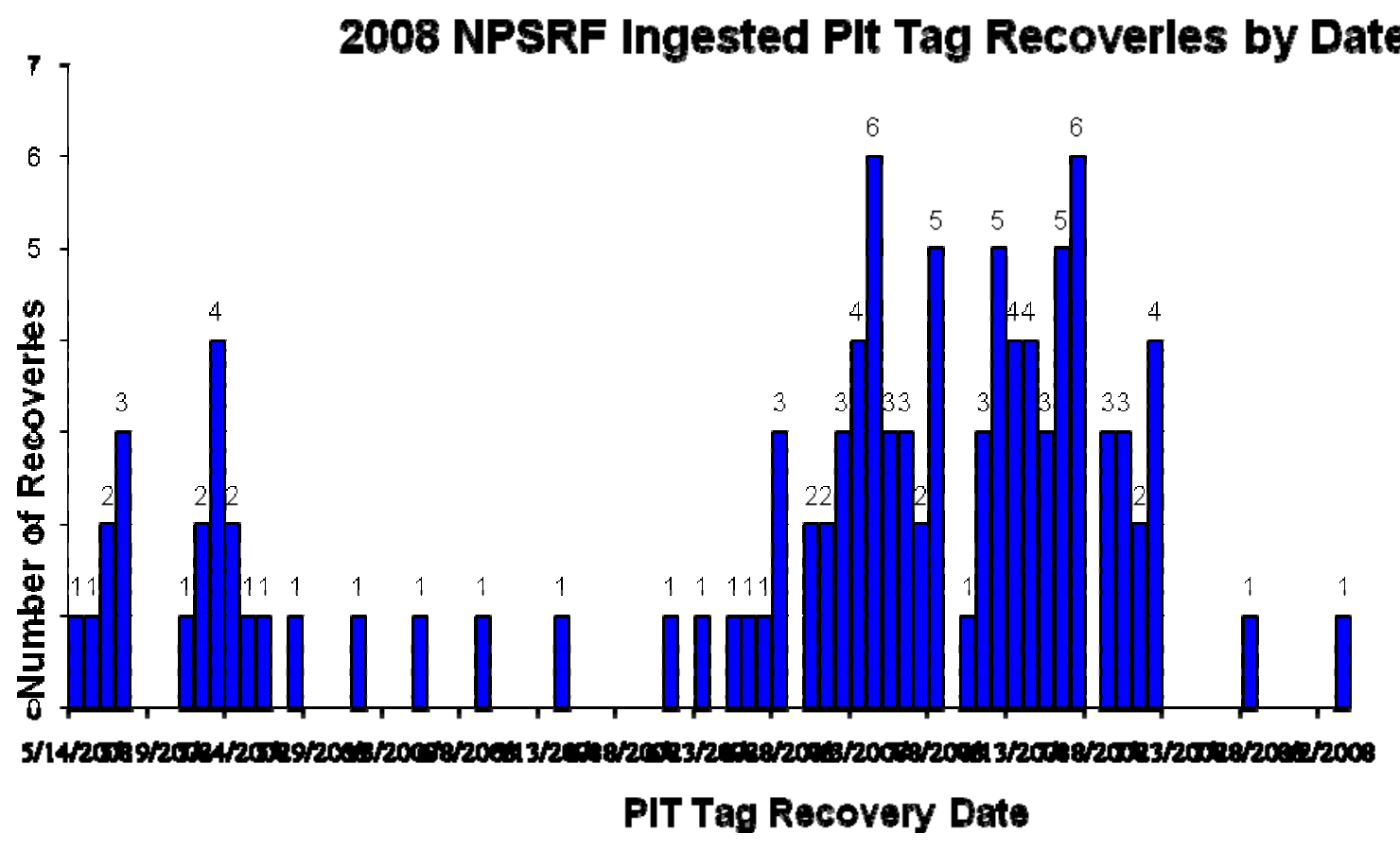

Figure 25. 2008 NPSRF PIT Tag Recoveries by Date.

Pit tag recoveries by fishing location showed that northern pikeminnow harvested from Fishing location 10 during the 2008 NPSRF, had ingested the largest number of salmonid smolts containing PIT tags (Figure 26). This is a change from the past two years where the highest number of recoveries came from The Dalles, and Bonneville Pools (Fishing locations 01 and 02).

\section{NPSRF Ingested PIT Tag Recoveries}

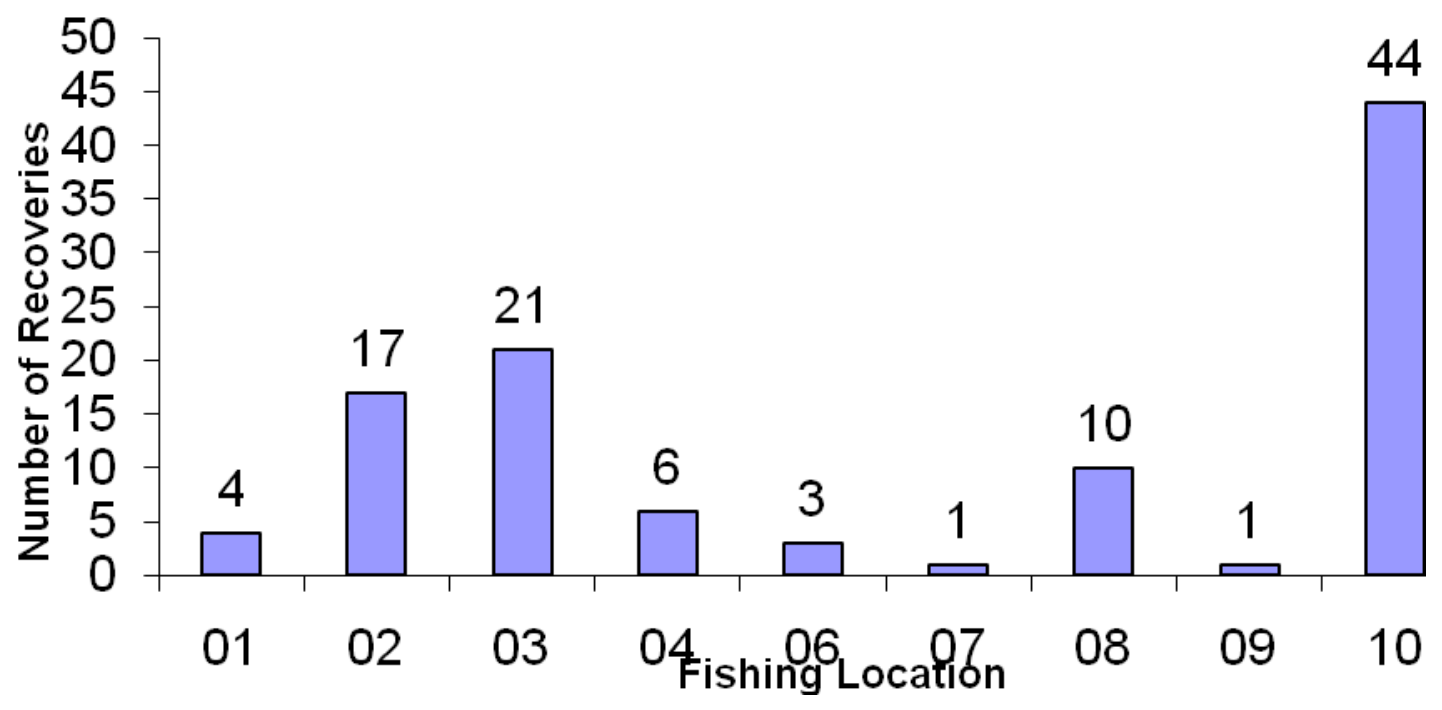

Figure 26. 2008 NPSRF ingested PIT Tag Recoveries by Fishing Location. 
Species composition of PIT tagged smolts recovered from northern pikeminnow harvested in the 2008 NPSRF indicated that they were overwhelmingly chinook smolts (primarily fall chinook) (Figure 27). 94 of the 107 ingested PIT tag recoveries (88\%) were from chinook smolts, and 13 PIT tags were listed as "not given species" in PTAGIS accounting for the remaining $12 \%$. PIT tag queries of PTAGIS also indicated that 11 of the 94 chinook smolts $(11.7 \%)$ were of wild origin.

\section{Ingested Salmonids - 2008 NPSRF}

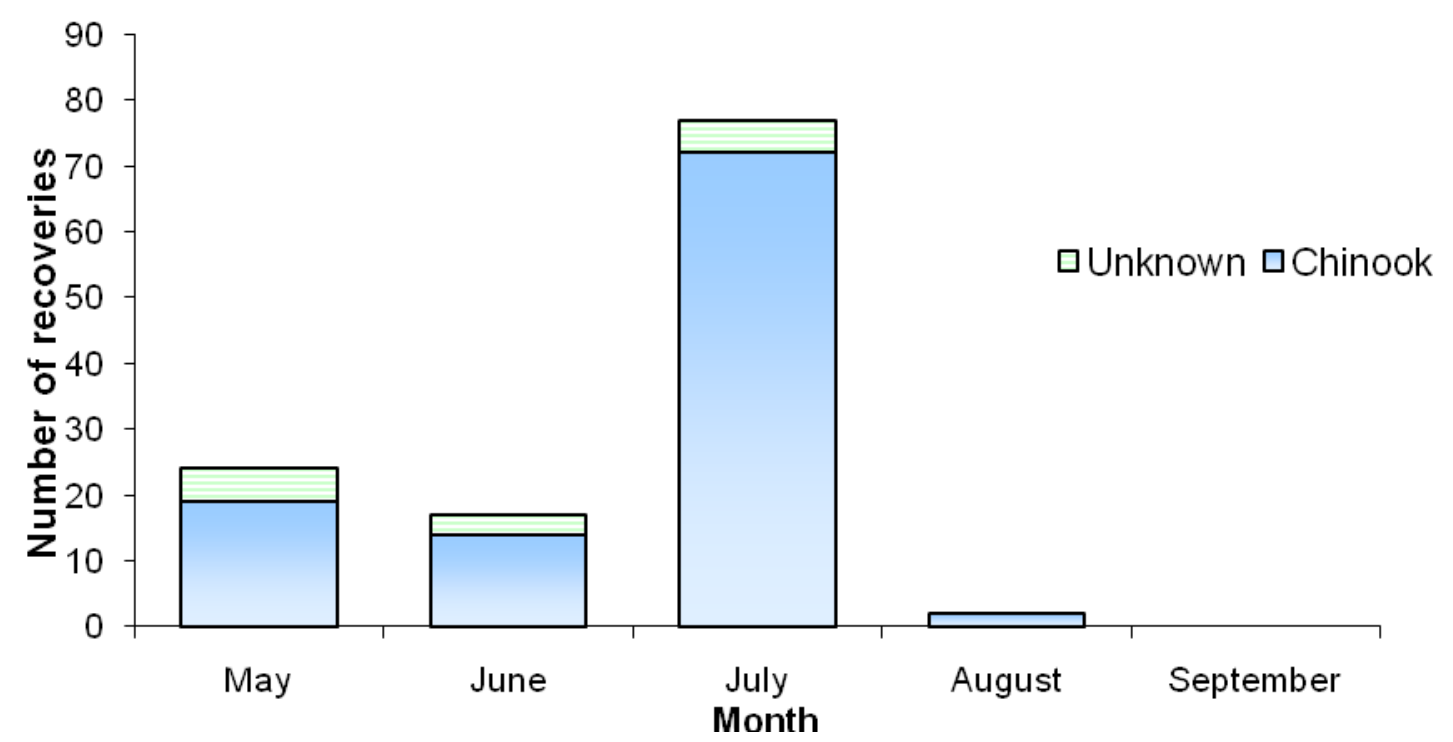

Figure 27. Recoveries of ingested salmonid PIT Tags from the 2008 NPSRF.

Analysis of PIT tag recovery data from the 2008 NPSRF continues to document northern pikeminnow predation on downstream migrating juvenile salmonids, mainly chinook salmon and primarily fall chinook. Our PIT tag recovery data also confirms that northern pikeminnow consumed chinook smolts most heavily during their peak smolt migration month of July. Further data collection and analysis of PIT tag recoveries from juvenile salmonids consumed by northern pikeminnow harvested in the NPSRF may lead to a better understanding of northern pikeminnow predation on salmonid smolts and the factors affecting the vulnerability of smolts to predation while migrating through the Columbia River System. 


\section{SUMMARY}

The 2008 NPSRF succeeded in reaching the NPMP's 10-20\% exploitation goal for the eleventh consecutive year, achieving an estimated exploitation rate of 19.5\%. Despite NPSRF harvest falling to its lowest level since 1999, the high exploitation rate ensured program success. In fact, this was also the highest exploitation rate in NPSRF history. Effort declined by only 783 angler days from 2007 after dropping more than 4,000 angler days from the previous year. Likewise, there were only 204 less individuals participating in 2008 versus 2007. The special Pikeminnow Angler Random Drawing incentive definitely attracted anglers to the 2008 NPSRF and likely kept losses in participation and harvest from being worse than they were. Since angler CPUE dropped overall, and at all tier levels, the most likely reason for lower harvest and effort during 2008 was probably just poorer overall fishing conditions.

The NPSRF's top angler for the 2008 season was also the top angler from the 2007 season, although he caught 1,200 more fish in 2008 than in 2007. The top angler participated more in 2008 than in 2007 and also thus had lower CPUE, following the overall trend for the 2008 NPSRF. The average successful angler caught an average of 4 less fish per year in 2008 than in 2007, and also fished slightly more days. In the end, lower angler CPUE at all tier levels resulted in below average annual harvest for the 2008 NPSRF, however this did not seem to have a negative effect on achieving the NPSRF's primary goal of reaching a 10-20\% exploitation rate as indicated by the record setting 2008 exploitation rate.

Detection of PIT tags from juvenile salmonids ingested and retained in the gut of northern pikeminnow, continues to yield valuable data about northern pikeminnow predation on juvenile salmonid smolts. We recovered more PIT tags than last year and peak recoveries occurred later in the year. Species composition of PIT tag recoveries from ingested juvenile salmonids showed that they were exclusively chinook smolts, mostly of hatchery origin. We did not recover any identifiable PIT tags from steelhead or any other species. Use of PIT tags by ODFW as a secondary mark in spaghetti tagged northern pikeminnow continues to go smoothly and we look forward more accurate estimates of tag loss and overall pikeminnow exploitation by the NPSRF. PIT tag recoveries also continued to be monitored to identify and document angler fraud from northern pikeminnow tagged outside NPSRF boundaries. 


\section{RECOMMENDATIONS FOR THE 2009 SEASON}

1.) Begin implementation of the 2008 NPSRF for all registration stations on May $1^{\text {st }}$ in order to enhance NPSRF promotional opportunities and maximize predation reduction by beginning removals earlier in the period of smolt outmigration.

2.) Adjust Washougal registration station times based on success of Ridgefield station trial (from 2008) so that Ridgefield will be open 10:30-12:30 and Washougal will be open from 1:30-7:00pm daily in order to increase angler participation and/ or NPSRF efficiency.

3.) Review NPSRF Rules of participation as needed, adjusting to the dynamics of the fishery and fishery participants, in order to maintain NPSRF integrity.

4.) Develop angler education materials designed to recruit new anglers to NPSRF, and to improve the angling efficiency of current participants in order to achieve the NPMP's 10$20 \%$ exploitation goal.

5.) Retain the option to extend the NPSRF season on a site-specific basis if warranted by high harvest, angler effort, and/or CPUE levels.

6.) Continue to scan all northern pikeminnow for PIT tags from ingested juvenile salmonids, from northern pikeminnow tagged by ODFW as part of the biological evaluation of the NPMP, and as a way to deter fraud by identifying fish from outside NPSRF boundaries.

7.) Survey $20 \%$ of non-returning anglers to record total non-returning angler catch of all salmonids to estimate total non-returning angler catch and harvest per NPMP protocol.

8.) Continue to investigate additional incentives for anglers to harvest northern pikeminnow from within NPSRF boundaries, i.e., spaghetti tagged fish. 


\section{ACKNOWLEDGEMENTS}

This project is funded by the Bonneville Power Administration (BPA), William Maslen, Project Manager and John Skidmore, COTR (Contract DE-BI719-94BI24514). We thank Carlene Stenehjem at BPA-Public Affairs; Erick Van Dyke and his staff at the Oregon Department of Fish and Wildlife (ODFW); and Russell Porter and his staff at the Pacific States Marine Fisheries Commission (PSMFC) for their coordination.

We are grateful to the City of Rainier for the use of the Rainier boat ramp; The City of Richland for the use of Columbia point Park; the Cowlitz County Parks and Recreation Department for the use of the Willow Grove boat ramp; The Port of Camas/Washougal for the use of the Camas/Washougal boat ramp; the Port of Cathlamet for the use of the Cathlamet Marina; the Port of Ridgefield for the use of the Ridgefield boat ramp; the Port of Kalama for the use of the Kalama Marina; the Port of The Dalles for the use of The Dalles Boat Basin; the Port of Cascade Locks for the use of Marine Park; the Port of Umatilla for the use of the Umatilla Marina; the Portland Regional Parks Department for the use of the M.J. Gleason Boat Ramp and Chinook Landing; the U.S. Army Corps of Engineers for the use of Giles French Park, and the Greenbelt Boat Ramp; the Port of Bingen for the use of Bingen Marina; the Washington Department of Transportation for the use of the Vernita Bridge Rest Area; Rod and Sharon Bailey for the use of Lyon's Ferry Marina; and Dave and Linda Petersen for the use of Boyer Park.

We appreciate the efforts of Melissa Baier, Beverly Buitenbos, Dick Buitenbos, Bill Fleenor, Leif Fox, Roger Fox, Steve Gross, Travis Harwood, Maria Holmes, Jeff Lesselyoung, Jon McMullin, Eric Meyer, Linda Moore, Janice Pletcher, Lauren Ridenour, Cole Shelton, Mark, Southern, Jason Swindle, Robert Warrington, Alyce Wells, and Dennis Werlau for operating the sport-reward fishery registration stations.

We also recognize Diana Murillo for her excellent work in computer data entry and document verification, Fella Tanaka for her numerous phone survey interviews, Kathleen Moyer for serving as the lead technician for the PIT tag recovery portion of the program, as well as Melissa Dexheimer for producing our weekly field activity reports, overseeing the Sport-Reward hotline, and helping to keep the program operating smoothly throughout the season. 


\section{REFERENCES}

Bruce, R.C., E.C. Winther, J.D. Hone, and P.V. Dunlap. 2005. Implementation of the northern pikeminnow sport-reward fishery in the Columbia and Snake Rivers. In Development of a system-wide predator control program: stepwise implementation of a predator index, predator control fisheries, and evaluation plan in the Columbia River Basin (Northern Pikeminnow Management Program). 2005 Annual Report, project number 90-077. Contract DE-B179-90BP07084, Bonneville Power Administration, Portland, OR.

Burley, C.C., D.C. Klaybor, G.W. Short, and G.J. Hueckel. 1992. Evaluation of the northern squawfish sport-reward fishery in the Columbia and Snake Rivers. Report B in C.F. Willis and A.A. Nigro, editors. Development of a system-wide predator control program: stepwise implementation of a predator index, predator control fisheries, and evaluation plan in the Columbia River Basin (Northern Pikeminnow Management Program). 1991 Annual Report. Contract DE-B179 -90-BP07084, Bonneville Power Administration, Portland, Oregon.

Fox, L.G., J.J. Amren, B.G. Glaser, M.L. Wachtel, and E.C. Winther. 1999. Implementation of the northern pikeminnow sport-reward fishery in the Columbia and Snake Rivers. In Development of a system-wide predator control program: stepwise implementation of a predator index, predator control fisheries, and evaluation plan in the Columbia River Basin (Northern Pikeminnow Management Program). 1999 Annual Report, project number 90-007. Bonneville Power Administration, Portland, Oregon.

Friesen, T.A., and D.L. Ward 1999. Management of northern pikeminnow and implications for juvenile salmonid survival in lower Columbia and Snake Rivers. North American Journal of Fisheries Management 19:406-420.

Glaser, B.G., J.J. Amren, L.G. Fox., M.L. Wachtel, and E.C. Winther. 2000. Implementation of the northern pikeminnow sport-reward fishery in the Columbia and Snake Rivers. In Development of a system-wide predator control program: stepwise implementation of a predator index, predator control fisheries, and evaluation plan in the Columbia River Basin (Northern Pikeminnow Management Program). 2000 Annual Report, project number 90-077. Bonneville Power Administration, Portland, Oregon.

Hankin, D.G., and J. Richards. 2000. The northern pikeminnow management program: an independent review of program justification, performance, and cost effectiveness. Report to the Pacific Northwest Electric Power and Conservation Planning Council, Portland, Oregon.

Hisata, J.S., M.R. Peterson, D.R. Gilliland, E.C. Winther, S.S. Smith, and J. Saurez-Pena. 1995. Implementation of the northern squawfish sport-reward fishery in the Columbia and Snake Rivers. Report A in Development of a system-wide predator control program: stepwise implementation of a predator index, predator control fisheries, and evaluation 
plan in the Columbia River Basin (Northern Squawfish Management Program). 1995 Annual Report, project number 90-077. Contract DE-B179-90BP07084, Bonneville Power Administration, Portland, Oregon.

Hone, J.D., R. Bruce, E.C. Winther, and J. Memarian. 2003. Implementation of the northern pikeminnow sport-reward fishery in the Columbia and Snake Rivers. In Development of a system-wide predator control program: stepwise implementation of a predator index, predator control fisheries, and evaluation plan in the Columbia River Basin (Northern Pikeminnow Management Program). 2003 Annual Report, project number 90-077. Contract DE-B179-90BP07084, Bonneville Power Administration, Portland, Oregon.

Hone, J.D., R. Bruce, J. Memarian, and E.C. Winther. 2004. Implementation of the northern pikeminnow sport-reward fishery in the Columbia and Snake Rivers. In Development of a system-wide predator control program: stepwise implementation of a predator index, predator control fisheries, and evaluation plan in the Columbia River Basin (Northern Pikeminnow Management Program). 2004 Annual Report, project number 90-077. Contract DE-B179-90BP07084, Bonneville Power Administration, Portland, Oregon.

Hone, J.D., E. Winther, P. Dunlap, and K.C. Moyer. 2007. Implementation of the northern pikeminnow sport-reward fishery in the Columbia and Snake Rivers. In Development of a system-wide predator control program: stepwise implementation of a predator index, predator control fisheries, and evaluation plan in the Columbia River Basin (Northern Pikeminnow Management Program). 2007 Annual Report, project number 90-077. Contract DE-B179-90BP07084, Bonneville Power Administration, Portland, Oregon.

Klaybor, D.C., C.C. Burley, S.S. Smith, E.N. Mattson, E.C. Winther, P. E. DuCommun, H.R. Bartlett, and S,L. Kelsey. 1993. Evaluation of the northern squawfish sport-reward fishery in the Columbia and Snake Rivers. Report B in C.F. Willis and D. L. Ward, editors. Development of a system-wide predator control program: stepwise implementation of a predator index, predator control fisheries, and evaluation plan in the Columbia River Basin. 1993 Annual Report, Volume 1. Contract DE-B179-90BP07084, Bonneville Power Administration, Portland, Oregon.

Nelson, J. S. and five co-authors. 1998. Recommended changes in common fish names: pikeminnow to replace squawfish. Fisheries 23(9):37.

Normandeau A, J.R. Skalski, and I Mid Columbia Consulting. 2005. Evaluation of the spillway diversion wall on survival and injury of juvenile Chinook salmon at The Dalles Dam, spring 2004. Report prepared for the U.S. Army Corps of Engineers, Portland District, Portland, OR.

Northwest Power Planning Council. 1987a. Columbia River Basin Fish and Wildlife Program. Northwest Power Planning Council. Portland, Oregon.

Rieman, B.E., R. C. Beamsderfer, S. Vigg, and T.P. Poe. 1991. Predation by resident fish on 
juvenile salmonids in a mainstem Columbia reservoir: Part IV. Estimated total loss and mortality of juvenile salmonids to northern squawfish, walleye, and smallmouth bass. T. P. Poe, and B.E. Rieman editors. Resident fish predation on juvenile salmonids in John Day Reservoir, 1983-1986. Final Report (Contracts DE-A179-82 BP34796 and DE-A179-82BP35097) to Bonneville Power Administration, Portland, Oregon.

Rieman, B.E., and R.C. Beamesderfer. 1990. Dynamics of a northern squawfish population and the potential to reduce predation on juvenile salmonids in a Columbia River reservoir. North American Journal of Fisheries Management 10:228-241.

Smith, S.E., D.R. Gilliland, E.C. Winther, M.R. Petersen, E.N. Mattson, S.R. Kelsey, J. SuarezPena, and J. Hisata. 1994. (Implementation of the northern squawfish sport-reward fishery in the Columbia and Snake Rivers. In Development of a system-wide predator control program: Evaluation of the northern squawfish sport-reward fishery in the Columbia and Snake Rivers. Washington Department of Fish and Wildlife, Contract number DE-B179-90BP07084. 1994 Annual Report to the Bonneville Power Administration, Portland, Oregon.

Vigg, S. and C.C. Burley. 1989. Developing a predation index and evaluating ways to reduce salmonid losses to predation in the Columbia Basin. Report A in A.A. Nigro, editor. Developing a predation index and evaluating ways to reduce losses to predation in the Columbia Basin. Oregon Department of Fish and Wildlife, Contract Number DE-A17988BP92122. Annual Report to Bonneville Power Administration, Portland, Oregon.

Vigg, S., C.C. Burley, D.L. Ward, C. Mallette, S. Smith, and M. Zimmerman. 1990. Development of a system-wide predator control program: Stepwise implementation of a predation index, predator control fisheries, and evaluation plan in the Columbia River Basin. Oregon Department of Fish and Wildlife, Contact number DE-B179-90BP07084. 1990 Annual Report to the Bonneville Power Administration, Portland, Oregon.

Winther, E.C., J.S. Hisata, M.R. Peterson, M.A. Hagen and R. C. Welling. 1996. Implementation of the northern squawfish sport-reward fishery in the Columbia and Snake Rivers. In Development of a system-wide predator control program: stepwise implementation of a predator index, predator control fisheries, and evaluation plan in the Columbia River Basin (Northern Squawfish Management Program). 1996 Annual Report, project number 90-077. Contract DE-B179-90BP07084, Bonneville Power Administration, Portland, Oregon.

Winther, E.C., L.G. Fox, M.L. Wachtel, and B.G. Glaser. 2001. Implementation of the northern pikeminnow sport-reward fishery in the Columbia and Snake Rivers. In Development of a system-wide predator control program: stepwise implementation of a predator index, predator control fisheries, and evaluation plan in the Columbia River Basin (Northern Pikeminnow Management Program). 2001 Annual Report, project number 90-077. Contract DE-B179-90-BP07084, Bonneville Power Administration, Portland, Oregon.

Winther, E.C., L.G. Fox, J.D. Hone, and J.A. Memarian. 2002. Implementation of the northern 
pikeminnow sport-reward fishery in the Columbia and Snake Rivers. In Development of a system-wide predator control program: stepwise implementation of a predator index, predator control fisheries, and evaluation plan in the Columbia River Basin (Northern Pikeminnow Management Program). 2002 Annual Report, project number 90-077. Contract DE-B179-90BP07084, Bonneville Power Administration, Portland, Oregon.

Winther, E.C., J.D. Hone, and R.C. Bruce. 2006. Implementation of the northern pikeminnow sport-reward fishery in the Columbia and Snake Rivers. In Development of a system-wide predator control program: stepwise implementation of a predator index, predator control fisheries, and evaluation plan in the Columbia River Basin (Northern Pikeminnow Management Program). 2006 Annual Report, project number 90-077. Contract DE-B179-90BP07084, Bonneville Power Administration, Portland, Oregon. 
Report B

Northern Pikeminnow Sport Reward Payments - 2008

Prepared by

Russell G. Porter

Pacific States Marine Fisheries Commission 205 S.E. Spokane St.

Portland, OR 97202

March, 2009 


\section{INTRODUCTION}

The Northern Pikeminnow Predator Control Program was administered by PSMFC in 2008. The program is a joint effort between the fishery agencies of the states of Washington and Oregon, and the Pacific States Marine Fisheries Commission (PSMFC). Washington ran the sport-reward registration/creel check stations throughout the river and handled all fish checked in to the program. Oregon provided fish tagging services, population studies, food habit and reproductive studies, as well as exploitation rate estimates. PSMFC provided technical administration, and the fiscal and contractual oversight for all segments of the Program and processed all reward vouchers for the sport-reward anglers.

\section{CATCH AND PAYMENTS}

In 2008 a total of 159,806 fish were harvested in the sport-reward fishery. Of this total 167 were tagged fish and 159,639 were untagged. Vouchers for 158,674 of the untagged fish were submitted for payment totaling rewards of $\$ 1,001,693$. Rewards were paid at $\$ 4$ for the first 100 fish caught during the season, $\$ 5$ for fish in the 101-400 range, and $\$ 8$ for all fish caught by an angler above 400 fish. PSMFC maintained an accounting system during the season to determine the appropriate reward amount due each angler for particular fish. A total of 994 anglers who registered were successful in catching one or more fish in 2008. The 2008 season ran from May 5, 2008 through October 12, 2008.

\section{TAGGED FISH PAYMENTS}

A total of 167 tagged fish were caught. Anglers were issued a special tagged fish voucher for all tagged fish brought to the registration station. The tag voucher was then sent in with the tag for verification and payment of the special \$500 tagged fish reward. All 167 tagged vouchers were submitted for payment This resulted in tag reward payments of $\$ 83,500$ in addition to the regular reward payments above.

\section{TOURNAMENT DRAWINGS}

A one month tournament was held this season. Each week all anglers who had turned in a voucher for that week were eligible for a weekly drawing. Five angler names were drawn and each won a prize of $\$ 2,000$. One entry into the weekly drawing was issued for each angler on each day they turned in fish. The tournament drawings took place in August. A total of $\$ 40,000$ was paid out to the twenty anglers drawn for the four week promotion period. 


\section{ACCOUNTING}

Total payments for the season of regular vouchers and tagged fish, totaled $\$ 1,125,193$. All IRS Form 1099 Mis. Statements were sent to the qualifying anglers for tax purposes in the third week of January, 2008. Appropriate reports and copies were provided to the IRS by the end of February, 2008.

A summary of the catch and rewards paid is provided in Table 1. For further information contact Russell Porter, PSMFC, Field Programs Administrator at (503) 595-3100 or email at: russell_porter@psmfc.org. 


\section{SPORT REWARD PAYMENTS SUMMARY}

The following is a summary of the vouchers received and paid as of November 17, 2008

\begin{tabular}{rcc} 
& Fish & $\$$ Paid \\
Fish paid @ tier 1 (\$4.00 each): & 33,686 & $\$ 134,744$ \\
Fish paid @ tier 2 (\$5.00 each): & 43,873 & $\$ 219,365$ \\
Fish paid @ tier 3 (\$8.00 each): & 80,948 & $\$ 647,584$ \\
Tags paid (@ $\$ 500.00$ each): & 167 & $\$ 83,500$ \\
Tournament prizes & 20 & $\$ 40,000$ \\
\cline { 2 - 3 } Total: & $\mathbf{1 5 8 , 6 7 4}$ & $\$ \mathbf{1 , 1 2 5 , 1 9 3}$
\end{tabular}

Anglers@ tier 1779

Anglers @ tier 2110

Anglers with 10 fish or less: $\quad 485$

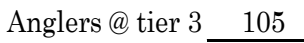

Anglers with 2 fish or less: 202

Number of separate anglers 994

\begin{tabular}{|c|c|c|c|c|c|c|c|}
\hline Top Twenty Anglers * & TIER 1 & TIER 2 & TIER 3 & TAGS & $\begin{array}{c}\text { TOTAL } \\
\text { FISH }\end{array}$ & $\begin{array}{c}\text { WEEKLY } \\
\text { DRAWING }\end{array}$ & BALANCE \\
\hline 1. ZAREMSKIY, NIKOLAY N & 100 & 300 & 6,609 & 6 & 7,015 & $\$ 0$ & $\$ 57,772$ \\
\hline 2. VASILCHUK, DAVID R & 100 & 300 & 4,776 & 9 & 5,185 & $\$ 0$ & $\$ 44,608$ \\
\hline 3. VASILCHUK, IVAN R & 100 & 300 & 3,419 & 6 & 3,825 & $\$ 0$ & $\$ 32,252$ \\
\hline 4. ORLOVSKIY, VIKTOR M & 100 & 300 & 3,292 & 1 & 3,693 & $\$ 0$ & $\$ 28,736$ \\
\hline 5. HISTAND,TIMOTHY L & 100 & 300 & 3,250 & 2 & 3,652 & $\$ 0$ & $\$ 28,900$ \\
\hline 6. WILLIAMS, EDWARD R & 100 & 299 & 2,177 & 1 & 2,577 & $\$ 0$ & $\$ 19,811$ \\
\hline 7. WEBER, STEVEN A & 100 & 300 & 2,019 & 1 & 2,420 & $\$ 0$ & $\$ 18,552$ \\
\hline 8. KEILWITZ,DANIEL D & 100 & 300 & 1,981 & 0 & 2,381 & $\$ 0$ & $\$ 17,748$ \\
\hline 9. RARDIN, HANK J & 100 & 300 & 1,923 & 1 & 2,324 & $\$ 0$ & $\$ 17,784$ \\
\hline PAPST,THOMAS H & 100 & 300 & 1,755 & 3 & 2,158 & $\$ 0$ & $\$ 17,440$ \\
\hline GEIGER, DANIEL J & 100 & 300 & 1,712 & 2 & 2,114 & $\$ 0$ & $\$ 16,596$ \\
\hline JONES, JOHN A & 100 & 298 & 1,628 & 3 & 2,029 & $\$ 0$ & $\$ 16,414$ \\
\hline SMITH, LARRY L & 100 & 300 & 1,601 & 0 & 2,001 & $\$ 0$ & $\$ 14,708$ \\
\hline HUNTER, KENNETH W & 100 & 300 & 1,564 & 1 & 1,965 & $\$ 0$ & $\$ 14,912$ \\
\hline VASILCHUK, OLEG R & 100 & 298 & 1,559 & 4 & 1,961 & $\$ 0$ & $\$ 16,362$ \\
\hline LEVCHENKOV, VASILIY G & 100 & 300 & 1,380 & 0 & 1,780 & $\$ 0$ & $\$ 14,940$ \\
\hline GLASPIE, ROBERT R & 100 & 300 & 1,358 & 0 & 1,758 & $\$ 0$ & $\$ 12,764$ \\
\hline MILLER, EARL D & 100 & 300 & 1,345 & 2 & 1,747 & $\$ 2,000$ & $\$ 15,660$ \\
\hline MILLER, VERLON D & 100 & 300 & 1,311 & 0 & 1,711 & $\$ 0$ & $\$ 12,388$ \\
\hline SWANGER, RICHARD L & 100 & 300 & 1,271 & 0 & 1,671 & $\$ 0$ & $\$ 12,068$ \\
\hline * (by total fish caught) & 2,000 & 5,995 & 45,930 & 42 & 53,967 & $\$ 2,000$ & $\$ 430,415$ \\
\hline
\end{tabular}


Report C

System-wide Predator Control Program: Indexing and Fisheries Evaluation

Prepared by

\author{
Michele Hughes Weaver \\ Howard K. Takata \\ Martyne J. Reesman \\ Erick S. Van Dyke
}

\author{
Oregon Department of Fish and Wildlife \\ Columbia River Coordination Program \\ 17330 S.E. Evelyn Street \\ Clackamas, Oregon 97015 \\ Funded by \\ U. S. Department of Energy \\ Bonneville Power Administration \\ Division of Fish and Wildlife \\ Portland, Oregon 97208-3621 \\ Project No. 1990-077-00 \\ Contract No. 26763
}

March 2009 


\section{SUMMARY}

The Northern Pikeminnow Management Program (NPMP), fisheries aimed at reducing predation on juvenile salmonids by northern pikeminnow Ptychocheilus oregonensis in the Columbia and Snake rivers, was assessed for the $19^{\text {th }}$ year. We report on 1) northern pikeminnow exploitation rates, predation estimates, and tag loss, 2) population parameters of northern pikeminnow, smallmouth bass Micropterus dolomieu, and walleye Sander vitreus from below Bonneville Dam and in Bonneville Reservoir, and 3) possible compensatory responses by these species.

To evaluate exploitation, we tagged and released 1,005 northern pikeminnow $\geq 200 \mathrm{~mm}$ fork length (FL) throughout the lower Columbia and Snake rivers in 2008. Of these, 651 were $\geq 250$ $\mathrm{mm}$ FL. System-wide exploitation of northern pikeminnow $\geq 200 \mathrm{~mm}$ FL by the sport-reward fishery was $14.8 \%$ (95\% confidence bounds $10.5 \%-19.2 \%$ ), which incorporated a tag loss estimate of 5.0\%. Sport-reward exploitation of fish $\geq 250 \mathrm{~mm}$ FL was $19.5 \%(13.2 \%-25.7 \%)$, the highest exploitation rate since program inception. Based on sport-reward exploitation rates; using our current predation reduction model, we estimated that 2008 predation levels were $38 \%$ (range: $21 \%-55 \%$ ) lower than pre-program levels.

We conducted biological indexing in the lower Columbia River as part of our predator community evaluation. Northern pikeminnow abundance indices in Bonneville Reservoir and below Bonneville Dam continued a downward trend and were the lowest observed to date. Although $45 \%$ of northern pikeminnow stomachs were empty, 124 samples contained identifiable fish remains, of which $69 \%$ were identified as juvenile salmonids. Consumption indices were higher in some areas this year and lower in others. The highest consumption index to date was calculated this year in an area below Bonneville dam in the spring and the lowest to date was also this year in the Bonneville Dam tailrace boat restricted zone during summer. Predation indices varied this year by location and season. Relative weights of northern pikeminnow are slightly up in 2008 and year-class analyses show variation from year to year in the percentage of age 3 and 4 fish.

The relative weights for smallmouth bass have fluctuated over the years thus showing no discernable trend. Smallmouth bass proportional stock density and relative stock density below Bonneville Dam and in Bonneville Reservoir are higher than when previously sampled but within the range of all previous years. Consumption and predation indices are lower this year in the spring but higher in the summer than previously. Smallmouth bass stomachs contained identifiable fish remains in 149 samples, of which $26 \%$ were identified as juvenile salmonids. The prey fish most often consumed by smallmouth bass continues to be Cottus spp.

Walleye abundance continues to be low compared to northern pikeminnow and smallmouth bass. Walleye are primarily captured in the tailrace sections and the relative weights and year class analysis show variation, with no discernable trends. Compared to smallmouth bass, walleye stomachs contained a higher proportion of juvenile salmonids, but not as high as northern pikeminnow. 
At this time, there does not appear to be a system-wide predator response to the Northern Pikeminnow Management Program. However, there may be some early signs of compensation by other piscivores to the sustained removal of northern pikeminnow. These indicators are localized to small areas below Bonneville dam and in Bonneville and John Day reservoirs, and may involve density-independent factors not being measured by our investigation. Continued monitoring is necessary to assess impacts associated with the fishery and potential association with localized changes.

\section{INTRODUCTION}

The Columbia and Snake rivers once supported large numbers of anadromous salmonids Oncorhynchus spp. Declines in adult returns have been attributed to many factors, including habitat degradation and overexploitation (Nehlsen et al. 1991; Wismar et al. 1994), hydroelectric and flood control activities during the 1970's (Raymond 1988), and predation (Rieman et al. 1991; Collis et al. 2002). The mean annual loss of juvenile salmonids to predators can be equivalent to mortality associated with dam passage (Rieman et al. 1991), which in the past could approach 30\% at a single dam (Long and Ossiander 1974). The Northern Pikeminnow Management Program (NPMP) is a set of targeted fisheries aimed at reducing predation on juvenile salmonids by northern pikeminnow Ptychocheilus oregonensis in the lower Columbia and Snake rivers (Rieman and Beamesderfer 1990; Beamesderfer et al. 1996). The Oregon Department of Fish and Wildlife (ODFW) established baseline levels of predation and northern pikeminnow population characteristics prior to the implementation of the northern pikeminnow fisheries. Abundance, consumption, and predation were estimated in Columbia River reservoirs in 1990 and 1993, Snake River reservoirs in 1991, and the unimpounded lower Columbia River downstream from Bonneville Dam in 1992 (Ward et al. 1995). We continue to sample northern pikeminnow populations in standardized areas, and to compare results among years when sample sizes are adequate to avoid biasing estimates (Zimmerman and Ward 1999; Zimmerman et al. 2000; Jones et al. 2005). This report describes our activities and findings for 2008, and wherever possible, evaluates changes from previous years.

Our objectives in 2008 were to 1) evaluate northern pikeminnow exploitation, potential predation, and tag loss, 2) define population parameters of northern pikeminnow, smallmouth bass Micropterus dolomieu, and walleye Sander vitreus below Bonneville Dam and in Bonneville reservoir, and 3) look for possible compensatory responses by these species.

\section{METHODS}

Fishery Evaluation, Predation Estimates, and Tag Loss

Field Procedures - The Washington Department of Fish and Wildlife (WDFW) administered the sport-reward fishery from 5 May to 15 October 2008 throughout the lower Columbia and Snake rivers. Participating anglers received payment for northern pikeminnow $\geq 230 \mathrm{~mm}$ (9 inches) total length (TL). This size limit is approximately equivalent to $200 \mathrm{~mm}$ fork length (FL). The payment schedule for 2008 consisted of three tiers (Porter 2009, this report): US\$4 per fish for “Tier 1" anglers ( $<100$ fish caught per angler), \$5 per fish for "Tier 2" anglers (100-400 fish 
caught per angler), and $\$ 8$ per fish for "Tier 3" anglers ( $>400$ fish caught per angler). Rewards for fish with a Floy FT-4 lock-on loop tag continued to be $\$ 500$.

The U.S. Department of Agriculture (USDA) Wildlife Services Division conducted an employee hook and line (dam-angling) fishery at The Dalles and John Day dams from 15 May to 15 August 2008. This was a removal fishery designed to further decrease predation in the immediate tailrace area of the dams. To collect biological data from northern pikeminnow caught in this fishery, we sub-sampled the catch once to twice per week during the fishery.

We tagged and released northern pikeminnow $\geq 200 \mathrm{~mm}$ FL with uniquely numbered Floy FT-4 lock-on loop tags to estimate exploitation rates for the sport-reward and dam-angling fisheries. To evaluate tag retention, we also injected a passive integrated transponder (PIT) tag into the dorsal sinus of all loop-tagged fish. During late winter (4-7 March 2008), we used bottom gillnets and electrofishing boats to collect northern pikeminnow in boat restricted zones (BRZ) near The Dalles, John Day, and McNary dams prior to the start of spill. We used electrofishing boats to collect northern pikeminnow from 3 April to 17 June 2008 in the remaining areas (detailed methods are given in Friesen and Ward 1999). We sampled in the Columbia River from river kilometer (rkm) 76 (near Clatskanie, Oregon) upstream to rkm 639 (Priest Rapids Dam) and in the Snake River from rkm 112 (Little Goose Dam) to rkm 248 (Figure 1). Though we attempted to allocate equal sampling effort in all river kilometers, some deviation was necessary due to sampling logistics and adverse weather conditions.

We completed northern pikeminnow tagging below Bonneville Dam and in Bonneville and The Dalles reservoirs before the start of the sport-reward fishery. Tagging operations ran concurrently with the fishery in John Day, McNary, Little Goose and Lower Granite reservoirs.

Data Analysis - We used mark-and-recapture data to compare exploitation rates of northern pikeminnow $\geq 200 \mathrm{~mm}$ FL, 200-249 $\mathrm{mm}$ FL, and $\geq 250 \mathrm{~mm}$ FL among reservoirs. In areas where tagging was completed prior to the start of the fishery, we used a simple Peterson method (Ricker 1975) to calculate annual exploitation rates. This is given by the equation

where

$$
\mathrm{u}=\mathrm{R} / \mathrm{M} \text {, }
$$

$\mathrm{u}=$ annual exploitation estimate,

$\mathrm{M}=$ the number of fish that are tagged in a season, and

$\mathrm{R}=$ the number of tagged fish that are recaptured in a season.

We calculated $95 \%$ confidence intervals for exploitation estimates using the formula

$$
\left(\mathrm{R} \pm \mathrm{z}^{*} \mathrm{R}^{0.5}\right) / \mathrm{M}
$$




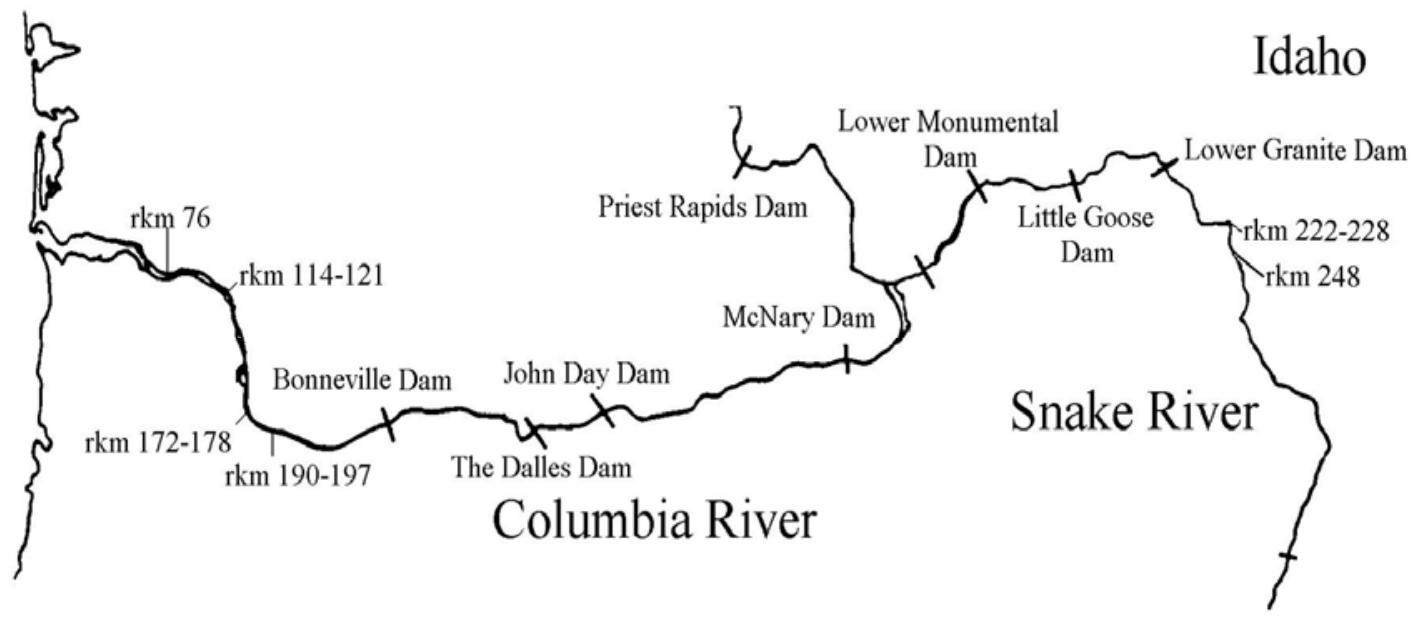

Figure 1. The lower Columbia and Snake rivers. Northern pikeminnow were tagged from river kilometer (rkm) 76 to Priest Rapids Dam in the lower Columbia River and from Little Goose Dam forebay to rkm 248 on the Snake River. Biological indexing was conducted below Bonneville Dam and in Bonneville Reservoir during the spring and summer of 2008.

where

$$
\begin{aligned}
& \mathrm{Z}=\text { the multiplier from the standard normal distribution, } \\
& \mathrm{M}=\text { the number of fish that are tagged in a season, and } \\
& \mathrm{R}=\text { the number of tagged fish that are recaptured in a season (Styer 2003). }
\end{aligned}
$$

We calculated multi-year exploitation rates in 2008 from 2003-2008 PIT tag return data for the area below Bonneville Dam and in Bonneville Reservoir using a variable survival method (Everhart and Youngs 1981) for northern pikeminnow $\geq 200 \mathrm{~mm}$ FL. This is given by the equation

$$
\mathrm{f}_{\mathrm{i}}=\mathrm{R}_{\mathrm{i}} / \mathrm{M}_{\mathrm{i}} * \mathrm{C}_{\mathrm{i}} / \mathrm{T}_{\mathrm{i}}
$$

where

$$
\begin{aligned}
& \mathrm{f}_{\mathrm{i}}=\text { the minimum estimate of exploitation in year } \mathrm{i}, \\
& \mathrm{M}_{\mathrm{i}}=\text { the number of fish that are tagged in year } \mathrm{i}, \\
& \mathrm{R}_{\mathrm{i}}=\text { the total number of recaptures from a particular tagging release, } \\
& \mathrm{C}_{\mathrm{i}}=\text { the total number of fish that are recaptured in any sample year, and } \\
& \mathrm{T}_{\mathrm{i}}=\mathrm{T}_{\mathrm{i}-1}+\mathrm{R}_{\mathrm{i}}-\mathrm{C}_{\mathrm{i}-1} \text { where } \mathrm{T}_{1} \equiv \mathrm{R}_{1} .
\end{aligned}
$$

We used a multiple sample approach to compute exploitation rates in areas where tagging and fishing occurred concurrently (Styer 2003). Weekly estimates of exploitation were calculated by dividing the number of tagged northern pikeminnow recovered by the number of tagged fish at- 
large. We then summed the weekly exploitation rates to yield total exploitation rates for the season (Styer 2003). Appendix Table A-1 shows sampling weeks used in 2008.

We calculated $95 \%$ confidence intervals for exploitation estimates obtained by the multiple sample method by using the formula

$$
\mathrm{u} \pm \mathrm{t}\left(\mathrm{k}^{*} \mathrm{~s}\right)^{0.5}
$$

where

$\mathrm{u}=$ the annual exploitation estimate,

$\mathrm{t}=$ the multiplier from the Student's t-distribution,

$\mathrm{k}=$ the number of weeks in the fishing season, and

$\mathrm{s}=$ the standard deviation of the weekly exploitation estimates (Styer 2003).

We did not calculate exploitation rates for areas where the number of recaptures was less than four (Styer 2003). Exploitation estimates from previous years with fewer than four tags recoveries were excluded from this report. We adjusted exploitation estimates and confidence intervals for tag loss. An annual tag loss estimate was calculated using the formula

$$
\mathrm{L}=[\mathrm{m} /(\mathrm{m}+\mathrm{r})] * 100
$$

where

$$
\begin{aligned}
& \mathrm{L}= \text { tag loss rate, } \\
& \mathrm{m}= \text { the number of northern pikeminnow recaptured with a secondary mark (PIT tag) and } \\
& \text { no Floy FT- } 4 \text { lock-on loop tag, and } \\
& \mathrm{r}= \text { the number of northern pikeminnow recaptured with year } 2008 \text { Floy FT-4 lock-on } \\
& \quad \text { loop tags intact. }
\end{aligned}
$$

We assessed the relationship between annual exploitation of northern pikeminnow in the sport fishery and river flow from 1995 through 2008. River flow was based on the mean of Columbia River stage data measured below Bonneville Dam (site number 14128870; USGS unpublished data) during the season (May-September 1995-2005; May-October 2006-2008). System-wide sport-reward exploitation rates for fish $\geq 250 \mathrm{~mm}$ FL were found to be exponentially related so the data were log transformed. Since the effect of river flow on exploitation rates has weakened since 2004 (Weaver et al. 2008), we also examined other variables (e.g. fishery catch and other indicators of angler success) that may have affected system-wide exploitation rates for northern pikeminnow $\geq 250 \mathrm{~mm}$ FL during 2004-2008. We used simple linear regression of the variables to conduct these analyses.

We used a model described in Friesen and Ward (1999) to estimate predation on juvenile salmonids relative to predation before the implementation of the Northern Pikeminnow Management Program. The model estimates potential predation reduction from preprogram conditions using the parameters 1) population structure before removals by fisheries 2) consumption of juvenile salmonids by northern pikeminnow 3) fish length 4) size-specific exploitation rates and 5) annual mortality. We use a 10-year average age structure (based on 
catch curves) for a pre-exploitation base, and assumed a constant recruitment. The model was updated to include fork length increments with measured growth instead of age increments and estimated growth. We changed age increments to fork length increments by calculating the intervals on measured annual growth from mark and recapture information. The model predicts changes in potential predation that are directly related to removals, providing an estimate of the effect of removal when all other variables are held constant. We estimated the potential relative predation in 2008 based on observed exploitation rates and the eventual potential predation assuming continuing exploitation at mean levels from recent years.

\section{Biological Evaluation}

Field Procedures-We used standardized electrofishing to evaluate changes in northern pikeminnow and smallmouth bass abundance, consumption and predation indices, stock densities, size and age structure, condition, and feeding habits. We also analyzed relative abundance, stock density and age structure, condition, and feeding habits of walleye. Biological data were collected in spring (12-30 May) and summer (23 June-11 July) 2008 in the following areas: downstream of Bonneville Dam (rkm 114-120, rkm 170-179, and rkm 186-194), Bonneville Dam tailrace (rkm 224-232), Bonneville Reservoir (forebay rkm 233-238, midreservoir rkm 272-283), and The Dalles Dam tailrace (rkm 299-306) (Figure 1). Sampling methods and gear specifications have been previously described (Ward et al. 1995; Zimmerman and Ward 1999).

We recorded biological data from all northern pikeminnow, smallmouth bass, and walleye collected. We took scale samples in groups of 25 fish per $25 \mathrm{~mm}$ FL size increment from northern pikeminnow, smallmouth bass, and walleye in each reservoir we sampled. In addition, walleye scales collected during tagging operations in 2008 were used to supplement those collected during the indexing season. From fish $\geq 200 \mathrm{~mm}$ FL we measured total body weight $(\mathrm{g})$, collected and preserved digestive tracts from northern pikeminnow, and recovered the digestive tract contents from smallmouth bass and walleye using methods described by Ward et al. (1995). We noted sex (male, female, or undetermined) and maturity (undetermined, immature, developing, ripe, or spent) while collecting northern pikeminnow digestive tracts.

Laboratory Procedures.-We examined digestive tract contents of northern pikeminnow, smallmouth bass, and walleye to measure relative consumption rates of juvenile salmonids. Details of laboratory methods are given in Ward et al. (1995). Standard methods of determining ages from scales were used (DeVries and Frie 1996).

Data Analysis. - We used catch per unit effort (CPUE) and reservoir or area-specific surface areas to calculate northern pikeminnow abundance indices (Ward et al. 1995). We compared abundance indices of northern pikeminnow in 2008 with those from previous years. We used transformed catch $\left(\log _{10}(\mathrm{catch}+1)\right)$ as an index of smallmouth bass and walleye relative densities.

We used the following formulas to calculate consumption indices for northern pikeminnow (Ward et al. 1995) and smallmouth bass (Ward and Zimmerman 1999) 


$$
\mathrm{CI}_{\mathrm{NPM}}=0.0209 \cdot \mathrm{T}^{1.60} \cdot \mathrm{W}^{0.27} \cdot\left(\mathrm{S} \cdot \mathrm{GW}^{-0.61}\right)
$$

and

$$
\mathrm{CI}_{\mathrm{SMB}}=0.0407 \cdot \mathrm{e}^{(0.15)(\mathrm{T})} \cdot \mathrm{W}^{0.23} \cdot\left(\mathrm{S} \cdot \mathrm{GW}^{-0.29}\right),
$$

where

$$
\begin{array}{ll}
\mathrm{CI}_{\mathrm{NPM}} & =\text { consumption index for northern pikeminnow, } \\
\mathrm{CI}_{\mathrm{SMB}} & =\text { consumption index for smallmouth bass, } \\
\mathrm{T} & =\text { water temperature }\left({ }^{\circ} \mathrm{C}\right) \\
\mathrm{W} & =\text { mean predator weight }(\mathrm{g}) \\
\mathrm{S} & =\text { mean number of salmonids per predator, and } \\
\mathrm{GW} & =\text { mean gut weight }(\mathrm{g}) \text { per predator. }
\end{array}
$$

The consumption index is not a direct estimate of the number of juvenile salmonids eaten per day by an average predator; however, it is linearly related to the consumption rate of northern pikeminnow (Ward et al. 1995) and smallmouth bass (Ward and Zimmerman 1999). We compared spring and summer consumption indices for 2008 to those from previous years.

We used the product of abundance and consumption indices to generate an index of predation for northern pikeminnow during spring and summer periods. The index was used to compare relative predation among years that data were collected. The daily juvenile salmonid passage indices at Bonneville Dam were plotted to compare timing of index sampling with concentrations of juvenile salmonids. We started calculating a predation index for smallmouth bass in 2004 as a response to reports of increased abundance in some areas. Ward and Zimmerman (1999) observed that smallmouth bass densities varied seasonally in the Columbia and Snake rivers; we therefore calculated predation indices using CPUE and reservoir or areaspecific surface area as the season-specific relative abundance index. We multiplied the abundance index by its corresponding consumption index to obtain a season-specific predation index.

To evaluate age structure, we examined the change in frequency of age 3-5 northern pikeminnow and age 4-5 smallmouth bass and age 5-6 walleye from 2008 to previous years. Because the relative abundances of northern pikeminnow year classes in electrofishing catches were biased by exploitation rates that varied among years (Friesen and Ward 1999), we limited our comparisons to abundance of northern pikeminnow large enough to be effectively sampled and small enough to be excluded from the Northern Pikeminnow Management Program (ages 3-5). We constructed smallmouth bass electrofishing catch curves (ODFW, unpublished data) and concluded that younger smallmouth bass (ages 1-3) were not sampled in proportion to their abundance. We therefore limited our comparisons to age 4-5 smallmouth bass. We constructed similar catch curves for walleye (ODFW, unpublished data) and found that age 1-4 fish were underrepresented in the catch, so we limited our analysis to age 5-6 walleye. 
Northern pikeminnow exploitation rates are greater for larger fish than for smaller ones (Zimmerman et al. 1995); therefore, sustained fisheries should decrease the abundance of large fish relative to the abundance of smaller fish. We used proportional stock density (Anderson 1980) to compare the size structure of northern pikeminnow, smallmouth bass, and walleye populations among years. Proportional stock density was calculated using the formula

$$
\mathrm{PSD}=100 \cdot\left(\mathrm{FQ}_{\mathrm{i}} / \mathrm{FS}_{\mathrm{i}}\right),
$$

where

$$
\begin{array}{ll}
\mathrm{PSD} & =\text { proportional stock density } \\
\mathrm{FQ}_{\mathrm{i}} & =\text { number of fish } \geq \text { quality length, and } \\
\mathrm{FS}_{\mathrm{i}} & =\text { number of fish } \geq \text { stock length. }
\end{array}
$$

In addition to calculating proportional stock densities for all three species, we calculated relative stock density to examine smallmouth bass and walleye populations. Relative stock density (Gabelhouse 1984) was calculated using the formula

$$
\mathrm{RSD}-\mathrm{P}=100 \cdot\left(\mathrm{FP}_{\mathrm{i}} / \mathrm{FS}_{\mathrm{i}}\right) \text {, }
$$

where

$$
\begin{aligned}
& \text { RSD-P }=\text { relative stock density of preferred size fish }, \\
& F_{i} \quad=\text { number of fish } \geq \text { preferred length, and } \\
& \mathrm{FS}_{\mathrm{i}} \quad=\text { number of fish } \geq \text { stock length. }
\end{aligned}
$$

Stock and quality minimum length categories used for northern pikeminnow were 250 and 380 mm FL, respectively (Beamesderfer and Rieman 1988; Parker et al. 1995). Stock, quality and preferred minimum length categories for smallmouth bass were $180 \mathrm{~mm}, 280 \mathrm{~mm}$, and $350 \mathrm{~mm}$ TL, respectively. For walleye, stock, quality, and preferred minimum length categories were 250 $\mathrm{mm}, 380 \mathrm{~mm}$, and $510 \mathrm{~mm}$ TL, respectively (Willis et al. 1985). We had to convert fork length to total length for smallmouth bass and walleye to conform to the established standards for each species. The conversion for smallmouth was $\mathrm{TL}_{\mathrm{SMB}}=\mathrm{FL}_{\mathrm{SMB}} \cdot 1.040$, and for Walleye the conversion used was $\mathrm{TL}_{\mathrm{WAL}}=\mathrm{FL}_{\mathrm{WAL}} \cdot 1.060$.

Changes in body condition may indicate a response to sustained exploitation. We used relative weight ( $W_{r}$; Anderson and Neumann 1996) to compare the condition of northern pikeminnow, smallmouth bass, and walleye in 2008 with previous years. We used the length-specific standard weight; predicted by a weight-length regression $\left(\log _{10} W_{s}=a^{\prime}+b \cdot \log _{10}(L)\right)$ for northern pikeminnow (Parker et al. 1995), smallmouth bass (Kolander et al. 1993), and walleye (Murphy et al. 1990) to calculate relative weight $\left(W_{r}=100 \cdot\left(W / W_{s}\right)\right)$. We calculated median $W_{r}$ for male and female northern pikeminnow and all smallmouth bass and walleye, which were not sexed. To compare $W_{r}$ among years, we calculated the $95 \%$ confidence intervals and concluded the there was a significant difference where the intervals did not overlap. 


\section{RESULTS}

Fishery Evaluation, Predation Estimates, and Tag Loss

We tagged and released 1,005 northern pikeminnow $\geq 200 \mathrm{~mm}$ FL throughout the lower Columbia and Snake rivers in 2008; 651 were $\geq 250 \mathrm{~mm}$ FL (Table 1). In 2008, removal fisheries harvested 162,008 northern pikeminnow $\geq 200 \mathrm{~mm} ; 158,191$ in the sport-reward fishery (Winther et al. 2009, this report) and 3,817 in the dam-angling fishery (USDA 2009, this report). A total of 116 tagged northern pikeminnow were recaptured in the sport-reward fishery. Fish tagged and recaptured in 2008 were at-large from 4 to 180 days (average of 71 days), and $90 \%$ of the recaptures were $\geq 250 \mathrm{~mm}$ FL (Table 1). In the sport-reward fishery, $64 \%$ of the harvest consisted of northern pikeminnow $\geq 250 \mathrm{~mm} \mathrm{FL}$, and the median fork length was $274 \mathrm{~mm}$ (J. Hone, WDFW, personal communication). Six northern pikeminnow with 2008 PIT tags and missing Floy FT-4 lock-on loop tags were recaptured in the fishery, yielding a tag loss estimate of $4.9 \%$; we adjusted exploitation rates accordingly.

Table 1. Number of northern pikeminnow tagged and recaptured in the sport- reward fishery during 2008.

\begin{tabular}{|c|c|c|c|c|c|c|}
\hline \multirow[b]{2}{*}{ Area or reservoir } & \multicolumn{2}{|c|}{$200-249 \mathrm{~mm} \mathrm{FL}$} & \multicolumn{2}{|c|}{$\geqq 250 \mathrm{~mm} \mathrm{FL}$} & \multicolumn{2}{|c|}{$\geqq 200 \mathrm{~mm} \mathrm{FL}$} \\
\hline & Tagged & Recaptured & Tagged & Recaptured & Tagged & Recaptured \\
\hline Below Bonneville Dam & 23 & 1 & 265 & 56 & $290^{\mathrm{b}}$ & 57 \\
\hline Bonneville & 18 & 1 & 80 & 8 & 98 & 9 \\
\hline The Dalles & 10 & 1 & 28 & 4 & 38 & 5 \\
\hline John Day & 28 & 0 & 16 & 0 & 44 & 0 \\
\hline McNary & 55 & 2 & 185 & 25 & $241^{\mathrm{b}}$ & 27 \\
\hline Little Goose & 133 & 6 & 30 & 5 & 163 & 11 \\
\hline Lower Granite & 84 & 1 & 47 & 4 & 131 & 5 \\
\hline All areas & 351 & 12 & 651 & $104^{\mathrm{a}}$ & $1,005^{\mathrm{b}}$ & $116^{\mathrm{a}}$ \\
\hline
\end{tabular}

a) Includes fish recaptured in a different area or reservoir than originally tagged and not included in area or reservoir-specific exploitation rate calculations.

b) Includes tagged fish of unknown length (not included in $200-249 \mathrm{~mm}$ or $\geq 250 \mathrm{~mm}$ groups).

System-wide exploitation of northern pikeminnow $\geq 200 \mathrm{~mm}$ FL by the sport-reward fishery was 14.8\% (95\% confidence bounds 10.5\%-19.2\%; Appendix Table B-1). Reservoir/area-specific exploitation rates ranged from $4.1 \%$ in Lower Granite Reservoir to $20.6 \%$ in the area below Bonneville Dam. We did not calculate an exploitation rate for John Day Reservoir because no tagged fish were recovered there in 2008 (Appendix Table B-1). We calculated multi-year exploitation estimates of $21.4 \%$ below Bonneville Dam and $10.2 \%$ in Bonneville Reservoir using PIT tag data from 2003-2008; these were slightly higher than the single year estimates for these areas.

The system-wide exploitation rate of northern pikeminnow 200-249 mm FL was 5.7\% for the sport-reward fishery (95\% confidence bounds $1.2 \%-10.2 \%$; Appendix Table B-1). The only 
area that had enough recaptures of fish in this size class to allow for estimation of a reservoirspecific exploitation rate was Little Goose Reservoir where exploitation was 4.8\%.

For northern pikeminnow $\geq 250 \mathrm{~mm}$ FL, system-wide exploitation was $19.5 \%$ (95\% confidence bounds 13.2\%-25.7\%; Appendix Table B-1). Exploitation rates ranged from 9.2\% in Lower Granite Reservoir to $22.2 \%$ in the area below Bonneville Dam (Figure 2). Weekly system-wide exploitation estimates for northern pikeminnow $\geq 200 \mathrm{~mm}$ FL caught in the sport-reward fishery are given in Appendix Table B-2.

In 2008, we again found a significant relationship between the system-wide sport-reward exploitation rate for northern pikeminnow $\geq 250 \mathrm{~mm}$ FL and the mean Columbia River gage height below Bonneville Dam during the sport-reward season $\left(r^{2}=0.33 ; P<0.05\right.$; Figure 3$)$. However, the strength of this relationship continued to decline from previous years. We also found an inverse relationship between the total catch for the top 20 anglers in the program and exploitation rates of northern pikeminnow $\geq 250 \mathrm{~mm}$ FL during $2004-2008\left(r^{2}=0.78 ; P<0.05\right.$; Figure 4). However, there was no association between the proportion of the total sport-reward catch attributed to the top 20 anglers and exploitation rates during the same time frame $\left(r^{2}=\right.$ $0.00 ; P=0.80)$.

We sampled 282 northern pikeminnow caught in the dam-angling fishery, with $77 \%$ of the samples coming from The Dalles Dam. Median fork length of northern pikeminnow caught by dam anglers was $352 \mathrm{~mm}$. No tagged northern pikeminnow were recovered at the dams; therefore, an exploitation rate could not be calculated for this fishery.

Modeling results indicated potential reduction in predation by northern pikeminnow on juvenile salmonids in 2008 ranged from $21 \%$ to $55 \%$ of pre-program levels, with a median estimate of 38\% (Figure 5). Projections through 2012 indicated continued harvest at average 6-year exploitation levels would result in minimal additional reductions in predation. 

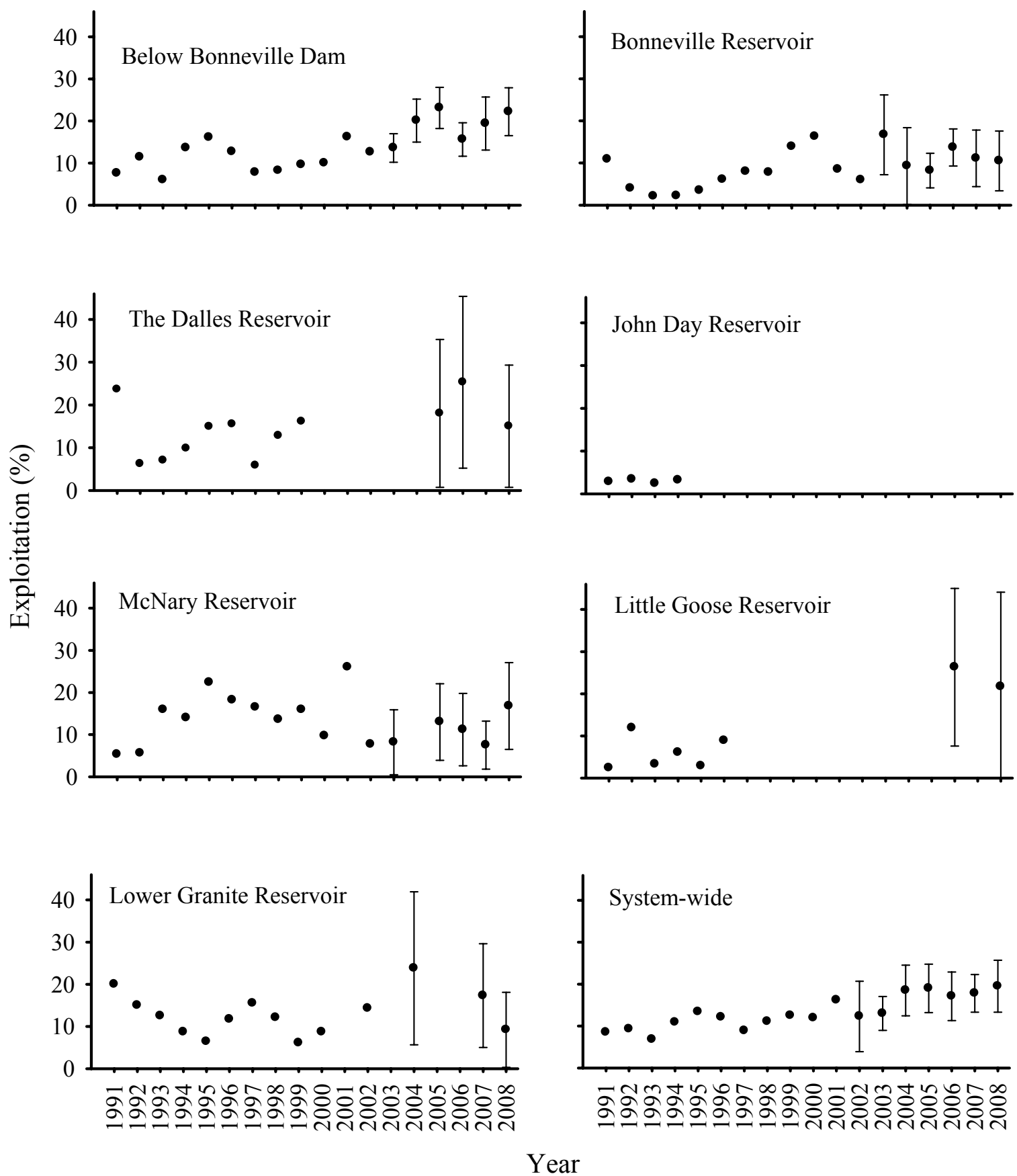

Figure 2. Exploitation rates of northern pikeminnow $\geq 250 \mathrm{~mm}$ fork length in each reservoir or area, 1991-2008. Exploitation rates were not calculated where the number of recaptured tags was low $(n<4)$. Exploitation rates for 2000-2002 were not adjusted for tag loss. Error bars denote the $95 \%$ confidence interval. 


\section{Biological Evaluation}

Predator sampling in 2008 occurred during spring and summer while juvenile salmonids were actively passing through Bonneville Dam (Figure 6). With the exception of the tailrace BRZ below Bonneville Dam, catch per unit effort was generally $<2$ fish per 15-minute electrofishing run during each season for all species (Table 2). Catch per unit effort below Bonneville Dam and in Bonneville Reservoir in 2008 showed a similar pattern seen in other years (Appendix Table C-1). The abundance index for northern pikeminnow ranged from 1.1 to 13.2 below Bonneville Dam, and from 0.2 to 0.4 in Bonneville Reservoir in 2008 (Appendix Table C-2). While the abundance indices below Bonneville Dam fluctuate slightly, Bonneville reservoir continues to decline and is at the lowest since the program began.

Spring and summer smallmouth bass mean relative densities were higher in 2008 than the previous 5 sampling periods, both below Bonneville Dam and in Bonneville Reservoir (Appendix Table C-3; Appendix Table C-4). Densities were highest in the tailrace sections and lowest in the mid reservoir areas.

Relative densities for walleye were calculated below Bonneville Dam and in Bonneville Reservoir for the first time in 2008 (Appendix Table C-5; Appendix Table C-6). Since sampling began in the early 1990's both spring and summer walleye densities have been low. The few walleye captured were primarily from the tailrace sections.

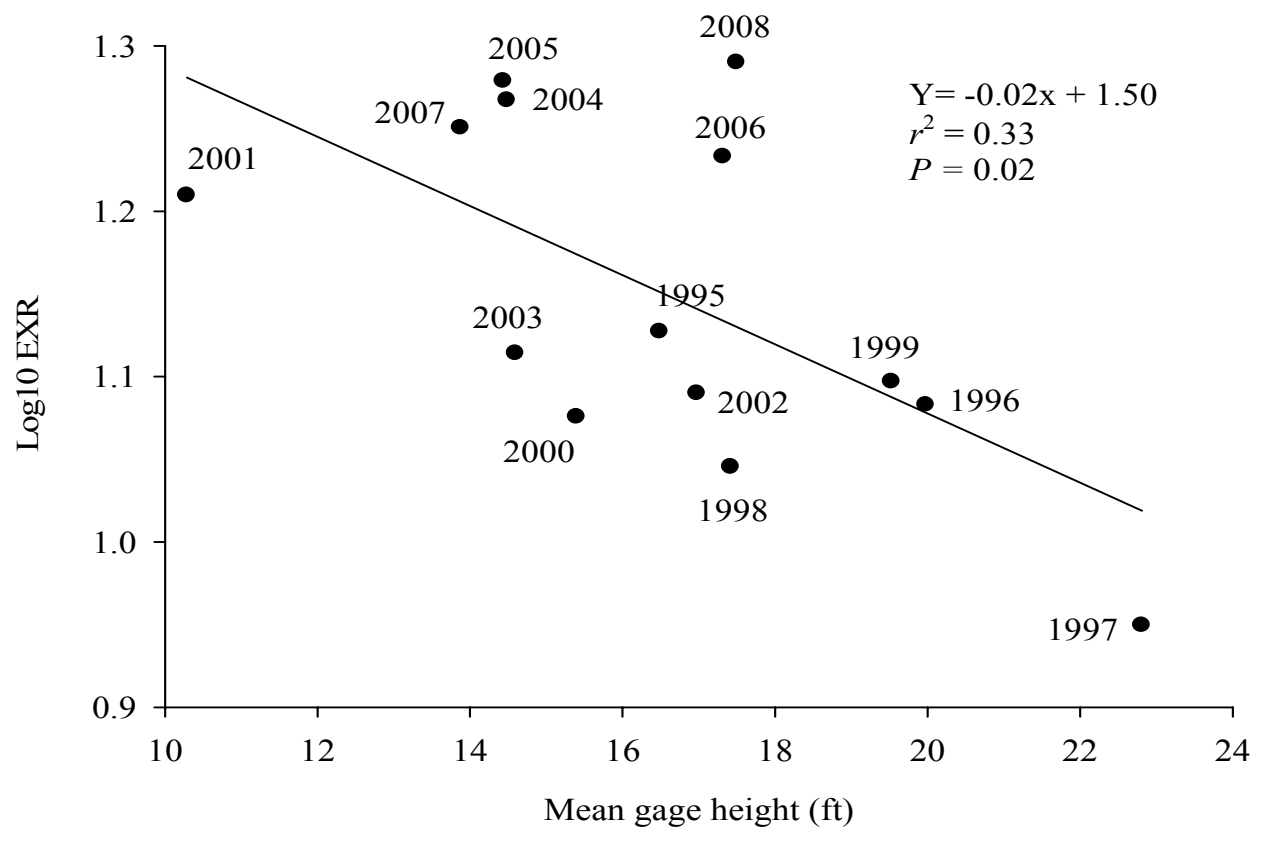

Figure 3. Relationship between system-wide sport-reward exploitation rate ( $\left.\log _{10} \mathrm{EXR}\right)$ of northern pikeminnow $\geq 250 \mathrm{~mm}$ FL and mean Columbia River gage height (ft) below Bonneville Dam during the sport-reward season (May-September 1995-2005; May-October 2006-2008). 


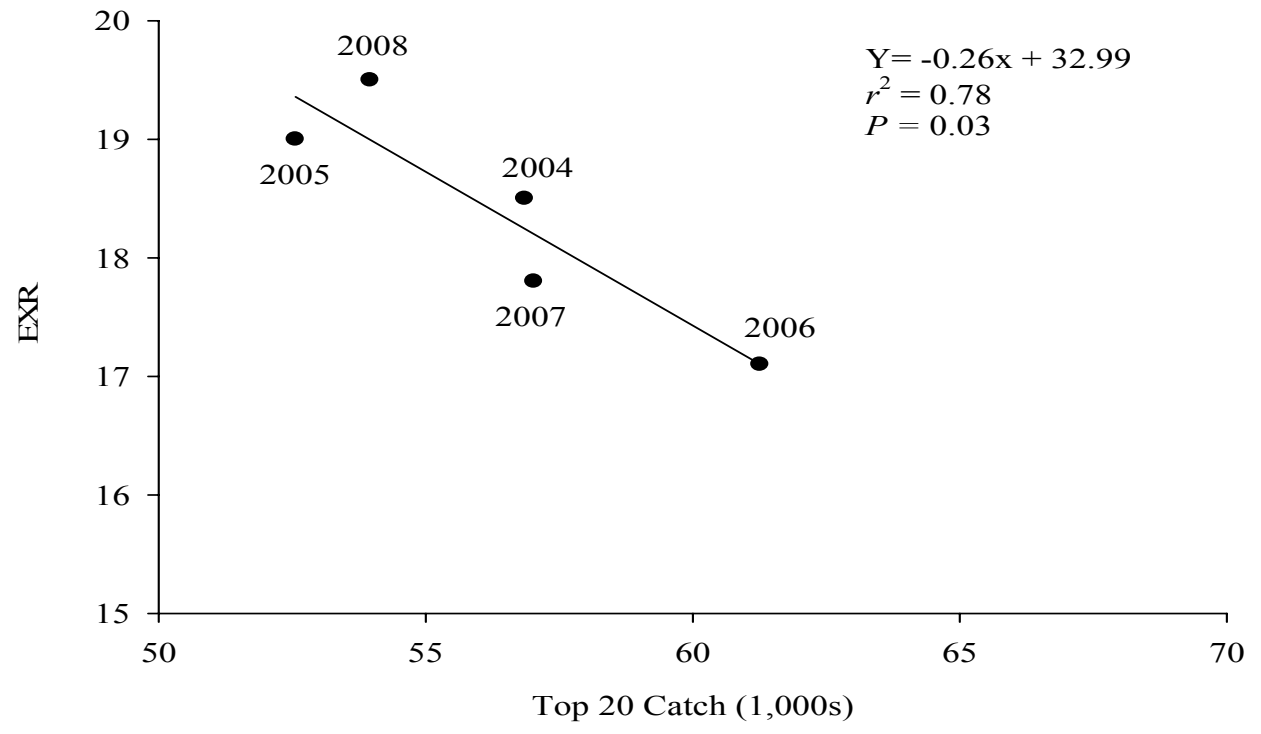

Figure 4. Relationship between system-wide sport-reward exploitation rate of northern pikeminnow $\geq 250 \mathrm{~mm}$ FL and annual catch of Top 20 Northern Pikeminnow Management Program anglers during 2004-2008.

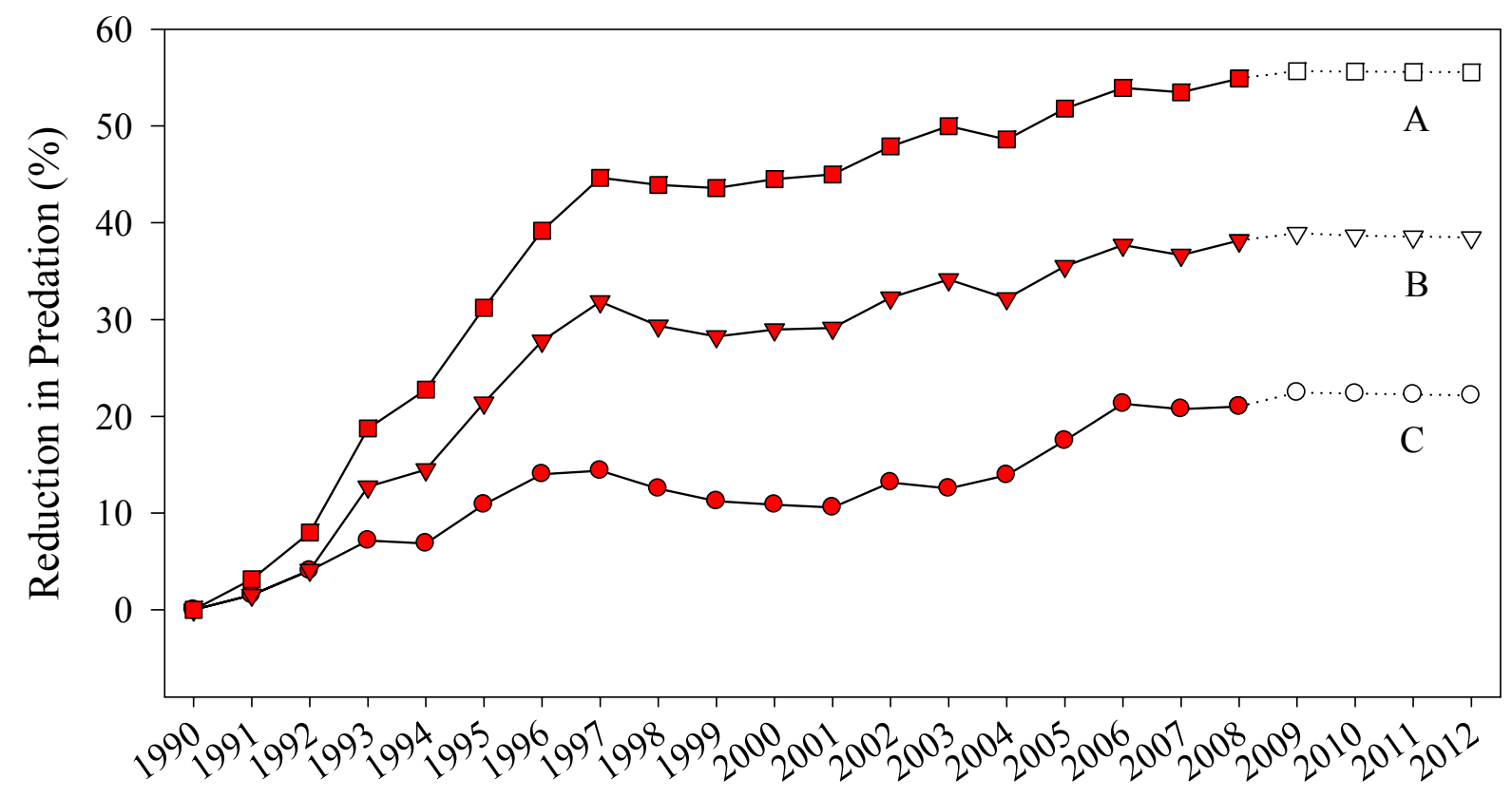

Figure 5. Maximum (A), median (B), and minimum (C) estimates of predation reduction by northern pikeminnow on juvenile salmonids relative to predation prior to implementation of the Northern Pikeminnow Management Program. Estimates of predicted predation after 2008 are based on 6-year average values. 


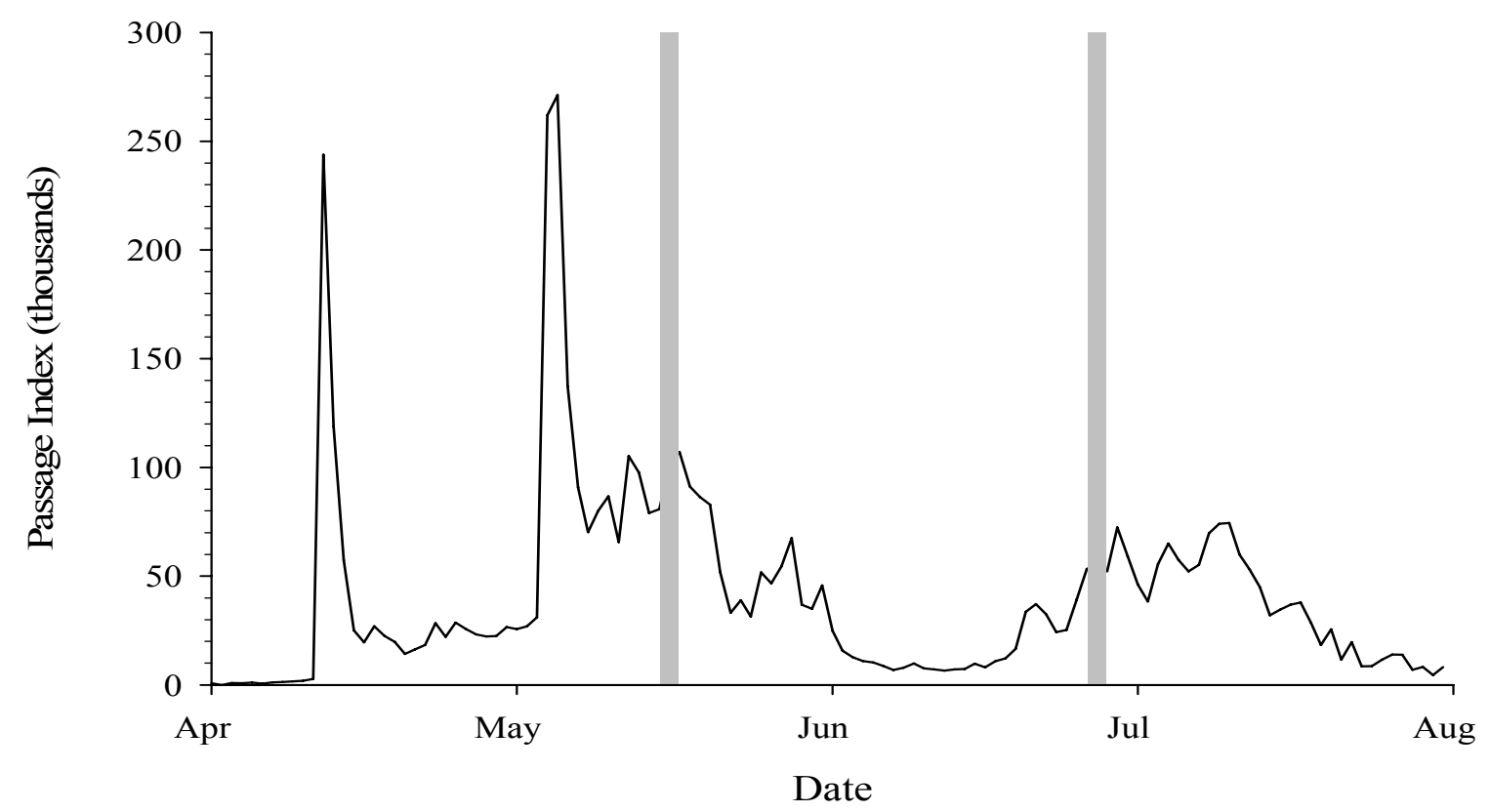

Figure 6. Periods of index sampling (shaded bars) and a smolt index of juvenile salmonids (all species) passing though Bonneville Dam 1 April- 31 July 2008 (Columbia River Data Access in Real Time (DART), unpublished metadata). Shaded areas indicate dates of sampling in the vicinity of the dam. The passage index is estimated fish per volume of water, and is adjusted for river flow (FPC 2005).

Table 2. Spring and summer catch per 15-minute electrofishing run (CPUE) of northern pikeminnow $\geq 250 \mathrm{~mm}$ FL, smallmouth bass $\geq 200 \mathrm{~mm} \mathrm{FL}$, and walleye $\geq 200 \mathrm{~mm}$ FL that were captured during biological indexing in the lower Columbia River in 2008.

\begin{tabular}{|c|c|c|c|c|c|c|}
\hline \multirow[b]{2}{*}{ Area } & \multicolumn{2}{|c|}{ Northern pikeminnow } & \multicolumn{2}{|c|}{ Smallmouth bass } & \multicolumn{2}{|c|}{ Walleye } \\
\hline & Spring & Summer & Spring & Summer & Spring & Summer \\
\hline \multicolumn{7}{|c|}{ Below Bonneville Dam } \\
\hline rkm 114-121 & 1.3 & 0.4 & 0.0 & $<0.1$ & 0.0 & 0.0 \\
\hline rkm 172-178 & 0.8 & 0.4 & 0.2 & 0.7 & 0.0 & $<0.1$ \\
\hline rkm 190-197 & 0.4 & 0.3 & 0.4 & 0.5 & 0.0 & 0.0 \\
\hline Tailrace & 1.3 & 1.5 & 0.7 & 0.5 & $<0.1$ & 0.1 \\
\hline Tailrace BRZ & 9.8 & 15.2 & 3.4 & 1.5 & 0.1 & 0.0 \\
\hline \multicolumn{7}{|c|}{ Bonneville Reservoir } \\
\hline Forebay & 0.3 & 0.1 & 1.6 & 1.4 & 0.0 & 0.0 \\
\hline Mid-reservoir & 0.1 & $<0.1$ & 0.5 & 1.5 & $<0.1$ & $<0.1$ \\
\hline Tailrace & 0.4 & 0.1 & 1.8 & 2.1 & 0.1 & 0.0 \\
\hline
\end{tabular}

We examined 397 northern pikeminnow digestive tracts, 55\% contained food (e.g. crayfish, insects, and fish). Of the digestive tracts that had food contents, $22 \%$ contained salmonids (Appendix Table C-7). The species composition of identifiable fish remains in northern 
pikeminnow digestive tracts varied between areas (Appendix Table C-8). In Bonneville Reservoir, all identifiable fish remains were salmonids while below Bonneville Dam $65 \%$ of the identifiable fish remains were comprised of salmonids

We examined 727 smallmouth bass stomach samples of which $89 \%$ contained food. Of the samples that had food contents, 6\% contained salmonids (Appendix Table C-7). Smallmouth bass consumed salmonids in all areas and seasons (Appendix Table C-7). The species composition of identifiable fish remains in stomach samples was similar among areas and periods (Appendix Table C-8).

We examined 12 walleye stomach samples of which 10 fish contained food. Of the samples that had food content, $42 \%$ contained salmonids (Appendix Table C-7). Below Bonneville Dam and in Bonneville Reservoir identifiable fish remains in walleye varied slightly. Peamouth Mylocheilus caurinus and salmonids were identified most often in both areas (Appendix Table C-8).

Spring 2008 consumption index values for northern pikeminnow below Bonneville Dam and in Bonneville Reservoir were higher in some areas and lower in others (Appendix Table C-9). In rkm 114-121, the Consumption index value matched the highest measured to date. The consumption index values in the other four areas below Bonneville Dam were within the range report in previous years of the study. In Bonneville Reservoir, the spring consumption index value was greater in the forebay than any other year measured to date (Appendix Table C-9). Summer 2008 consumption index values for areas below Bonneville Dam were on the higher end of the range reported for earlier years in rkm 114-121 and rkm 172-178 while values were at the lower end of the range observed in earlier years in rkm 190-197, the tailrace, and the tailrace BRZ (Appendix Table C-10). In the Bonneville Reservoir locations, too few northern pikeminnow $(n \leq 5)$ were collected to calculate summer consumption indices in 2008.

Spring consumption index values for smallmouth bass in 2008 were the same or lower than 2005 and most other previous years below Bonneville Dam and in Bonneville Reservoir (Appendix Table C-11). Summer consumption below Bonneville Dam however was the same or higher in 2008 than in 2005 and most other previous years (Appendix Table C-12). Spring consumption for rkm 114-121 and 172-178 was not calculated due to insufficient sample size $(n \leq 5)$.

Northern pikeminnow predation indices varied by location and season. The highest predation indices in spring were in rkm 114-121 below Bonneville Dam (Appendix Table C-13). Spring predation below Bonneville Dam for rkm 190-197 was lower than all previous years. Summer predation indices were greatest in rkm 114-121(Appendix Table C-14). We were unable to calculate summer predation indices in Bonneville Reservoir due to insufficient sample sizes $(n \leq$ $5)$.

Smallmouth bass predation indices were calculated for the first time in 2004 and continued in 2005 and 2008 using season-specific CPUE data (Appendix Table C-15). Smallmouth bass predation index values did not show any consistent direction of trend in either season or among years. Smallmouth bass predation below Bonneville Dam had a higher index value than northern pikeminnow for rkm 190-197 during both spring and summer, but smallmouth bass had a lower 
value than northern pikeminnow in all other areas and seasons that the comparison could be made (Appendix Table C-16).

Northern pikeminnow year-class analysis downstream of Bonneville Dam varies from year to year in the percentage of age 3 and 4 fish that are represented in our samples (Figure 7). The percentage of age 5 northern pikeminnow has been relatively stable since 1993, accounting for $15-17 \%$ of the total. In Bonneville Reservoir, year class strength appears to be more variable than below Bonneville Dam with oscillations in the percentage of age 3 and 5 fish.

Previous, year-class analysis of smallmouth bass below Bonneville Dam indicated the proportion of the population composed of age 4 fish was growing. This trend did not continue in 2008 (Figure 8). Age-4 smallmouth bass continue to predominate within the age 4-5 group both below Bonneville Dam and in Bonneville Reservoir. In Bonneville Reservoir year class strength appears to vary from year to year, although the percentages of age 5 fish have been higher in recent years then there were prior to 1996.

Walleye year-class analysis is problematic due to low sample sizes. Age 5 walleye predominated within the age 5-6 group below Bonneville Dam and in Bonneville Reservoir (Figure 9). There is a slightly higher percentage of age 5 fish Below Bonneville Dam compared to the earlier years of the program.

The northern pikeminnow proportional stock density value for below Bonneville Dam was the highest value calculated to date (Table 3). In Bonneville Reservoir the proportional stock density value for northern pikeminnow was the second highest value observed since the program began.

Smallmouth bass proportional stock density in 2008 for below Bonneville Dam was lower than most other years (Table 3). Smallmouth bass relative stock density in 2008 below Bonneville Dam was slightly higher than 2005 but was at the lower end of the range of values reported for all other years. In Bonneville Reservoir, smallmouth bass proportional stock density and relative stock density was within the range of all previous years.

We were unable to calculate a walleye proportional stock density or relative stock density in 2008 (Table 3) due to inadequate sample sizes ( $n \leq 20$ for stock size fish). Below Bonneville Dam in 1994 has been the only year that we have collected an adequate sample size to calculate proportional stock density and relative stock density since the program began. 


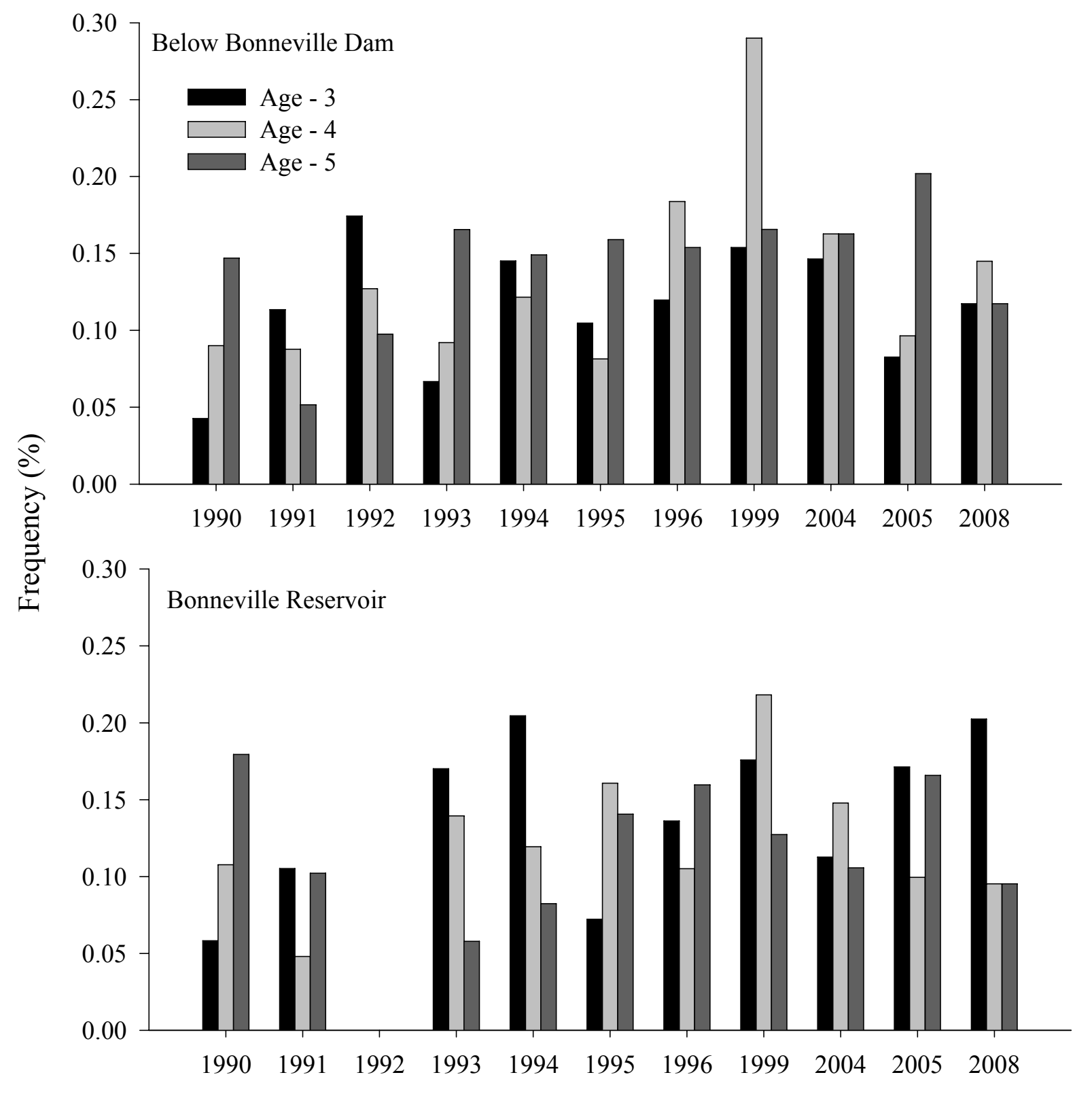

Figure 7. Percent composition of age 3-5 northern pikeminnow, relative to the total sample, below Bonneville Dam and in Bonneville Reservoir 1990-2008. 


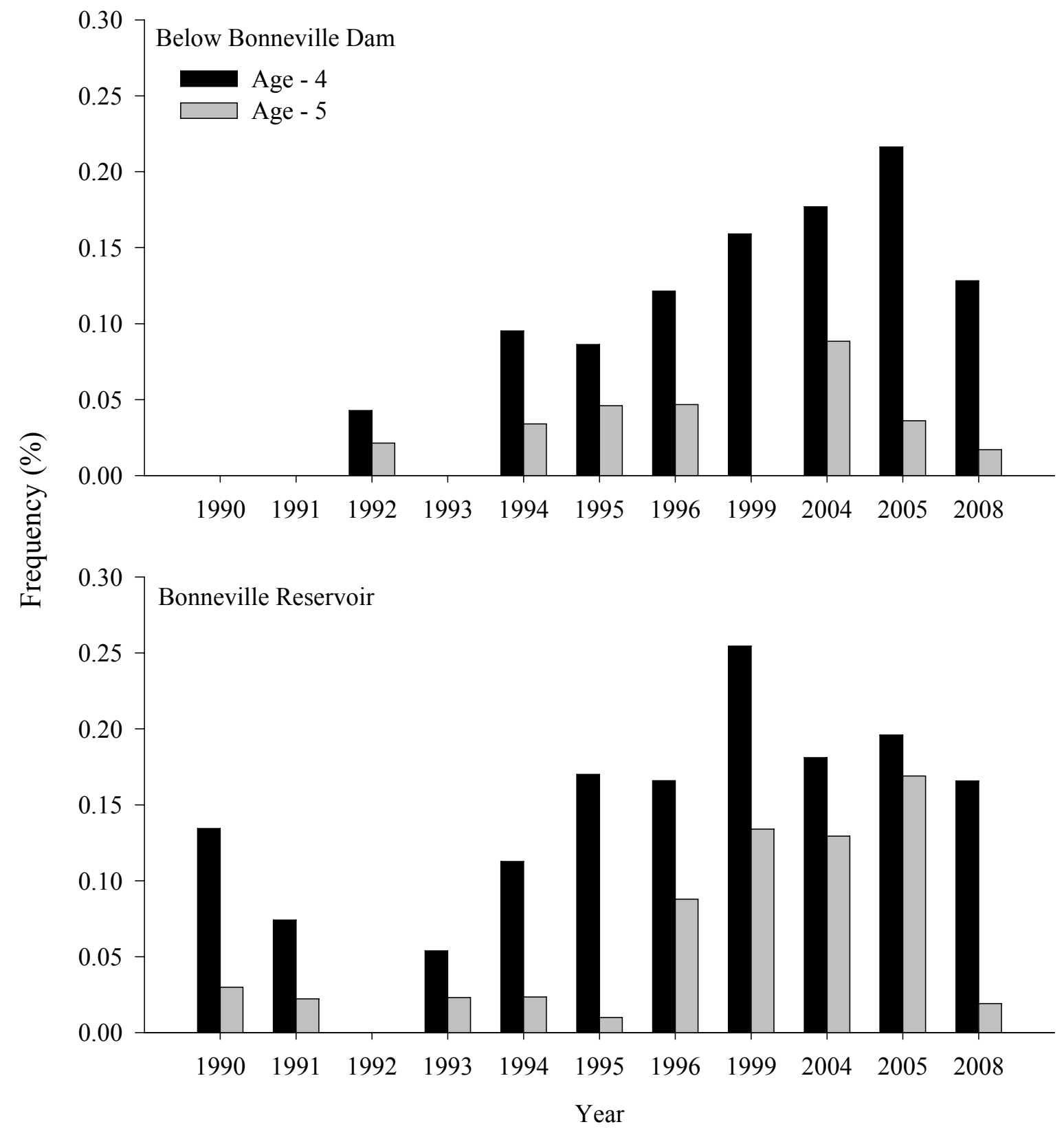

Figure 8. Percent composition of age 4-5 smallmouth bass, relative to the total sample, below Bonneville Dam and in Bonneville Reservoir 1990-2008. 


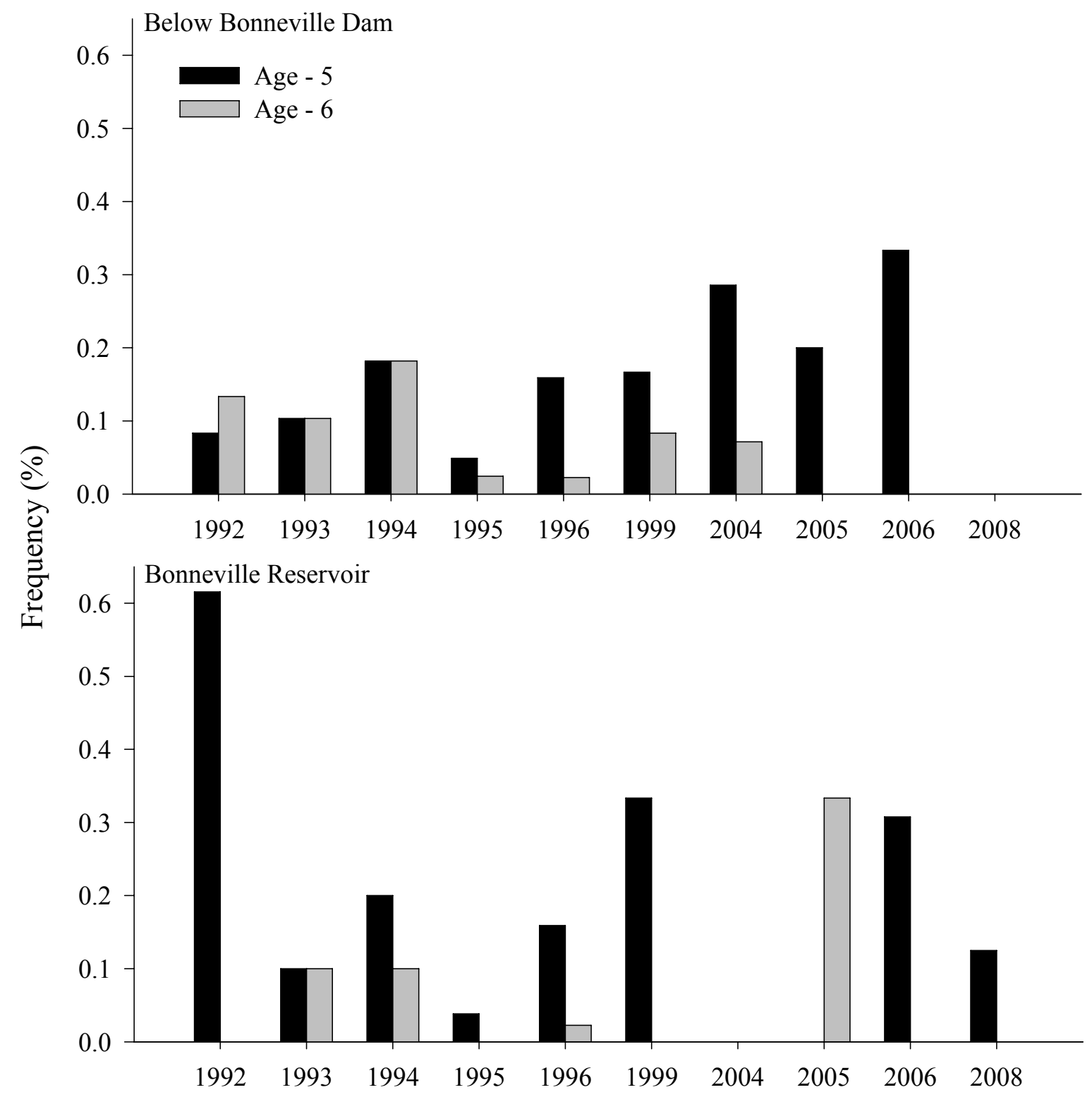

Figure 9. Percent composition of age 5-6 walleye, relative to the total sample, below Bonneville Dam and in Bonneville Reservoir 1992-2008. 
Table 3. The number $(N)$ of stock sized northern pikeminnow, smallmouth bass, and walleye with proportional stock density (PSD), and relative stock density (RSD-P) in the lower Columbia River (1990, 1992-1996, 1999, 2004, 2005, and 2008). $a=$ Number (stock sized fish) $\leq 20$, no stock density index calculated; - = not sampled.

\section{Location,}

Species,

Parameter

1990

1991

1992

1993

1994

1995

1996

1999

2004

2005

2008

\section{Below Bonneville Dam}

Northern pikeminnow

$\begin{array}{lrrrrrrrrrrr}N & 172 & 411 & 710 & 291 & 409 & 206 & 245 & 226 & 356 & 287 & 344 \\ \text { PSD } & 53 & 52 & 29 & 51 & 33 & 41 & 33 & 39 & 35 & 49 & 65\end{array}$

Smallmouth bass

$\begin{array}{lrrrrrrrrrrr}N & 8 & 16 & 153 & 30 & 141 & 181 & 83 & 54 & 172 & 238 & 314 \\ \text { PSD } & a & a & 22 & 63 & 31 & 41 & 30 & 46 & 30 & 19 & 25 \\ \text { RSD-P } & a & a & 7 & 13 & 12 & 15 & 6 & 13 & 6 & 2 & 4\end{array}$

Walleye

$\begin{array}{lrrrrrrrrrrr}N & 4 & 8 & 20 & 0 & 26 & 19 & 16 & 9 & 16 & 4 & 7 \\ \text { PSD } & a & a & a & a & 80 & a & a & a & a & a & a \\ \text { RSD-P } & a & a & a & a & 23 & a & a & a & a & a & a\end{array}$

\section{Bonneville Reservoir}

Northern Pikeminnow

$\begin{array}{lrrrrrrrrrrr}N & 245 & 350 & - & 213 & 378 & 319 & 199 & 169 & 136 & 106 & 40 \\ \text { PSD } & 43 & 61 & - & 44 & 40 & 26 & 24 & 33 & 18 & 40 & 45\end{array}$

Smallmouth Bass

$\begin{array}{lrrrrrrrrrrr}N & 111 & 97 & - & 236 & 332 & 285 & 256 & 239 & 235 & 418 & 573 \\ \text { PSD } & 39 & 48 & - & 26 & 37 & 33 & 58 & 46 & 44 & 40 & 46 \\ \text { RSD-P } & 15 & 20 & - & 10 & 12 & 11 & 14 & 13 & 17 & 19 & 15\end{array}$

Walleye

\begin{tabular}{|c|c|c|c|c|c|c|c|c|c|c|c|}
\hline$N$ & 4 & 7 & - & 2 & 9 & 10 & 15 & 6 & 6 & 2 & 4 \\
\hline PSD & $a$ & $a$ & - & $a$ & $a$ & $a$ & $a$ & $a$ & $a$ & $a$ & $a$ \\
\hline RSD-P & $a$ & $a$ & - & $a$ & $a$ & $a$ & $a$ & $a$ & $a$ & $a$ & $a$ \\
\hline
\end{tabular}


Median relative weight differed significantly $(P<0.01)$ among years for male and female northern pikeminnow (Figure 10). Median relative weight for male and female northern pikeminnow was higher in 2008 than any other year for both below Bonneville Dam and in Bonneville Reservoir.

Median relative weight for smallmouth bass fluctuated moderately below Bonneville Dam and in Bonneville Reservoir (Figure 11). In both reaches, median relative weight was lowest in 1996 and highest in 1994. While relative weight of smallmouth bass was lower in 2008 compared to when previously sampled, the difference was not significant $(P>0.05)$.

Median relative weight for walleye was not significantly different in 2008 than any other year sampled for both below Bonneville Dam $(P=0.75)$ and in Bonneville Reservoir $(P=0.28)$ (Figure 12). The median relative weight in 2008 was slightly higher than when previously sampled below Bonneville Dam and in Bonneville Reservoir. Sample sizes for these areas continue to remain low.

\section{DISCUSSION}

In 2008, system-wide exploitation of northern pikeminnow $\geq 250 \mathrm{~mm}$ FL by the sport-reward fishery $(19.5 \%)$ was the highest in program history. However, system-wide exploitation remains within the target range of 10-20\% (Rieman and Beamesderfer 1990). The trend since program inception has been one of increasing exploitation, and the five highest exploitation rates have all occurred in the last five years. From 1995 to 2003 there has been a negative relationship between river flow and system-wide exploitation rates for northern pikeminnow $\geq 250 \mathrm{~mm} F L$ (Takata and Koloszar 2004). Since 2003 this relationship degraded, suggesting that other factors may be influencing exploitation. We have looked into several factors related to changes in the reward structure and experience of the anglers participating in the sport fishery, but have not identified strong associations with exploitation rates. We will continue to consider possible relationships with increasing exploitation rate.

Previous reports have shown that northern pikeminnow 200-249 $\mathrm{mm}$ FL have been recaptured at a lower rate than larger tagged fish (Takata and Koloszar 2004; Takata et al. 2007; Weaver et al. 2008). From a practical standpoint, the low number of recaptures limited our ability to provide an unbiased estimate of exploitation for this size class, which may preclude their use in systemwide estimates (Styer 2003). Since these smaller fish are included in estimating exploitation rates for all northern pikeminnow $\geq 200 \mathrm{~mm}$ FL, these estimates may be adding bias that could be avoided. For this reason, we recommend using exploitation rates for northern pikeminnow $\geq 250$ $\mathrm{mm}$ FL for describing trends in population exploitation over time.

The 2008 dam-angling fishery accounted for $2.4 \%$ of the total northern pikeminnow harvest. This was a decrease from 3.8\% in 2007 (Weaver et al. 2008) and well below the $11.2 \%$ observed during 1991-1996 (Friesen and Ward 1999). No tagged northern pikeminnow were recovered by the dam anglers in 2008. As in previous years, 


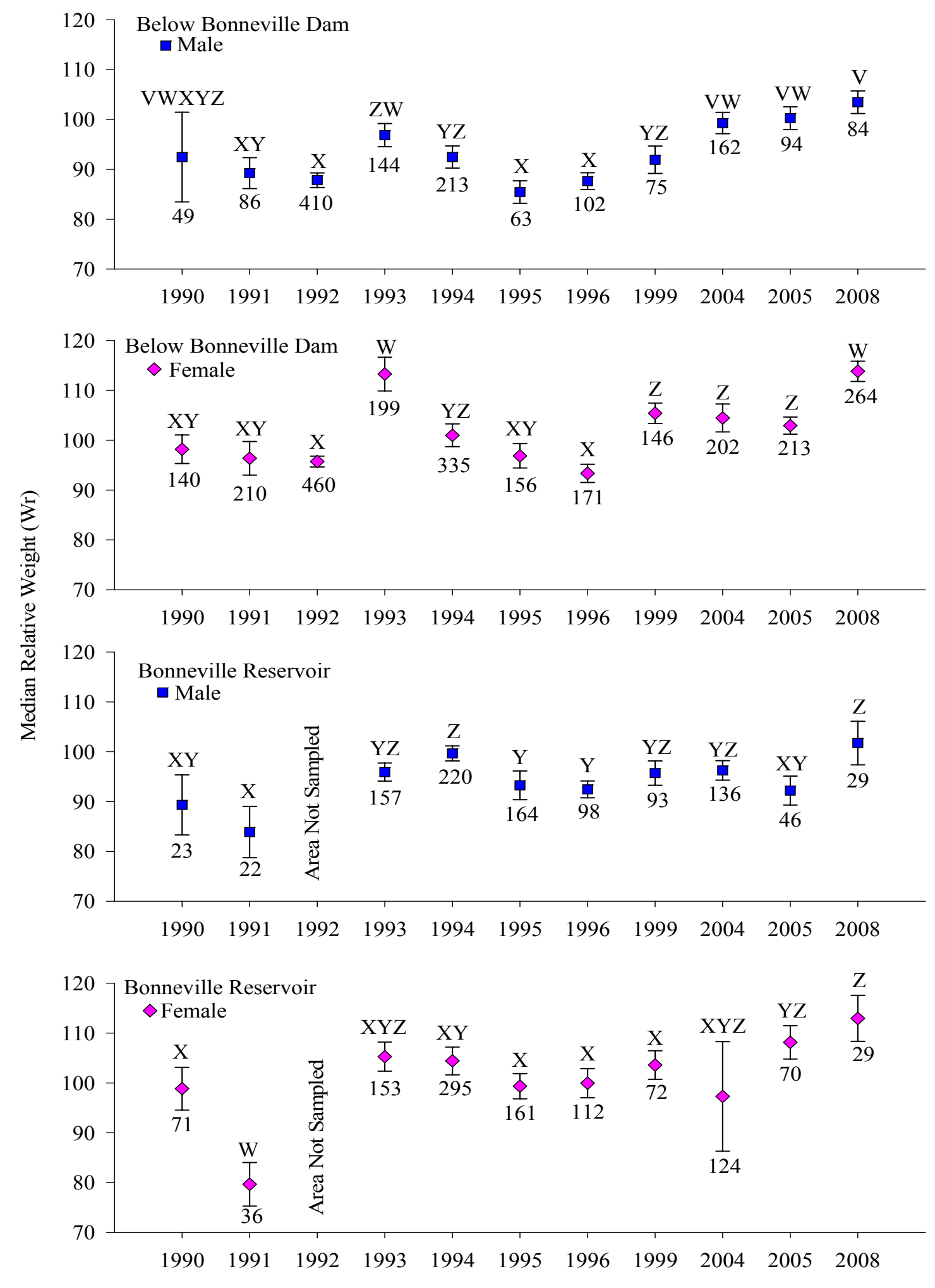

Figure 10. Relative weight of male and female northern pikeminnow below Bonneville Dam and in Bonneville Reservoir, 1990-1996, 1999, 2004, 2005, and 2008. Bars without a letter in common differ significantly $(P<0.05)$; numbers below the bars are the sample size. 


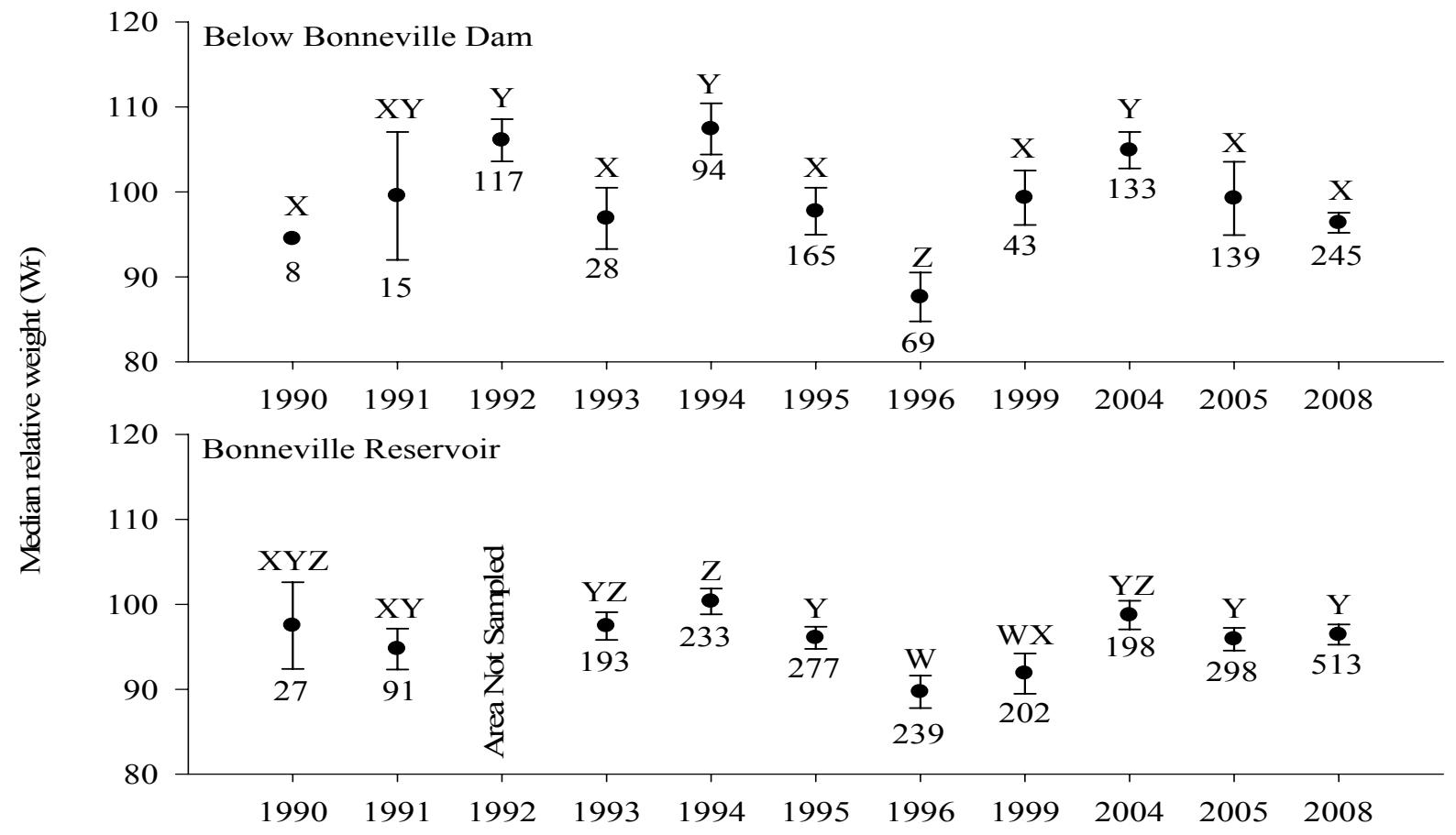

Figure 11. Relative weight of smallmouth bass below Bonneville Dam and in Bonneville Reservoir, 1990-1996, 1999, 2004, 2005, and 2008. Bars without a letter in common differ significantly $(P<0.05)$; numbers below the bars are the sample size.

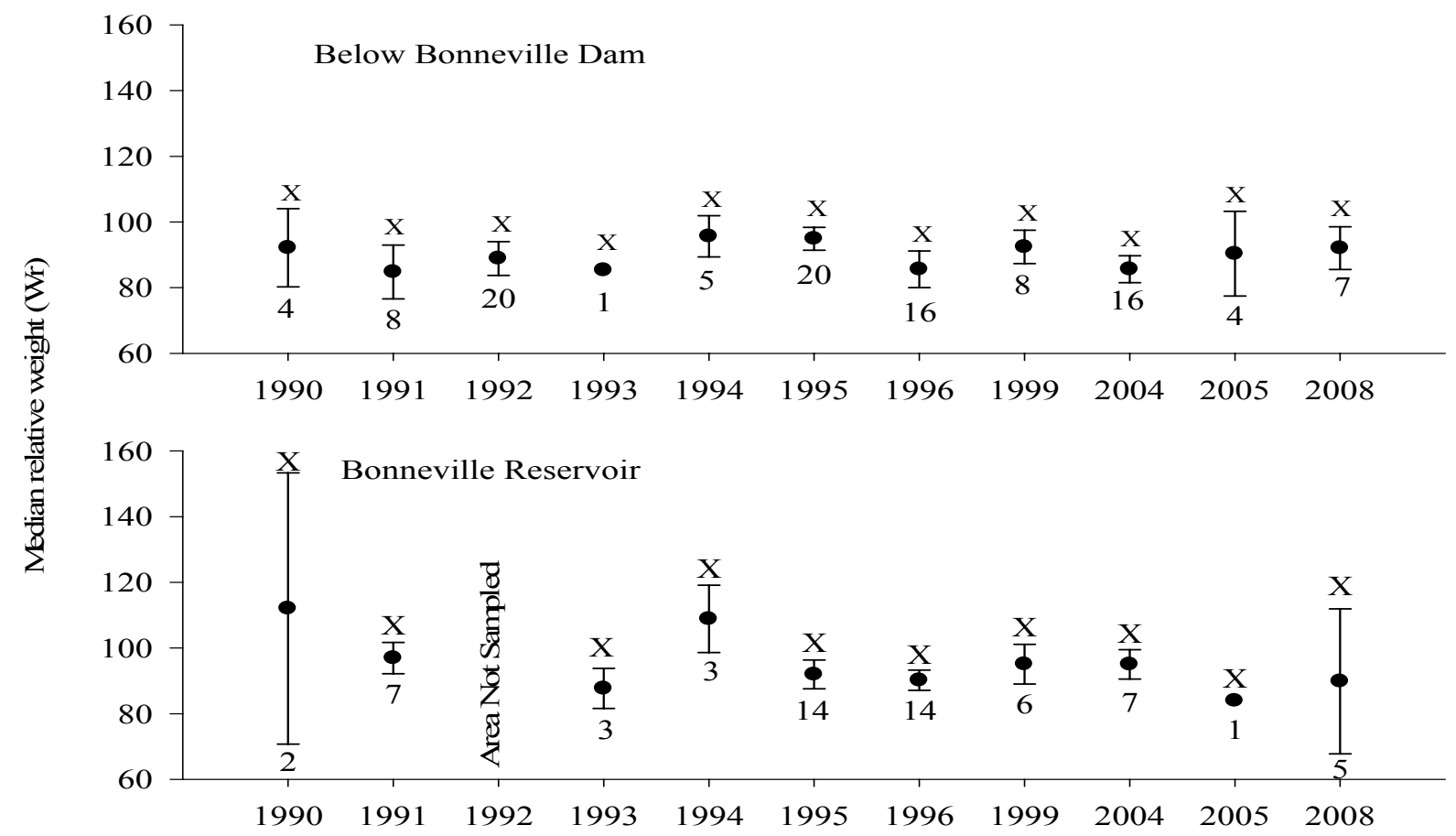

Figure 12. Relative weight of walleye below Bonneville Dam and in Bonneville Reservoir, 1990-1996, 1999, 2004, 2005, and 2008. Bars without a letter in common differ significantly $(P$ $<0.05$ ); numbers below the bars are the sample size. 
northern pikeminnow sampled from the dam-angling fishery in 2008 were larger (median fork length $352 \mathrm{~mm}$ ) than those sampled in the sport-reward fishery $(274 \mathrm{~mm})$. On average, dam anglers may have better opportunity for harvesting larger mature northern pikeminnow than sport anglers (Martinelli and Shively 1997). For this reason we support continued angling from the dams, and will continue to monitor dam-angling activities in 2009.

Reductions in the northern pikeminnow population may improve outmigrating salmonid survival if an equal compensatory response by the remaining northern pikeminnow or other predators does not minimize the benefits (Beamesderfer et al. 1996; Friesen and Ward 1999). An increase in the abundance, population size structure, condition factor, or consumption and predation indices might indicate such a response (Knutsen and Ward 1999). Sustained exploitation should decrease the proportion of large (older) fish to small (younger) fish (Zimmerman et al. 1995), and smaller northern pikeminnow consume fewer salmonids than their larger counterparts (Vigg et al. 1991). Continued monitoring of the fisheries should provide the program with the information needed to identify status of compensatory response being expressed by these populations of fish.

Northern pikeminnow stock density indices appear to be fluctuating in habitats below Bonneville Dam and in Bonneville Reservoir. The observed increasing trend in the proportional stock density may indicate that there is change occurring in the way the population is functioning. Proportional stock densities measured in 2008 were similar to those observed in 1990, which may imply that larger northern pikeminnow are rebounding. Rieman and Beamesderfer (1990) suggested that a decreasing trend in proportional stock density may predict the effect of the sport-reward fishery by qualifying the direction of change in the size structure of northern pikeminnow. Neumann and Allen (2007) indicate that proportional stock density can be high in low density populations. Proportional stock density values in 2008 may also be related to lower abundance index values. Everhart and Youngs (1981) found that overexploited fish populations may show oscillating patterns of year class strength. Changes in northern pikeminnow abundance, year class strength, and size structure may be related to exploitation, thus continued monitoring is need to better understand the fisheries association with the functional dynamics of the population.

Increased northern pikeminnow consumption and predation indices might also be signs of compensation by remaining northern pikeminnow to prolonged exploitation by the Northern Pikeminnow Management Program (Zimmerman and Ward 1999). Although generally lower than previous years, northern pikeminnow consumption and predation indices have increased, relative to recent years, within several localized reaches of the study area (e.g., the lower reaches and tailrace section below Bonneville Dam and the forebay section in Bonneville Reservoir). The percentage of stomach remains identified as salmonids has also increased. The highest northern pikeminnow sport-reward harvests have been Below Bonneville Dam (Winther et al. 2009, this report). Intra-specific competition for home range and forage resources can be harmful to fish populations (Crowder 1990; Byorth and Magee 1998). Based on localized increases in northern pikeminnow consumption in high harvest areas, a localized reduction of intra-specific competition could be occurring, and is possibly a compensatory response by remaining northern pikeminnow. The predation index is composed of two components, consumption and abundance (Ward et al. 1995). Overall, most reductions in northern 
pikeminnow predation below Bonneville Dam and in Bonneville Reservoir can be attributable to changes in abundance; which was generally lower in 2008 than in previous indexing years.

The efficacy of the Northern Pikeminnow Management Program depends on the lack of response by other piscivores in the Columbia Basin to the sustained removal of northern pikeminnow (Ward and Zimmerman 1999). The size structure for the Bonneville Reservoir population of smallmouth bass appears more balanced and stable than the population in the reaches downstream of Bonneville Dam. Since 2005, the proportional stock density values below Bonneville Dam have dropped below 30, which may be an indication of a population that is out of balance (Anderson and Weithman 1978). Carline and Johnson (1984) cautioned against using proportional stock density values alone to evaluate populations, and recommended using relative weight in conjunction with proportional stock density values. The relative weights below Bonneville Dam are not significantly different than many of the previous years even though the proportional stock density values above 30. Within the relatively stable size structure of Bonneville Reservoir smallmouth bass, a shift in age structure may be occurring. The frequency of age 5 fish in our samples has been increasing through time, but it is unclear what role year class strength and recruitment may have played in this observation (Miranda and Hubbard 1994; Van Den Avyle and Hayward 1999). As reported in earlier work (Poe et al. 1991; Zimmerman 1999; Naughton et al. 2004), juvenile salmonids comprised a small but consistent portion of smallmouth bass diets in the Columbia River during 2008, and the primary prey consumed by smallmouth bass continued to be sculpin. Ward and Zimmerman (1999) suggested the first evidence of any response by smallmouth bass would likely be a change in diet. Therefore, smallmouth bass population structure should continue to be monitored to identify any compensatory response related to northern pikeminnow fisheries.

The abundance of walleye below Bonneville Dam and in Bonneville Reservoir is minimal compared to other predators such as northern pikeminnow and smallmouth bass. Given the low number of walleye we have not been able to calculate proportional stock density or relative stock density values. Relative weight values have been stable and are not significantly different in any of the years sampled. Juvenile salmonids have been found to be an important component of lower Columbia River walleye diets (Poe et al. 1991; Vigg et al. 1991; Zimmerman 1999). Takata et al. (2007) found salmonids most often in walleye digestive tracts in The Dalles and John Day reservoirs. In 2008, Salmonids and peamouth chub were the primary fish found in the walleye diets below Bonneville dam and in Bonneville Reservoir. Therefore, the impact walleye predation has on salmonid populations could differ among areas. Further monitoring of walleye population parameters and diets would be prudent.

Previous evaluations of the Northern Pikeminnow Management Program have not detected responses by the predator community to the sustained removal of northern pikeminnow (Ward et al. 1995; Ward and Zimmerman 1999; Zimmerman and Ward 1999). In 2008, we found some indications of possible localized responses to the removal program. Fishery management programs have been described as needing sustained annual sampling to effectively evaluate if a response has occurred (Beamesderfer et al. 1996). Therefore, it is critical to continue monitoring to assess the impact of the Northern Pikeminnow Management Program. 


\section{ACKNOWLEDGEMENTS}

We are grateful to those who worked long hours in the field to collect the data presented in this report. Thanks to Kelsey Adkisson, Jesse Ott, George Reed, Adam Smith, Kevin Stertz, Adam Storch, Peter Susi, and Justin Zweifel. We thank Mark Engelking and Sharon Vendshus, of ODFW, for the use of their laboratory space, as well as Mike Gribble and Ken Frisby for allowing us to park our boats at their facilities. We thank Eric Winther, of WDFW, and his staff for their cooperation and help with project coordination, and Kathleen Moyer for providing PIT tag recovery and Floy FT-4 lock-on loop tag loss information. The U.S. Army Corps of Engineers was very cooperative regarding entry into boat-restricted zones near dams; in particular, we appreciate the assistance of Brad Eby, Tammy Mackey, Jon Rerecich, Scott Ross, Dwane Watsek, and Miro Zyndol.

This project is funded by the Bonneville Power Administration (project number 1990-077-00); the COTR is John Skidmore. Christine Mallette of ODFW and Russell Porter of PSMFC (Pacific States Marine Fish Commission) administered the contract. 


\section{REFERENCES}

Anderson, R. O. 1980. Proportional stock density (PSD) and relative weight $\left(\mathrm{W}_{\mathrm{r}}\right)$ : interpretive indices for fish populations and communities. Pages 27-33 in S. Gloss and B. Shupp, editors. Practical fisheries management: more with less in the 1980s. New York Chapter American Fisheries Society, Bethesda, MD.

Anderson, R. O., and R. M. Neumann. 1996. Length, weight, and associated structural indices. Pages 447-482 in B. R. Murphy and D. W. Willis, editors. Fisheries Techniques, $2^{\text {nd }}$ edition. American Fisheries Society, Bethesda, Maryland.

Anderson, R. O., and A. S. Weithman. 1978. The concept of balance for coolwater fish populations. American Fisheries Society Special Publication 11:371-381.

Beamesderfer, R. C., and B. E. Rieman. 1988. Size selectivity and bias in estimates of population statistics of smallmouth bass, walleye, and northern squawfish in a Columbia River reservoir. North American Journal of Fisheries Management 8:505-510.

Beamesderfer, R. C., D. L. Ward, and A. A. Nigro. 1996. Evaluation of the biological basis for a predator control program on northern squawfish (Ptychocheilus oregonensis) in the Columbia and Snake rivers. Canadian Journal of Fisheries and Aquatic Sciences 53:2898-2908.

Byorth, P. A., and J. P. Magee. 1998. Competitive interactions between arctic grayling and brook trout in the Big Hole River drainage, Montana. Transactions of the American Fisheries Society 127:921-931.

Carline, R. F., and B. L. Johnson 1984. Estimation and Interpretation of Proportional Stock Density for Fish Populations in Ohio Impoundments. North American Journal of Fisheries Management 4(2):139-154

Collis, K., D. D. Roby, D. P. Craig, S. Adamany, J. Y. Adkins, and D. E. Lyons. 2002. Colony size and diet composition of piscivorous water birds on the Lower Columbia River: Implications for losses of juvenile salmonids to avian predation. Transactions of the American Fisheries Society 131:537-550.

Crowder, L. B. 1990. Community ecology. Pages 609-632 in C. B. Schreck and P. B. Moyle, editors. Methods for Fish Biology. American Fisheries Society, Bethesda, Maryland.

DeVries, D. R., and R.V. Frie. 1996. Determination of age and growth. Pages 483-512 in B. R. Murphy and D. W. Willis, editors. Fisheries Techniques, $2^{\text {nd }}$ edition. American Fisheries Society, Bethesda, Maryland.

Everhart, W. H., and W. D. Youngs. 1981. Principles of fishery science, $2^{\text {nd }}$ edition. Cornell University Press, Ithaca, New York. 
FPC (Fish Passage Center). 2005. Smolt Monitoring Program Metadata. Available: www.fpc.org/documents/metadata/FPC_SMP_Metadata.html (May 2005)

Friesen, T. A., and D. L. Ward. 1999. Management of northern pikeminnow and implications for juvenile salmonid survival in the lower Columbia and Snake rivers. North American Journal of Fisheries Management 19:406-420.

Gabelhouse, D. W., Jr. 1984. A length-categorization system to assess fish stocks. North American Journal of Fisheries Management 4:273-285.

Jones, T. A., J. A. Koloszar, M. J. Reesman, T. A. Friesen, and H. K Takata. 2005. Development of a system-wide predator control program: fisheries evaluation. Oregon Department of Fish and Wildlife, Contract Number DE-B1719-94BI24514. 2003 Annual Report to the Bonneville Power Administration, Portland, Oregon.

Knutsen, C. J., and D. L. Ward. 1999. Biological characteristics of northern pikeminnow in the Lower Columbia and Snake Rivers before and after sustained exploitation. Transactions of the American Fisheries Society 128:1008-1019.

Kolander, C. J., D. W. Willis, and B. R. Murphy. 1993. Proposed revision of the standard weights $\left(\mathrm{W}_{\mathrm{s}}\right)$ equation for smallmouth bass. North American Journal of Fisheries Management 13:398-400.

Long, C. W., and F. J. Ossiander. 1974. Survival of coho salmon fingerlings passing through a perforated bulkhead in an empty turbine bag and through flow deflectors (with and without dentates) on the spillways of Lower Monumental Dam, Snake River, April-May 1973. Final Report (Contract DACW68-84-H-0034) to U.S. Army Corps of Engineers, Portland, Oregon.

Martinelli, T. L., and R. S. Shively. 1997. Seasonal distribution, movements and habitat associations of northern squawfish in two lower Columbia River reservoirs. Regulated Rivers: Research and Management 6, pp 543-556, Nov-Dec 1997.

Miranda, L. E., and W. D. Hubbard. 1994. Length-dependent winter survival and lipid composition of Age-0 largemouth bass in Bay Springs Reservoir, Mississippi. Transactions of the American Fisheries Society 123:80-87.

Murphy, B. R., M. L. Brown, and T. A. Springer. 1990. Evaluation of the relative weight $\left(W_{r}\right)$ index, with new applications to walleye. North American Journal of Fisheries Management 10:85-97.

Naughton, G. P., D. H. Bennet, and K. B. Newman. 2004. Predation on juvenile salmonids by smallmouth bass in the Lower Granite Reservoir system, Snake River. North American Journal of Fisheries Management 24:534-544. 
Nehlsen, W., J. E. Williams, and J. A. Lichatowich. 1991. Pacific salmon at the crossroads: stocks at risk from California, Oregon, Idaho, and Washington. Fisheries 16:4-21.

Neumann, R. S. and M. S. Allen. 2007. Size structure. Pages 375-421 in C. S. Guy and M. L. Brown, editors. Analysis and interpretation of freshwater fisheries data. American fisheries Society, Bethesda, Maryland.

Parker, R. M., M. P. Zimmerman, and D. L. Ward. 1995. Variability in biological characteristics of northern squawfish in the lower Columbia and Snake rivers. Transactions of the American Fisheries Society 124:335-346.

Poe, T. P., H. C. Hansel, S. Vigg, D. E. Palmer, and L. A. Prendergast. 1991. Feeding of predaceous fishes on out-migrating juvenile salmonids in the John Day Reservoir, Columbia River. Transactions of the American Fisheries Society 120:405-420.

Porter, R. G. 2009. Northern Pikeminnow Sport Reward Payments-2008. Annual report to the Bonneville Power Administration, Project 199007700, Portland, Oregon.

Raymond, H. L. 1988. Effects of hydroelectric development and fisheries enhancement on spring and summer Chinook salmon and steelhead in the Columbia River basin. North American Journal of Fisheries Management 8:1-24.

Ricker, W. E. 1975. Computation and interpretation of biological statistics of fish populations. Fisheries Research Board of Canada Bulletin 191.

Rieman, B. E., and R. C. Beamesderfer. 1990. Dynamics of a northern squawfish population and the potential to reduce predation on juvenile salmonids in a Columbia River reservoir. North American Journal of Fisheries Management 10:228-241.

Rieman, B. E., R. C. Beamesderfer, S. Vigg, and T. P. Poe. 1991. Estimated loss of juvenile salmonids to predation by northern squawfish, walleyes, and smallmouth bass in John Day Reservoir, Columbia River. Transactions of the American Fisheries Society 120:448-458.

Styer, P. 2003. Statistical consulting report to review computational methods in the northern pikeminnow management program. Report to the Oregon Department of Fish and Wildlife, Clackamas.

Takata, H. K., and J. A. Koloszar. 2004. Development of a system-wide predator control program: fisheries evaluation. Oregon Department of Fish and Wildlife, Contract Number DE-B1719-94BI24514. 2003 Annual Report to the Bonneville Power Administration, Portland, Oregon.

Takata, H. K., M. J. Reesman, G. E. Reed, L. D. Layng, and T. A. Jones. 2007. Development of a system-wide predator control program: indexing and fisheries evaluation. Oregon 
Department of Fish and Wildlife, Contract Number DE-B1719-94BI24514. 2006 Annual Report to the Bonneville Power Administration, Portland, Oregon.

Van Den Avyle, M. J., and R. S. Hayward. 1999. Dynamics of exploited fish populations. Pages 127-166 in C. C. Kohler and W. A. Hubert, editors. Inland Fisheries Management in North America, $2^{\text {nd }}$ edition. American Fisheries Society, Bethesda, Maryland.

Vigg, S., T. P. Poe, L. A. Prendergast, and H. C. Hansel. 1991. Rates of consumption of juvenile salmonids and alternative prey fish by northern squawfish, walleyes, smallmouth bass, and channel catfish in John Day Reservoir, Columbia River. Transactions of the American Fisheries Society 120:421-438.

Ward, D. L., J. H. Petersen, and J. J. Loch. 1995. Index of predation on juvenile salmonids by northern squawfish in the lower and middle Columbia River and in the lower Snake River. Transactions of the American Fisheries Society 124:321-334.

Ward, D. L., and M. P. Zimmerman. 1999. Response of smallmouth bass to sustained removals of northern pikeminnow in the lower Columbia and Snake Rivers. Transactions of the American Fisheries Society 128:1020-1035.

Weaver, M. H., H. K. Takata, M. J. Reesman, L. D. Layng, G. E. Reed, and T. A. Jones. 2008. Development of a system-wide predator control program: fisheries evaluation. Oregon Department of Fish and Wildlife, Contract Number DE-B1719-94BI24514. 2007 Annual Report to the Bonneville Power Administration, Portland, Oregon.

Willis, D. W., K. D. McCloskey, and D. W. Gabelhouse, Jr. 1985. Calculation of stock density indices based on adjustments for efficiency of gill-net mesh size. North American Journal of Fisheries Management 5:126-137.

Winther, E. C., J. D. Hone, P. V. Dunlap, and K. C. Moyer. 2009. Implementation of the Northern Pikeminnow Sport-Reward Fishery in the Columbia and Snake Rivers. Annual report to the Bonneville Power Administration, Project 199007700, Portland, Oregon.

Wismar, R. C., J. E. Smith, B. A. McIntosh, H. W. Li, G. H. Reeves, and J. R. Sedell. 1994. A history of resource use and disturbance in riverine basins of eastern Oregon and Washington (early 1800s-1900s). Northwest Science 68(Special Issue):1-35.

Zimmerman, M. P. 1999. Food habits of smallmouth bass, walleyes, and northern pikeminnow in the lower Columbia River Basin during outmigration of juvenile anadromous salmonids. Transactions of the American Fisheries Society 128:995-1007.

Zimmerman, M. P., C. Knutsen, D. L. Ward, and K. Anderson. 1995. Development of a system-wide predator control program: Indexing and fisheries evaluation. Oregon Department of Fish and Wildlife, Contract number DE-AI79-90BP07084. 1993 Annual Report to the Bonneville Power Administration, Portland, Oregon. 
Zimmerman, M. P., and D. L. Ward. 1999. Index of predation on juvenile salmonids by northern pikeminnow in the lower Columbia River basin, 1994-1996. Transactions of the American Fisheries Society 128:995-1007.

Zimmerman, M.P., T. A. Friesen, D. L. Ward, and H. K. Takata. 2000. Development of a system-wide predator control program: indexing and fisheries evaluation. Oregon Department of Fish and Wildlife, Contract Number DE-B1719-94BI24514. 1999 Annual Report to the Bonneville Power Administration, Portland, Oregon. 


\section{Appendix A}

Sampling Effort and Timing in the Lower Columbia and Snake Rivers 
Appendix Table A-1. Dates of 2008 sampling weeks.

\begin{tabular}{|c|c|}
\hline Sampling Week & Dates \\
\hline 10 & 3 March-9 March \\
\hline 11 & 10 March-16 March \\
\hline 12 & 17 March-23 March \\
\hline 13 & 24 March-30 March \\
\hline 14 & 31 March-6 April \\
\hline 15 & 7 April-13 April \\
\hline 16 & 14 April-20 April \\
\hline 17 & 21 April-27 April \\
\hline 18 & 28 April-4 May \\
\hline 19 & 5 May-11 May \\
\hline 20 & 12 Мay-18 May \\
\hline 21 & 19 May-25 May \\
\hline 22 & 26 May-1 June \\
\hline 23 & 2 June- 8 June \\
\hline 24 & 9 June-15 June \\
\hline 25 & 16 June-22 June \\
\hline 26 & 23 June-29 June \\
\hline 27 & 30 June- 6 July \\
\hline 28 & 7 July-13 July \\
\hline 29 & 14 July-20 July \\
\hline 30 & 21 July-27 July \\
\hline 31 & 28 July-3 August \\
\hline 32 & 4 August-10 August \\
\hline 33 & 11 August- 17 August \\
\hline 34 & 18 August-24 August \\
\hline 35 & 25 August- 31 August \\
\hline 36 & 1 September-7 September \\
\hline 37 & 8 September-14 September \\
\hline 38 & 15 September-21 September \\
\hline 39 & 22 September-28 September \\
\hline 40 & 29 September-5 October \\
\hline 41 & 6 October- 12 October \\
\hline 42 & 13 October-19 October \\
\hline
\end{tabular}


Appendix Table A-2. Sampling effort (number of 15-minute electrofishing runs) for biological indexing in the lower Columbia and Snake rivers, 1990-1996, 1999, and 2004-2007. rkm = river kilometer and $-=$ area not sampled.

\begin{tabular}{|c|c|c|c|c|c|c|c|c|c|c|c|c|c|}
\hline $\begin{array}{l}\text { Area/reservoir, } \\
\text { reach }\end{array}$ & 1990 & 1991 & 1992 & 1993 & 1994 & 1995 & 1996 & 1999 & 2004 & 2005 & 2006 & 2007 & 2008 \\
\hline \multicolumn{14}{|c|}{ Below Bonneville Dam } \\
\hline rkm 114-121 & - & - & 68 & - & 36 & 45 & 43 & 44 & 22 & 48 & - & - & 48 \\
\hline rkm 172-178 & - & - & 65 & - & 33 & 36 & 35 & 47 & 31 & 48 & - & - & 48 \\
\hline rkm 190-197 & - & - & 64 & - & 43 & 40 & 40 & 40 & 32 & 48 & - & - & 48 \\
\hline Tailrace & 39 & - & 60 & 25 & 35 & 24 & 31 & 29 & 55 & 82 & - & - & 78 \\
\hline \multicolumn{14}{|l|}{ Bonneville } \\
\hline Forebay & 47 & - & - & 35 & 97 & 79 & 80 & 62 & 35 & 101 & - & - & 87 \\
\hline Mid-reservoir & 52 & - & - & 28 & 84 & 45 & 57 & 57 & 35 & 58 & - & - & 69 \\
\hline Tailrace & 52 & - & - & 31 & 68 & 80 & 69 & 71 & 43 & 74 & - & - & 73 \\
\hline \multicolumn{14}{|l|}{ The Dalles } \\
\hline Forebay & 62 & - & - & 31 & 92 & 62 & 59 & - & - & - & 78 & - & - \\
\hline Mid-reservoir & - & - & - & - & - & - & - & - & - & - & 95 & - & - \\
\hline Tailrace & 56 & - & - & 26 & 48 & 35 & 31 & 71 & 5 & - & 74 & - & - \\
\hline \multicolumn{14}{|l|}{ John Day } \\
\hline Forebay & 56 & 61 & 68 & 44 & 91 & 75 & 75 & 52 & 28 & - & 75 & - & - \\
\hline Mid-reservoir & 61 & 58 & 62 & 43 & 43 & 94 & 94 & - & 15 & - & 80 & - & - \\
\hline Tailrace & 55 & 59 & 64 & 46 & 74 & 80 & 80 & 62 & 51 & - & 76 & - & - \\
\hline \multicolumn{14}{|l|}{ Ice Harbor } \\
\hline Forebay & - & 57 & - & - & - & - & - & - & - & - & - & 37 & - \\
\hline Mid-reservoir & - & 59 & - & - & - & - & - & - & - & - & - & 40 & - \\
\hline Tailrace & - & 67 & - & - & - & - & - & - & - & - & - & 40 & - \\
\hline \multicolumn{14}{|c|}{ Lower Monumental } \\
\hline Forebay & - & 66 & - & - & - & - & - & - & - & - & - & 40 & - \\
\hline Mid-reservoir & - & 61 & - & - & - & - & - & - & - & - & - & 36 & - \\
\hline Tailrace & - & 56 & - & - & 44 & 46 & 32 & 14 & 30 & - & - & 37 & - \\
\hline \multicolumn{14}{|l|}{ Little Goose } \\
\hline Forebay & - & 61 & - & - & - & - & - & - & - & - & - & 40 & - \\
\hline Mid-reservoir & - & 55 & - & - & - & - & - & - & - & - & - & 24 & - \\
\hline Tailrace & - & 57 & - & - & 39 & 40 & 37 & 29 & 30 & - & - & 20 & - \\
\hline \multicolumn{14}{|l|}{ Lower Granite } \\
\hline rkm 222-228 & - & 55 & - & - & 85 & 89 & 89 & 75 & 34 & - & - & 96 & - \\
\hline
\end{tabular}




\section{Appendix B}

Exploitation Rates for Northern Pikeminnow 
Appendix Table B-1. Exploitation (\%) of northern pikeminnow 200-249 mm FL, $\geq 250 \mathrm{~mm}$ FL, and both groups combined ( $\geq 200 \mathrm{~mm}$ FL) for the sport-reward fishery, 2003-2008. $a=$ no exploitation rate calculated $(n<4)$ and "-" = area not sampled.

\begin{tabular}{|c|c|c|c|c|c|c|}
\hline $\begin{array}{c}\text { Size group, } \\
\text { Area } \\
\end{array}$ & 2003 & 2004 & 2005 & 2006 & 2007 & 2008 \\
\hline \multicolumn{7}{|l|}{ 200-249 mm FL } \\
\hline Below Bonneville Dam & $a$ & $a$ & $a$ & 9.6 & $a$ & $a$ \\
\hline Bonneville & $a$ & $a$ & $a$ & 6.7 & $a$ & $a$ \\
\hline The Dalles & $a$ & $a$ & $a$ & $a$ & $a$ & $a$ \\
\hline John Day & $a$ & $a$ & $a$ & $a$ & $a$ & $a$ \\
\hline McNary & $a$ & $a$ & $a$ & $a$ & $a$ & $a$ \\
\hline Little Goose & - & - & - & 17.4 & $a$ & 4.8 \\
\hline Lower Granite & $a$ & $a$ & $a$ & $a$ & $a$ & $a$ \\
\hline All areas combined & $a$ & 10.9 & $a$ & 9.9 & $a$ & 5.7 \\
\hline \multicolumn{7}{|l|}{$\geq 250 \mathrm{~mm} \mathrm{FL}$} \\
\hline Below Bonneville Dam & 13.6 & 20.1 & 23.1 & 15.6 & 19.4 & 22.2 \\
\hline Bonneville & 16.7 & 9.3 & 8.2 & 13.7 & 11.1 & 10.5 \\
\hline The Dalles & $a$ & $a$ & 18.0 & 25.3 & $a$ & 15.0 \\
\hline John Day & $a$ & $a$ & $a$ & $a$ & $a$ & $a$ \\
\hline McNary & 8.2 & $a$ & 13.0 & 11.2 & 7.5 & 16.8 \\
\hline Little Goose & - & - & - & 26.3 & $a$ & 21.7 \\
\hline Lower Granite & $a$ & 23.8 & $a$ & $a$ & 17.3 & 9.2 \\
\hline All areas combined & 13.0 & 18.5 & 19.0 & 17.1 & 17.8 & 19.5 \\
\hline \multicolumn{7}{|c|}{ Both groups combined ( $\geq 200 \mathrm{~mm}$ FL) } \\
\hline Below Bonneville Dam & 11.8 & 18.8 & 21.6 & 14.6 & 18.4 & 20.6 \\
\hline Bonneville & 11.0 & 11.7 & 8.0 & 10.5 & 9.6 & 9.6 \\
\hline The Dalles & $a$ & $a$ & 14.9 & 22.4 & $a$ & 13.8 \\
\hline John Day & $a$ & $a$ & $a$ & $a$ & $a$ & $a$ \\
\hline McNary & 6.6 & $a$ & 9.6 & 10.7 & 5.9 & 14.1 \\
\hline Little Goose & - & - & - & 20.0 & 35.0 & 8.3 \\
\hline Lower Granite & $a$ & 19.6 & $a$ & $a$ & 11.8 & 4.1 \\
\hline All areas combined & 10.5 & 17.0 & 16.3 & 14.6 & 15.3 & 14.8 \\
\hline
\end{tabular}


Appendix Table B-2. System-wide weekly exploitation rates of northern pikeminnow $\geq 200 \mathrm{~mm}$ FL for the sport-reward fishery in 2008. Dashes indicate either no tagging effort, no recapture effort, or no exploitation calculated.

\begin{tabular}{|c|c|c|c|c|}
\hline Sampling Week & Tagged & Recaptured & At-Large & Exploitation $^{a}(\%)$ \\
\hline 10 & 5 & - & - & - \\
\hline 11 & - & - & 5 & 一 \\
\hline 12 & - & - & 5 & 一 \\
\hline 13 & - & - & 5 & - \\
\hline 14 & 24 & - & 5 & - \\
\hline 15 & 36 & 一 & 29 & 一 \\
\hline 16 & 46 & - & 65 & - \\
\hline 17 & 220 & 一 & 111 & - \\
\hline 18 & 95 & 一 & 331 & - \\
\hline 19 & 81 & 2 & 426 & 0.5 \\
\hline 20 & 10 & 4 & 505 & 0.8 \\
\hline 21 & 13 & 3 & 511 & 0.6 \\
\hline 22 & 24 & 3 & 521 & 0.6 \\
\hline 23 & 157 & 2 & 542 & 0.4 \\
\hline 24 & 197 & 10 & 697 & 1.5 \\
\hline 25 & 97 & 8 & 884 & 1.0 \\
\hline 26 & - & 13 & 973 & 1.4 \\
\hline 27 & - & 14 & 960 & 1.5 \\
\hline 28 & - & 10 & 946 & 1.1 \\
\hline 29 & - & 6 & 936 & 0.7 \\
\hline 30 & - & 2 & 930 & 0.2 \\
\hline 31 & - & 2 & 928 & 0.2 \\
\hline 32 & - & 2 & 926 & 0.2 \\
\hline 33 & - & 6 & 924 & 0.7 \\
\hline 34 & - & 1 & 918 & 0.1 \\
\hline 35 & - & 6 & 917 & 0.7 \\
\hline 36 & - & 2 & 911 & 0.2 \\
\hline 37 & - & 5 & 909 & 0.6 \\
\hline 38 & - & 6 & 904 & 0.7 \\
\hline 39 & - & 1 & 898 & 0.1 \\
\hline 40 & - & 5 & 897 & 0.6 \\
\hline 41 & - & 3 & 892 & 0.4 \\
\hline 42 & - & 0 & 889 & 0.0 \\
\hline Total & 1,005 & 116 & 889 & 14.8 \\
\hline
\end{tabular}

${ }^{a}$ Exploitation rates adjusted for tag loss (5.0\%). 


\section{Appendix C}

Biological Evaluation of Northern Pikeminnow, Smallmouth Bass, and Walleye below Bonneville Dam and in Bonneville Reservoir 
Appendix Table C-1. Catch per 15-minute electrofishing run (CPUE) of northern pikeminnow $\geq 250 \mathrm{~mm}$ fork length captured during biological indexing of the lower Columbia River in 1990, 1992-1996, 1999, 2004, 2005 and 2008. $\mathrm{rkm}=$ river kilometer, BRZ = boat restricted zone, $-=$ area not sampled.

\begin{tabular}{lrrrrrrrrrrr}
\hline $\begin{array}{l}\text { Area, } \\
\text { Reach }\end{array}$ & 1990 & 1992 & 1993 & 1994 & 1995 & 1996 & 1999 & 2004 & 2005 & 2008 \\
\hline Below Bonneville Dam & & & & & & & & & & & \\
$\quad$ rkm 114-121 & - & 1.3 & - & 1.0 & 0.9 & 0.8 & 0.6 & 0.7 & 0.7 & 0.8 \\
rkm 172-178 & - & 1.6 & - & 1.8 & 1.4 & 1.5 & 0.9 & 0.6 & 0.7 & 0.6 \\
rkm 190-197 & - & 2.4 & - & 1.7 & 1.1 & 1.3 & 1.4 & 1.1 & 0.6 & 0.4 \\
Tailrace & 5.8 & 3.4 & 9.6 & 2.9 & 2.2 & 2.8 & 3.5 & 1.6 & 0.9 & 1.4 \\
Tailrace BRZ & 13.7 & 12.9 & 14.5 & 18.9 & 4.6 & 5.8 & - & 11.8 & 8.1 & 12.1 \\
& & & & & & & & & & \\
Bonneville Reservoir & & & & & & & & & & \\
Forebay & 5.7 & - & 2.2 & 2.4 & 2.4 & 1.3 & 1.0 & 0.9 & 0.7 & 0.2 \\
Mid-reservoir & 2.1 & - & 1.2 & 0.7 & 1.0 & 0.7 & 0.3 & 0.3 & 0.3 & 0.1 \\
Tailrace & 0.5 & - & 1.1 & 0.6 & 1.1 & 0.8 & 0.8 & 1.7 & 0.3 & 0.3 \\
Tailrace BRZ & 5.5 & - & 1.5 & 6.8 & - & - & - & - & - & - \\
\hline
\end{tabular}


APPENDIX TABLE C-2. Abundance index values for northern pikeminnow $\geq 250 \mathrm{~mm}$ fork length in the lower Columbia River, 1990, 1992-1996, 1999, 2004, 2005, and 2008. rkm = river kilometer; BRZ $=$ boat-restricted zone, and $-=$ not sampled.

\begin{tabular}{lcrrrrrrrrr}
\hline $\begin{array}{l}\text { Area, } \\
\text { Reach }\end{array}$ & 1990 & 1992 & 1993 & 1994 & 1995 & 1996 & 1999 & 2004 & 2005 & 2008 \\
\hline Below Bonneville Dam & & & & & & & & & & \\
rkm 114-121 & - & 20.1 & - & 15.4 & 14.5 & 12.2 & 9.8 & 10.6 & 11.2 & 13.2 \\
rkm 172-178 & - & 20.5 & - & 23.2 & 17.4 & 18.7 & 11.8 & 8.1 & 9.2 & 7.8 \\
rkm 190-197 & - & 30.4 & - & 22.1 & 14.2 & 16.4 & 17.4 & 13.3 & 8.2 & 4.5 \\
Tailrace & 4.5 & 2.7 & 7.6 & 2.3 & 1.8 & 2.2 & 2.7 & 1.3 & 0.6 & 1.1 \\
Tailrace BRZ & 3.0 & 2.8 & 3.2 & 4.1 & 1.0 & 1.3 & - & 2.6 & 1.8 & 2.6 \\
& & & & & & & & & & \\
Bonneville Reservoir & & & & & & & & & & \\
Forebay & 5.5 & - & 2.1 & 2.3 & 2.3 & 1.3 & 1.0 & 0.9 & 0.7 & 0.2 \\
Mid-reservoir & 15.1 & - & 8.5 & 5.0 & 7.4 & 4.9 & 2.2 & 2.3 & 1.9 & 0.4 \\
Tailrace & 0.4 & - & 0.8 & 0.5 & 0.8 & 0.7 & 1.1 & 1.3 & 0.2 & 0.2 \\
Tailrace BRZ & 0.9 & - & 0.2 & 1.1 & - & - & - & - & - & - \\
\hline
\end{tabular}


Appendix Table C-3. Spring relative density of smallmouth bass $\geq 200 \mathrm{~mm}$ fork length in the lower Columbia River, 1990-1996, 1999, 2004, 2005, and 2008. River kilometer = rkm; dashes indicate areas not sampled. Relative density is mean transformed catch $\left(\log _{10}(\right.$ catch +1$\left.)\right)$ per 15 minute electrofishing run.

\begin{tabular}{|c|c|c|c|c|c|c|c|c|c|c|c|}
\hline $\begin{array}{l}\text { Area, } \\
\text { Reach }\end{array}$ & 1990 & 1991 & 1992 & 1993 & 1994 & 1995 & 1996 & 1999 & 2004 & 2005 & 2008 \\
\hline \multicolumn{12}{|c|}{ Below Bonneville Dam } \\
\hline rkm 114-121 & - & - & 0.0 & - & 0.0 & $<0.1$ & 0.0 & 0.0 & 0.0 & 0.1 & 0.1 \\
\hline rkm 172-178 & - & - & 0.2 & - & 0.2 & 0.5 & 0.3 & 0.1 & 0.3 & 0.1 & 0.3 \\
\hline rkm 190-197 & - & - & 0.1 & - & 0.1 & 0.4 & 0.1 & $<0.1$ & 0.1 & 0.2 & 0.2 \\
\hline Tailrace & - & - & 0.1 & - & 0.1 & 0.4 & 0.1 & 0.1 & 0.3 & 0.2 & 0.3 \\
\hline \multicolumn{12}{|c|}{ Bonneville Reservoir } \\
\hline Forebay & $<0.1$ & $<0.1$ & - & 0.1 & $<0.1$ & 0.1 & 0.1 & 0.1 & 0.2 & 0.2 & 0.3 \\
\hline Mid-reservoir & 0.3 & $<0.1$ & - & 0.1 & 0.3 & 0.3 & 0.2 & 0.1 & - & 0.3 & 0.1 \\
\hline Tailrace & 0.3 & 0.3 & - & 0.7 & 0.5 & 0.4 & 0.6 & 0.4 & 0.5 & 0.3 & 0.5 \\
\hline
\end{tabular}

Appendix Table C-4. Summer relative density of smallmouth bass $\geq 200 \mathrm{~mm}$ fork length in the lower Columbia River, 1990-1996, 1999, 2004, 2005, and 2008. River kilometer = rkm; dashes indicate areas not sampled. Relative density is mean transformed catch $\left(\log _{10}(\operatorname{catch}+1)\right)$ per 15 minute electrofishing run.

\begin{tabular}{lcccccccccccc}
\hline \begin{tabular}{l} 
Area, \\
\multicolumn{1}{l}{ Reach }
\end{tabular} & 1990 & 1991 & 1992 & 1993 & 1994 & 1995 & 1996 & 1999 & 2004 & 2005 & 2008 \\
\hline Below Bonneville Dam & & & & & & & & & & \\
rkm 114-121 & - & - & $<0.1$ & - & 0.1 & $<0.1$ & $<0.1$ & 0.0 & $<0.1$ & $<0.1$ & 0.1 \\
rkm 172-178 & - & - & 0.1 & - & 0.2 & 0.2 & 0.1 & 0.1 & 0.1 & 0.2 & 0.3 \\
rkm 190-197 & - & - & 0.1 & - & 0.1 & 0.2 & 0.1 & 0.1 & 0.2 & 0.2 & 0.3 \\
Tailrace & - & - & 0.2 & - & 0.1 & 0.2 & 0.1 & 0.2 & 0.1 & 0.1 & 0.2 \\
& & & & & & & & & & & \\
Bonneville Reservoir & & & & & & & & & & \\
Forebay & 0.1 & 0.0 & - & 0.1 & $<0.1$ & 0.1 & $<0.1$ & 0.2 & - & 0.2 & 0.3 \\
Mid-reservoir & 0.1 & 0.1 & - & 0.2 & 0.2 & 0.1 & 0.1 & 0.1 & 0.3 & 0.3 & 0.4 \\
\multicolumn{2}{l}{ Tailrace } & 0.2 & 0.4 & - & 0.4 & 0.4 & 0.5 & 0.2 & 0.4 & 0.4 & 0.2 & 0.5 \\
\hline
\end{tabular}

Appendix Table C-5. Spring relative density of walleye $\geq 200 \mathrm{~mm}$ fork length in the lower Columbia River, 1990-1996, 1999, 2004, 2005, and 2008. River kilometer $=\mathrm{rkm}$; dashes indicate areas not sampled. Relative density is mean transformed catch $\left(\log _{10}(\mathrm{catch}+1)\right)$ per 15 minute electrofishing run.

$\begin{array}{llllllllllll}\text { Area, } & 1990 & 1991 & 1992 & 1993 & 1994 & 1995 & 1996 & 1999 & 2004 & 2005 & 2008\end{array}$ 


\begin{tabular}{|c|c|c|c|c|c|c|c|c|c|c|c|}
\hline \multicolumn{12}{|l|}{ Reach } \\
\hline \multicolumn{12}{|c|}{ Below Bonneville Dam } \\
\hline rkm 114-121 & - & - & 0.0 & - & 0.0 & 0.0 & 0.0 & 0.0 & 0.0 & 0.0 & 0.0 \\
\hline rkm 172-178 & - & - & - & - & $<0.1$ & 0.1 & $<0.1$ & 0.0 & 0.0 & 0.0 & 0.0 \\
\hline rkm 190-197 & - & - & 0.1 & - & $<0.1$ & 0.0 & $<0.1$ & $<0.1$ & 0.0 & 0.0 & 0.0 \\
\hline Tailrace & 0.0 & 0.1 & - & $<0.1$ & 0.2 & 0.1 & 0.1 & 0.1 & 0.1 & $<0.1$ & $<0.1$ \\
\hline \multicolumn{12}{|c|}{ Bonneville Reservoir } \\
\hline Forebay & 0.0 & - & - & 0.0 & $<0.1$ & 0.0 & 0.0 & 0.0 & 0.0 & 0.0 & 0.0 \\
\hline Mid-reservoir & 0.0 & - & - & 0.0 & $<0.1$ & $<0.1$ & $<0.1$ & $<0.1$ & - & 0.0 & $<0.1$ \\
\hline Tailrace & 0.0 & 0.1 & 一 & 0.1 & $<0.1$ & $<0.1$ & 0.1 & $<0.1$ & 0.1 & $<0.1$ & $<0.1$ \\
\hline
\end{tabular}

Appendix Table C-6. Summer relative density of walleye $\geq 200 \mathrm{~mm}$ fork length in the lower Columbia River, 1990-1996, 1999, 2004, 2005, and 2008. River kilometer $=\mathrm{rkm}$; dashes indicate areas not sampled. Relative density is mean transformed catch $\left(\log _{10}(\right.$ catch +1$\left.)\right)$ per 15 minute electrofishing run.

\begin{tabular}{lccccccccccc}
\hline $\begin{array}{l}\text { Area, } \\
\text { Reach }\end{array}$ & 1990 & 1991 & 1992 & 1993 & 1994 & 1995 & 1996 & 1999 & 2004 & 2005 & 2008 \\
\hline $\begin{array}{l}\text { Below Bonneville Dam } \\
\text { rkm 114-121 }\end{array}$ & - & - & 0.0 & - & 0.0 & 0.0 & 0.0 & 0.0 & 0.0 & 0.0 & 0.0 \\
rkm 172-178 & - & - & $<0.1$ & - & 0.1 & $<0.1$ & 0.0 & 0.0 & 0.0 & 0.0 & $<0.1$ \\
rkm 190-197 & - & - & $<0.1$ & - & $<0.1$ & $<0.1$ & $<0.1$ & $<0.1$ & $<0.1$ & 0.0 & 0.0 \\
Tailrace & 0.1 & $<0.1$ & $<0.1$ & 0.0 & $<0.1$ & 0.1 & 0.1 & 0.1 & 0.1 & 0.0 & $<0.1$ \\
& & & & & & & & & & & \\
Bonneville Reservoir & & & & & & & & & & \\
Forebay & 0.0 & 0.0 & - & 0.0 & 0.0 & 0.0 & 0.0 & 0.0 & - & 0.0 & 0.0 \\
Mid-reservoir & 0.0 & 0.0 & - & $<0.1$ & 0.0 & $<0.1$ & $<0.1$ & $<0.1$ & $<0.1$ & $<0.1$ & $<0.1$ \\
Tailrace & $<0.1$ & $<0.1$ & - & 0.0 & 0.0 & $<0.1$ & $<0.1$ & $<0.1$ & $<0.1$ & 0.0 & 0.0 \\
\hline
\end{tabular}


Appendix Table C-7. Number $(N)$ of northern pikeminnow, smallmouth bass, and walleye digestive tracts examined from the lower Columbia River in 2008, and percent that contained food, fish, and salmonids (Sal).

\begin{tabular}{|c|c|c|c|c|c|c|c|c|c|c|c|c|}
\hline \multirow{3}{*}{$\begin{array}{l}\text { Season, } \\
\text { Area }\end{array}$} & \multicolumn{4}{|c|}{ Northern pikeminnow } & \multirow{2}{*}{\multicolumn{4}{|c|}{$\frac{\text { Smallmouth bass }}{\text { Percent }}$}} & \multirow{2}{*}{\multicolumn{4}{|c|}{$\frac{\text { Walleye }}{\text { Percent }}$}} \\
\hline & \multirow[b]{2}{*}{$N$} & \multicolumn{3}{|c|}{ Percent } & & & & & & & & \\
\hline & & Food & Fish & Sal & $N$ & \multirow[t]{2}{*}{ Food } & \multirow[t]{2}{*}{ Fish } & Sal & $N$ & \multirow[t]{2}{*}{ Food } & \multirow[t]{2}{*}{ Fish } & Sal \\
\hline \multicolumn{9}{|l|}{ Spring } & & & & \\
\hline Below Bonneville Dam & 46 & 67 & 35 & 17 & 36 & 81 & 25 & 3 & 0 & - & - & 一 \\
\hline Bonneville Dam tailrace & 126 & 54 & 44 & 37 & 75 & 84 & 25 & 1 & 2 & 50 & 50 & 50 \\
\hline Bonneville Reservoir & 45 & 33 & 20 & 20 & 226 & 90 & 28 & 4 & 4 & 100 & 100 & 75 \\
\hline All areas combined & 217 & 53 & 37 & 29 & 337 & 88 & 27 & 3 & 6 & 83 & 83 & 67 \\
\hline \multicolumn{13}{|l|}{ Summer } \\
\hline Below Bonneville Dam & 30 & 73 & 37 & 20 & 78 & 82 & 50 & 23 & 1 & 100 & 100 & 0 \\
\hline Bonneville Dam tailrace & 130 & 56 & 33 & 12 & 25 & 88 & 44 & 4 & 4 & 75 & 75 & 25 \\
\hline Bonneville Reservoir & 20 & 45 & 5 & 5 & 287 & 91 & 26 & 4 & 1 & 100 & 100 & 0 \\
\hline All areas combined & 180 & 58 & 31 & 13 & 390 & 89 & 32 & 8 & 6 & 83 & 83 & 17 \\
\hline
\end{tabular}

Appendix Table C-8. Percent species composition (with count of identifiable fish in parentheses) of fish consumed by northern pikeminnow, smallmouth bass, and walleye in the lower Columbia River, 2008. BBD = below Bonneville Dam, BON = Bonneville Reservoir, and $n=$ number of samples examined.

\begin{tabular}{|c|c|c|c|c|c|c|}
\hline \multirow[b]{2}{*}{ Taxa } & \multicolumn{2}{|c|}{ Northern pikeminnow } & \multicolumn{2}{|c|}{ Smallmouth bass } & \multicolumn{2}{|c|}{ Walleye } \\
\hline & $\begin{array}{l}\text { BBD } \\
n=114\end{array}$ & $\begin{array}{l}\mathrm{BON} \\
\mathrm{n}=10\end{array}$ & $\begin{array}{l}\text { BBD } \\
n=56\end{array}$ & $\begin{array}{l}\mathrm{BON} \\
\mathrm{n}=93\end{array}$ & $\begin{array}{l}\mathrm{BBD} \\
\mathrm{n}=4\end{array}$ & $\begin{array}{l}\mathrm{BON} \\
\mathrm{n}=5\end{array}$ \\
\hline Oncorhynchus spp. & $65(76)$ & $100(10)$ & $34(21)$ & $19(20)$ & $33(2)$ & $43(3)$ \\
\hline Cottus spp. & $25(29)$ & 0 & $44(27)$ & $45(48)$ & 0 & 0 \\
\hline Lampetra spp. & $1(1)$ & 0 & 0 & 0 & 0 & 0 \\
\hline Alosa sapidissima & $1(1)$ & 0 & 0 & 0 & 0 & 0 \\
\hline Cyprinidae & 0 & 0 & 0 & $1(1)$ & 0 & 0 \\
\hline Mylocheilus caurinus & $6(7)$ & 0 & $6(4)$ & $15(16)$ & $50(3)$ & $43(3)$ \\
\hline Ptychocheilus oregonensis & 0 & 0 & 0 & $6(6)$ & 0 & $14(1)$ \\
\hline Richardsonius balteatus & 0 & 0 & 0 & $2(2)$ & 0 & 0 \\
\hline Catostomus spp. & 0 & 0 & $2(1)$ & $4(4)$ & $17(1)$ & 0 \\
\hline Ictaluridae $e^{a}$ & 0 & 0 & 0 & $1(1)$ & 0 & 0 \\
\hline Gasterosteus aculeatus & $2(3)$ & 0 & $11(7)$ & $1(1)$ & 0 & 0 \\
\hline Micropterus spp. & 0 & 0 & $3(2)$ & $6(6)$ & 0 & 0 \\
\hline
\end{tabular}

${ }^{a}$ Combined both Ameiurus spp. and Ictalurus spp. 
Appendix Table C-9. Spring consumption indices for northern pikeminnow $\geq 250 \mathrm{~mm}$ fork length in the lower Columbia River, 1990, 1992-1996, 1999, 2004, 2005, and 2008. BRZ = boat-restricted zone; $\mathrm{rkm}=$ river kilometer; $-=$ area not sampled, and $a=$ no consumption index calculated $(n \leq 5)$.

\begin{tabular}{|c|c|c|c|c|c|c|c|c|c|c|}
\hline $\begin{array}{l}\text { Area, } \\
\text { Reach }\end{array}$ & 1990 & 1992 & 1993 & 1994 & 1995 & 1996 & 1999 & 2004 & 2005 & 2008 \\
\hline \multicolumn{11}{|c|}{ Below Bonneville Dam } \\
\hline rkm 114-121 & - & 0.5 & - & 0.5 & 0.5 & 0.4 & 0.8 & 0.2 & 0.2 & 0.8 \\
\hline rkm 172-178 & - & 1.0 & - & 1.1 & 0.2 & 0.1 & 0.4 & 0.3 & 0.0 & 0.0 \\
\hline rkm 190-197 & - & 1.1 & - & 1.5 & 0.7 & 0.4 & 0.4 & 0.1 & 0.5 & 0.0 \\
\hline Tailrace & 1.2 & 0.5 & 0.8 & 3.2 & 0.8 & 0.4 & 0.1 & 0.3 & 0.4 & 1.0 \\
\hline Tailrace BRZ & 2.7 & 1.0 & 1.1 & 0.6 & 1.7 & 0.6 & - & 1.0 & 1.6 & 0.9 \\
\hline \multicolumn{11}{|c|}{ Bonneville Reservoir } \\
\hline Forebay & 0.6 & - & 0.7 & 0.2 & 0.3 & 0.0 & 0.0 & 0.5 & 0.3 & 1.3 \\
\hline Mid-reservoir & 0.0 & - & 0.0 & 0.2 & 0.0 & 0.1 & 0.6 & - & $a$ & $a$ \\
\hline Tailrace & 0.3 & - & 0.0 & 0.0 & 0.2 & 0.0 & 0.2 & 0.0 & 1.5 & 0.6 \\
\hline Tailrace BRZ & 2.3 & - & - & - & - & - & - & $a$ & - & - \\
\hline
\end{tabular}

APPENDiX TABLE C-10. Appendix Table B-8. Summer consumption indices for northern pikeminnow $\geq 250 \mathrm{~mm}$ fork length in the lower Columbia River, 1990, 1992-1996, 1999, 2004, 2005 and 2008. BRZ = boat-restricted zone; $\mathrm{rkm}=$ river kilometer; $-=$ area not sampled, and $a$ $=$ no consumption index calculated $(n \leq 5)$.

\begin{tabular}{|c|c|c|c|c|c|c|c|c|c|c|}
\hline $\begin{array}{l}\text { Area, } \\
\text { Reach }\end{array}$ & 1990 & 1992 & 1993 & 1994 & 1995 & 1996 & 1999 & 2004 & 2005 & 2008 \\
\hline \multicolumn{11}{|c|}{ Below Bonneville Dam } \\
\hline rkm 114-121 & - & 0.3 & - & 1.8 & 1.5 & 0.0 & 1.0 & 0.4 & 1.2 & 1.7 \\
\hline rkm 172-178 & - & 1.3 & - & 1.5 & 0.4 & 0.0 & 0.0 & 0.7 & 0.3 & 1.2 \\
\hline rkm 190-197 & - & 1.9 & - & 0.4 & 1.2 & 0.0 & 0.5 & 0.2 & 0.6 & 0.4 \\
\hline Tailrace & 0.5 & 2.1 & 1.2 & 0.4 & 0.9 & 0.6 & 0.2 & 0.2 & 0.0 & 0.3 \\
\hline Tailrace BRZ & 5.5 & 7.8 & 1.0 & 2.1 & 1.3 & 3.1 & - & 4.0 & 3.8 & 1.0 \\
\hline \multicolumn{11}{|c|}{ Bonneville Reservoir } \\
\hline Forebay & 1.8 & - & 0.5 & 0.3 & 0.0 & 0.3 & 0.0 & - & 0.0 & $a$ \\
\hline Mid-reservoir & 0.0 & - & 0.0 & 0.0 & 0.0 & 0.0 & 0.0 & 0.0 & $a$ & $a$ \\
\hline Tailrace & $a$ & - & 0.0 & 0.0 & 0.8 & 0.0 & 0.3 & 1.1 & $a$ & $a$ \\
\hline Tailrace BRZ & 0.8 & - & 1.0 & 3.2 & - & - & - & $a$ & - & - \\
\hline
\end{tabular}


Appendix Table C-11. Spring consumption indices for smallmouth bass $\geq 200 \mathrm{~mm}$ fork length in the lower Columbia River, 1990, 1992-1996, 1999, 2004, 2005 and 2008. rkm = river kilometer; $-=$ area not sampled, and $a=$ no consumption index calculated $(n \leq 5)$.

\begin{tabular}{|c|c|c|c|c|c|c|c|c|c|c|}
\hline $\begin{array}{l}\text { Area, } \\
\text { Reach }\end{array}$ & 1990 & 1992 & 1993 & 1994 & 1995 & 1996 & 1999 & 2004 & 2005 & 2008 \\
\hline \multicolumn{11}{|c|}{ Below Bonneville Dam } \\
\hline rkm 114-121 & - & $a$ & - & $a$ & $a$ & - & - & $a$ & $a$ & $a$ \\
\hline rkm 172-178 & - & 0.1 & - & 0.0 & 0.1 & 0.0 & $a$ & 0.0 & 0.3 & $a$ \\
\hline rkm 190-197 & - & $a$ & - & 0.3 & 0.0 & 0.0 & $a$ & 0.2 & 0.1 & $<0.1$ \\
\hline Tailrace & - & $a$ & - & 0.0 & 0.0 & 0.0 & $a$ & 0.0 & 0.1 & $<0.1$ \\
\hline \multicolumn{11}{|c|}{ Bonneville Reservoir } \\
\hline Forebay & $a$ & - & $a$ & $a$ & 0.1 & 0.0 & 0.0 & 0.0 & 0.1 & $<0.1$ \\
\hline Mid-reservoir & $a$ & - & $a$ & 0.0 & 0.1 & 0.0 & $a$ & - & 0.0 & 0.0 \\
\hline Tailrace & 0.0 & - & 0.0 & 0.0 & 0.0 & 0.0 & $<0.1$ & 0.0 & $<0.1$ & $<0.1$ \\
\hline
\end{tabular}

Appendix Table C-12. Summer consumption indices for smallmouth bass $\geq 200 \mathrm{~mm}$ fork length in the lower Columbia River, 1990, 1992-1996, 1999, 2004, 2005 and 2008. rkm = river kilometer; $-=$ area not sampled, and $a=$ no consumption index calculated $(n \leq 5)$.

\begin{tabular}{lclllllllll}
\hline $\begin{array}{l}\text { Area, } \\
\text { Reach }\end{array}$ & 1990 & 1992 & 1993 & 1994 & 1995 & 1996 & 1999 & 2004 & 2005 & 2008 \\
\hline $\begin{array}{l}\text { Below Bonneville Dam } \\
\text { rkm 114-121 }\end{array}$ & - & $a$ & - & 0.0 & $a$ & $a$ & - & $a$ & $a$ & 0.8 \\
rkm 172-178 & - & 0.0 & - & 0.2 & 0.3 & $a$ & 0.0 & 0.0 & 0.2 & 0.5 \\
rkm 190-197 & - & 0.4 & - & 0.3 & 0.8 & 0.0 & 0.0 & 0.2 & 0.6 & 0.6 \\
Tailrace & - & $a$ & - & 0.0 & 0.0 & $a$ & 0.0 & 0.4 & 0.1 & 0.1 \\
& & & & & & & & & & \\
Bonneville Reservoir & & & & & & & & & \\
Forebay & $a$ & - & $a$ & 0.4 & 0.0 & 0.0 & 0.2 & - & 0.1 & 0.1 \\
Mid-reservoir & $a$ & - & 0.0 & 0.0 & 0.0 & 0.0 & 0.0 & 0.0 & 0.1 & 0.1 \\
Tailrace & $a$ & - & 0.0 & 0.1 & 0.1 & 0.0 & 0.0 & 0.0 & 0.1 & $<0.1$ \\
\hline
\end{tabular}


Appendix Table C-13. Spring predation indices for northern pikeminnow $\geq 250 \mathrm{~mm}$ fork length in the lower Columbia River, 1990, 1992-1996, 1999, 2004, 2005, and 2008. BRZ = boat restricted zone; $\mathrm{rkm}=$ river kilometer; $-=$ not sampled, and $a=$ no predation index calculated $(n \leq 5)$.

\begin{tabular}{lcccccccccc}
\hline $\begin{array}{l}\text { Area, } \\
\text { Reach }\end{array}$ & 1990 & 1992 & 1993 & 1994 & 1995 & 1996 & 1999 & 2004 & 2005 & 2008 \\
\hline \multicolumn{2}{l}{ Below Bonneville Dam } & & & & & & & & & \\
rkm 114-121 & - & 10.4 & - & 8.0 & 7.3 & 4.9 & 7.5 & 1.8 & 2.0 & 10.4 \\
rkm 172-178 & - & 20.9 & - & 26.2 & 3.5 & 1.9 & 5.0 & 2.5 & 0.0 & 0.0 \\
rkm 190-197 & - & 34.4 & - & 33.3 & 9.9 & 6.6 & 7.1 & 1.5 & 4.4 & 0.0 \\
Tailrace & 5.5 & 1.4 & 6.1 & 7.4 & 1.4 & 0.9 & 0.4 & 0.3 & 0.3 & 1.1 \\
Tailrace BRZ & 8.0 & 2.8 & 3.5 & 2.5 & 1.7 & 0.8 & - & 2.5 & 2.8 & 2.4 \\
& & & & & & & & & & \\
Bonneville Reservoir & & & & & & & & & \\
Forebay & 3.3 & - & 1.5 & 0.3 & 0.7 & 0.0 & 0.0 & 0.5 & 0.2 & 0.3 \\
Mid-reservoir & 0.0 & - & 0.0 & 1.0 & 0.0 & 0.5 & 1.3 & - & 2.2 & $a$ \\
Tailrace & 0.1 & - & 0.0 & 0.0 & 0.2 & 0.0 & 0.2 & 0.0 & 0.3 & 0.1 \\
Tailrace BRZ & 2.0 & - & - & - & 1.5 & - & - & - & - & - \\
\hline
\end{tabular}

Appendix Table C-14. Summer predation indices for northern pikeminnow $\geq 250 \mathrm{~mm}$ fork length in the lower Columbia River, 1990, 1992-1996, 1999, 2004, 2005, and 2008. BRZ = boat-restricted zone; $\mathrm{rkm}=$ river kilometer; $-=$ not sampled, and $a=$ no predation index calculated $(n \leq 5)$.

\begin{tabular}{lcccccccccc}
\hline $\begin{array}{l}\text { Area, } \\
\text { Reach }\end{array}$ & 1990 & 1992 & 1993 & 1994 & 1995 & 1996 & 1999 & 2004 & 2005 & 2008 \\
\hline \multicolumn{2}{l}{ Below Bonneville Dam } & & & & & & & & & \\
rkm 114-121 & - & 6.2 & - & 27.3 & 14.5 & 0.0 & 9.4 & 4.7 & 13.3 & 22.0 \\
rkm 172-178 & - & 27.0 & - & 35.0 & 7.0 & 0.0 & 0.0 & 5.8 & 3.1 & 9.4 \\
rkm 190-197 & - & 57.8 & - & 9.5 & 17.0 & 0.0 & 9.5 & 2.3 & 5.1 & 1.7 \\
Tailrace & 2.3 & 5.7 & 9.1 & 1.0 & 1.6 & 1.3 & 0.6 & 0.3 & 0.0 & 0.3 \\
Tailrace BRZ & 16.4 & 21.9 & 3.2 & 8.9 & 1.2 & 4.0 & - & 10.2 & 6.8 & 2.4 \\
& & & & & & & & & & \\
Bonneville Reservoir & & & & & & & & & \\
Forebay & 9.9 & - & 1.1 & 0.6 & 0.0 & 0.4 & 0.0 & - & 0.0 & $a$ \\
Mid-reservoir & 0.0 & - & 0.0 & 0.0 & 0.0 & 0.0 & 0.0 & 0.0 & $a$ & $a$ \\
Tailrace & 0.0 & - & 0.0 & 0.0 & 0.6 & 0.0 & 0.3 & 1.4 & $a$ & $a$ \\
Tailrace BRZ & 0.7 & - & 0.2 & 3.5 & - & - & - & - & - & - \\
\hline
\end{tabular}


Appendix Table C-15. Spring and summer predation indices for smallmouth bass $\geq 200 \mathrm{~mm}$ fork length in the lower Columbia River, 2004, 2005 and 2008. BRZ = boat-restricted zone; rkm $=$ river kilometer; $-=$ area not sampled, and $a=$ no predation index calculated $(n \leq 5)$.

\begin{tabular}{|c|c|c|c|c|c|c|}
\hline \multirow{2}{*}{$\begin{array}{l}\text { Area, } \\
\text { Reach }\end{array}$} & \multicolumn{3}{|l|}{ Spring } & \multicolumn{3}{|c|}{ Summer } \\
\hline & 2004 & 2005 & 2008 & 2004 & 2005 & 2008 \\
\hline \multicolumn{7}{|c|}{ Below Bonneville Dam } \\
\hline rkm 114-121 & $a$ & $a$ & $a$ & $a$ & $a$ & 0.3 \\
\hline rkm 172-178 & 0.0 & 2.1 & $a$ & 0.0 & 1.7 & 3.0 \\
\hline rkm 190-197 & 2.2 & 0.6 & 0.3 & 2.2 & 5.3 & 5.0 \\
\hline Tailrace $^{b}$ & 0.0 & 0.0 & $<0.1$ & 0.2 & 0.1 & 0.1 \\
\hline \multicolumn{7}{|c|}{ Bonneville Reservoir } \\
\hline Forebay & 0.0 & 0.1 & 0.1 & - & 0.2 & 0.1 \\
\hline Mid-reservoir & - & 0.0 & 0.0 & 0.0 & 1.0 & 1.1 \\
\hline Tailrace $^{\mathrm{b}}$ & 0.0 & $<0.1$ & $<0.1$ & 0.0 & 0.1 & 0.1 \\
\hline
\end{tabular}

${ }^{b}$ Tailrace and tailrace BRZ numbers combined.

Appendix Table C-16. Spring and summer predation indices for northern pikeminnow $\geq 250 \mathrm{~mm}$ fork length and smallmouth bass $\geq 200 \mathrm{~mm}$ fork length in the lower Columbia River, 2008. BRZ $=$ boat-restricted zone; $\mathrm{rkm}=$ river kilometer; $-=$ area not sampled, and $a=$ no predation index calculated $(n \leq 5)$.

\begin{tabular}{|c|c|c|c|c|}
\hline \multirow{2}{*}{$\begin{array}{l}\text { Area, } \\
\text { Reach }\end{array}$} & \multicolumn{2}{|c|}{ Northern pikeminnow } & \multicolumn{2}{|c|}{ Smallmouth bass } \\
\hline & Spring & Summer & Spring & Summer \\
\hline \multicolumn{5}{|c|}{ Below Bonneville Dam } \\
\hline rkm 114-121 & 10.4 & 22.0 & $a$ & 0.3 \\
\hline rkm 172-178 & 0.0 & 9.4 & $a$ & 3.0 \\
\hline rkm 190-197 & 0.0 & 1.7 & 0.3 & 5.0 \\
\hline Tailrace & 1.1 & 0.3 & $<0.1$ & $<0.1$ \\
\hline Tailrace BRZ & 2.4 & 2.4 & 0.0 & 0.0 \\
\hline \multicolumn{5}{|c|}{ Bonneville Reservoir } \\
\hline Forebay & 0.3 & $a$ & 0.1 & 0.1 \\
\hline Mid-reservoir & $a$ & $a$ & 0.0 & 1.1 \\
\hline Tailrace & 0.1 & $a$ & $<0.1$ & 0.1 \\
\hline Tailrace BRZ & - & - & - & - \\
\hline
\end{tabular}




\section{Report D}

2008 Dam Angling Season Report

\section{Prepared by}

U.S. Department of Agriculture Animal \& Plant Health Inspection Service Wildlife Services 
March, 2008 


\section{Methods}

Manpower used -We utilized a 5 person angling crew 40 hrs a week plus administrative oversight

Fishing locations -John Day and The Dalles tailrace pools were fished during this season with efforts split between the two projects.

Angling techniques/gear -A variety of baits, lures and techniques were used in an effort to maximize catch rates. The following is a brief list of utilized methods and their results.

Natural Baits- Worms, dead minnows, crickets. These baits were moderately successful all season long and in periods of sluggish fish behavior they outshined artificial baits. Keeping the bait fresh and on the hook was difficult when summer temperatures rose and fish became aggressive. Natural bait involved rigging time between fish resulting in time out of the water. Worms and minnows worked best early and late in the season.

Soft Plastic Tube Baits- These baits are a soft plastic in the shape of a tube. The tube is closed on one end and open on the other with fingers cut into the open end. They look like a squid and come in a variety of colors. They can be weighted with the addition of an egg sinker inside the tube or a sinker on a dropper line to get them down to the level of the fish. These baits were most effective during an active or wide open bite when the fish were aggressively feeding. A variety of colors were tried with the favorite colors being greens, reds, and off color browns all with some degree of metallic flake in them. As the fish stack up behind the dams they can be caught on the surface early and late in the day, but tended to go deeper as the sun rose. When properly rigged this type of bait is good for several fish without needed to be re-rigged, which saves angling time. It doesn't produce as well as the naturals if the fish are lethargic. In an active bite it will out fish the naturals.

Soft Plastic Worm Baits- These are just like the name implies, they are soft plastic worm like baits. We had success similar to the tube baits with these. They tend to be a little longer and a double hook set up is needed to optimize their fish catching abilities. This can be detrimental in active bite conditions as it takes longer to tie up two hooks and there is a slight chance the extra hook could snag the angler if a fish is thrashing about. A single hooked tube will outperform a worm generally, due to the bait being in the water a greater percentage of time. This lure does not work well for non aggressive fish or in times of colder water temperatures.

Soft Plastic Swim baits- These can come in any variety of shapes and resemble swimming vertebrates and invertebrates alike, such as fish, salamanders, frogs and leaches. Some may have a hard lip to impart action but many do not. Limited experimentation with different shapes yielded no greater success than with the soft plastic tubes or worms. Most experimentation focused on minnow-like baits. They seem to tear more easily and lose their functionality earlier than other plastic which still perform okay with a lost finger/tentacle. A good application of this lure may be when the "resident" fish are wise to a heavily fished pattern or lure. Casting in a new look or look similar to natural bait may trigger reaction strikes. Salmon/shad colors worked the best for us. 
Wooden plugs- These balsa wood plugs imitate a wounded minnow. These worked well on surface fish during warmer periods of the season. They are easily suspended for a pause and retrieve technique which triggered strikes when fish get finicky. Due to cost they are not economically feasible as a mainstay. They are also difficult to fish deep for midday fish.

Metal Lures- We tried spoons and spinners in this category. Both produced well on surface fish mid-season, but using them at depth was hard. They are a variety lure used as catch rates slow in a given area and the fish need a change of pace. Not a "go to" lure but did have times where it was an effective alternative. Spinners worked better than spoons.

\section{Results}

A. The Dalles

1. Fishing Effort - 1080 hours

2. Catch- 1400 Pikeminnow

3. By catch -85 fish (see table for species breakdown)

4. Tagged Fish- 0

5. Size Data-Refer to ODFW data

\begin{tabular}{|l|l|l|l|l|}
\hline Location & Hours & \# of Pikeminnow & By-catch total & Tagged Fish \\
\hline The Dalles & 1080 & 1400 & 85 & 0 \\
\hline
\end{tabular}

\begin{tabular}{|l|l|l|l|l|l|}
\hline $\begin{array}{l}\text { By catch } \\
\text { Species }\end{array}$ & Smallmouth Bass & Sturgeon & Walleye & Catfish & Other \\
\hline $\mathrm{N}=85$ & 30 & 25 & 0 & 6 & 24 \\
\hline
\end{tabular}

B. John Day

1. Fishing Effort - 1005 hours

2. Catch- 2428 Pikeminnow

3. By catch -118 fish (see table for species breakdown)

4. Tagged Fish-1

5. Size Data- Refer to ODFW data

\begin{tabular}{|l|l|l|l|l|}
\hline Location & Hours & \# of Pikeminnow & By-catch total & Tagged Fish \\
\hline John Day & 1005 & 2428 & 118 & 1 \\
\hline
\end{tabular}

\begin{tabular}{|l|l|l|l|l|l|}
\hline Species & Smallmouth Bass & Sturgeon & Walleye & Catfish & Other \\
\hline $\mathrm{N}=154$ & 62 & 36 & 12 & 8 & 0 \\
\hline
\end{tabular}




\section{Discussion}

The first week of the season the water and turbines where running so strong we could not effectively get to the bottom of the river, where the fish were located, despite using 4 and 5 ounce sinkers. As the "run off" slowed so did the turbines. We then used 3-4 oz of weight and started to effectively catch fish in good numbers. By the fifth week the run off had started to slow and the water temp rose. We began to catch fish in good numbers. Most of our effort during the first 5 weeks was concentrated at The Dalles (692 hrs) compared to (168 hrs) at John Day. We spent more time at The Dalles because the turbine passage was significantly less than at John Day, making it more productive to fish at The Dalles. During this time frame we attempted to fish our "go to" spots (the Ice/trash sluiceway) at The Dalles and the Navigation Lock at John Day, but again due to high water and $24 \mathrm{hr}$ spill our efforts were hampered. We were also told that we had to have a "safety person" watching the others while we fished from the Navigation Lock cutting our crew to 4. The safety person was to watch only he could not fish. At week six we started to catch better numbers of fish at both dams, so we split the crew (2 at The Dalles and 3 at John Day). We soon discovered that at the end of week six we were catching twice as many fish at John Day than at The Dalles so weeks seven through thirteen we concentrated all our efforts at John Day. Towards the end of the project we tried splitting the crews up again with no real noticeable difference in catch.

Once again the best time of the day to catch fish was the first couple of hours in the morning and some good success right before dark. Overall the "spill" had a considerably negative effect on our fishing efforts this year. Cold water temps and high flows made the fishing tough. We tried to vary our fishing times throughout the day and evening, but the $24 \mathrm{hr}$ spill continued to hamper our efforts.

\section{Suggestions for future operations}

In order to capitalize on the most productive fishing times it is recommended that the removal season starts May $15^{\text {th }}$ and goes through August $15^{\text {th }}$, with some time given before and after these dates for training, security clearance issues, project clean-up, etc.

For safety reasons and ease of splitting the crews and effort between the dams an additional fisherman should be added to the crew. 